\title{
Crucible-Scale Active Vitrification Testing of a Hanford Envelope C Tank 241-AN-102 Sample
}

by

C. L. Crawford

Westinghouse Savannah River Company

Savannah River Site

Aiken, South Carolina 29808

T. B. Calloway

This paper was prepared in connection with work done under the above contract number with the U. S. Department of Energy. By acceptance of this paper, the publisher and/or recipient acknowledges the U.S. Government's right to retain a nonexclusive, royalty-free license in and to any copyright covering this paper, along with the right to reproduce and to authorize others to reproduce all or part of the copyrighted paper. 
This document was prepared in conjunction with work accomplished under Contract No. DE-AC09-96SR18500 with the U. S. Department of Energy.

\section{DISCLAIMER}

This report was prepared as an account of work sponsored by an agency of the United States Government. Neither the United States Government nor any agency thereof, nor any of their employees, makes any warranty, express or implied, or assumes any legal liability or responsibility for the accuracy, completeness, or usefulness of any information, apparatus, product or process disclosed, or represents that its use would not infringe privately owned rights. Reference herein to any specific commercial product, process or service by trade name, trademark, manufacturer, or otherwise does not necessarily constitute or imply its endorsement, recommendation, or favoring by the United States Government or any agency thereof. The views and opinions of authors expressed herein do not necessarily state or reflect those of the United States Government or any agency thereof.

This report has been reproduced directly from the best available copy.

Available for sale to the public, in paper, from: U.S. Department of Commerce, National Technical Information Service, 5285 Port Royal Road, Springfield, VA 22161, phone: (800) 553-6847, fax: (703) 605-6900

email: orders@ntis.fedworld.gov

online ordering: http://www.ntis.gov/help/index.asp

Available electronically at http://www.osti.gov/bridge

Available for a processing fee to U.S. Department of Energy and its contractors, in paper, from: U.S. Department of Energy, Office of Scientific and Technical Information, P.O. Box 62, Oak Ridge, TN 37831-0062,

phone: (865)576-8401,

fax: (865)576-5728

email: $\underline{\text { reports@ adonis.osti.gov }}$ 
KEYWORDS:

\section{Crucible-Scale Active Vitrification Testing Envelope C, Tank 241-AN-102 (U)}

\section{Author(s)}

C. L. Crawford, 773-41A

D. M. Ferrara, 773-43A

R. F. Schumacher, 773-43A

N. E. Bibler, 773-A

Publication Date: June 15, 2001

Westinghouse Savannah River Company

Savannah River Site

Aiken, SC 29808

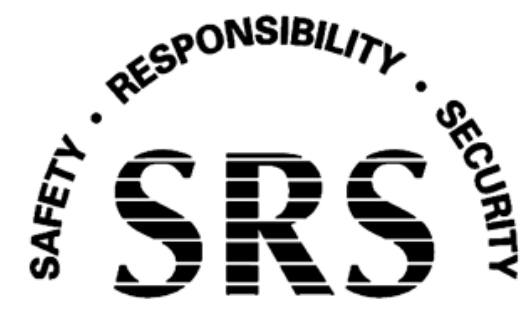


Crucible-Scale Active Vitrification Testing Envelope C, Tank 241-AN-102

DOCUMENT:

$$
\text { TITLE: }
$$

iii

WSRC-TR-2000-00371 SRT-RPP-2000-00022

Rev. 0

Formerly BNF-003-98-0271

WSRC-TR-2000-00371 (SRT-RPP-2000-00022)

Crucible-Scale Active Vitrification Testing Envelope C,

Tank 241-AN-102 (U)

APPROVALS

C. C Counted $5 / 22 / 01$

de arno ferrara

Date: $6 / 12 / 01$

D. M. Ferrara, Co-author (Immobilization Technology Section /SRTC)

D

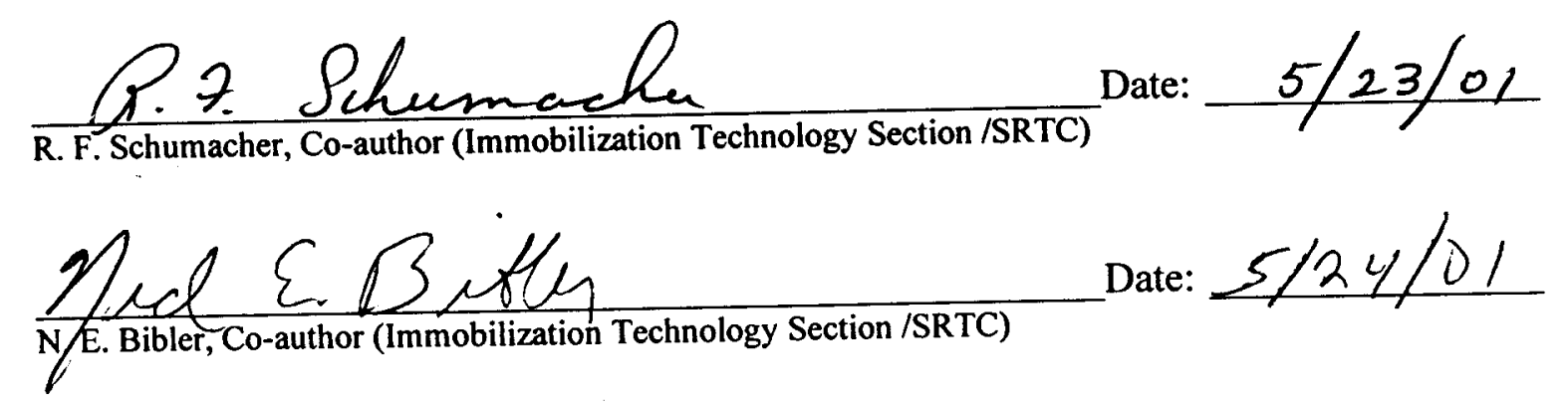

Paid A. Cowley

Date: $6 / 18 / 01$

$\frac{\text { T.B. Galloway per Teleconfereme }}{\text { Technical Reviewer, T. B. collowitay }}$ Date: $5-24-01$ 


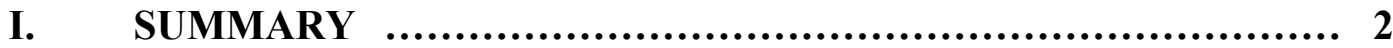

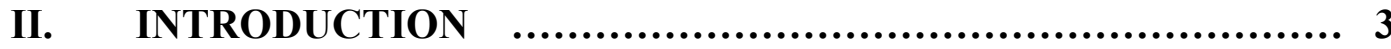

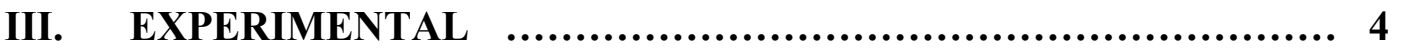

A. Feed Stream Evaporation and Waste Glass Formulation $\quad \ldots . . .4$

1) Decontaminated Liquid Feed Characterization $\ldots . \ldots \ldots \ldots . .4$

2) Waste Glass Formulation $\quad$..................................... 6

B. Vitrification $\quad$......................................................6 6

1) Waste Form Evaporation and Calcining $\ldots . \ldots \ldots \ldots \ldots \ldots . . . . .7$

2) Waste Form Vitrification $\quad$................................... 9

3) Glass Waste Form Cooling and Removal .................... 9

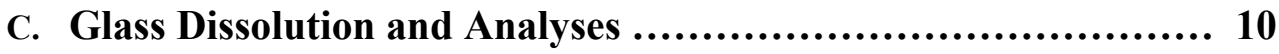

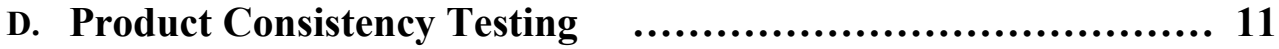

IV. RESULTS AND DISCUSSION $\quad \ldots \ldots \ldots \ldots \ldots \ldots \ldots \ldots \ldots \ldots \ldots \ldots \ldots \ldots$

A. Feed Stream Characterization and Waste Glass Formulation ... 11

1) Decontaminated Liquid Feed Characterization ................ 11

2) Waste Glass Formulation $\quad$..................................... 16

3) Glass Formers Blend Preparation and Analysis $\ldots . \ldots \ldots \ldots . .16$

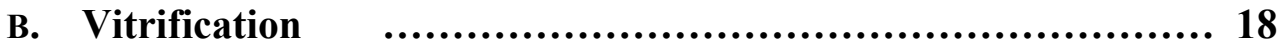

1) Mixing of Glass Formers and Waste Stream $\quad \ldots . . .18$

2) Crucible-Scale Vitrification ........................... 18

C. Glass Characterization $\quad$................................... 23

D. Product Consistency Test Glass Durability $\quad$............. 32

V. CONCLUSIONS

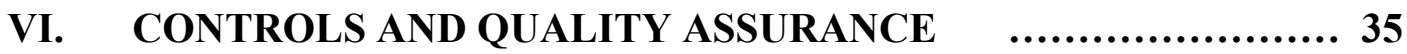

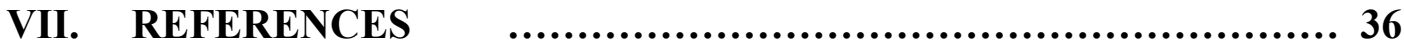

APPENDIX A AN-102 Active Glass Recipe from VSL APPENDIX B AN-102 Active Glass XRD and SEM/EDAX APPENDIX C Product Consistency Test Data APPENDIX D Data Sheets for Glass Former Minerals 


\section{SUMMARY}

As part of the Hanford River Protection Project-Waste Treatment Plant (RPP-WTP), the Savannah River Technology Center (SRTC) has produced and characterized an Immobilized Low Activity Waste (ILAW) glass from a pretreated, decontaminated Hanford Tank 241-AN-102 sample. The glass was made from a radioactive supernate that was pretreated by SRTC personnel using Sr-TRU precipitation to remove strontium and transuranic radionuclides and ion exchange to remove Cs-137 and Tc-99.

The AN-102 ILAW glass was produced from the decontaminated supernate feed referred to as 'Large C' sample. The $\sim 16 \mathrm{~L}$ decontaminated Large $\mathrm{C}$ supernate $(4.8+/-0.1)$ Molar sodium was analyzed and the characterization results were used to provide a glass formulation recipe targeted at nominally $11.8 \mathrm{wt} \% \mathrm{Na}_{2} \mathrm{O}$ in glass. An $86-\mathrm{mL}$ sub-sample of the characterized large $\mathrm{C}$ supernate was used to prepare an immobilized low-activity waste glass (ILAW) sample. The glass was vitrified from mixing this sub-sample and a blend of ten glass-forming minerals in a platinum/gold crucible and heating to $1150{ }^{\circ} \mathrm{C}$. The glass melts were then cooled following a prescribed cooling curve. All glasses were dissolved using versions of ASTM standard glass dissolution methods involving either sodium peroxide $\left(\mathrm{Na}_{2} \mathrm{O}_{2}\right)$ fusion with acid uptake, or heated digestion with a mixture of hydrofluoric (HF) and nitric $\left(\mathrm{HNO}_{3}\right)$ acids with boric acid uptake. Glasses were also dissolved by a $\mathrm{CsOH}$ fusion method for comparison. Measured composition of the resulting AN-102 glass waste form was close to the target composition. Compositions of standard Low Activity Reference Material LRM glass were also close to target compositions. Measured radionuclide levels in the glass indicate that the immobilized low activity wasteform is within the limits of the RP-WTP DOE/ORP contract specifications and the glass does not contain transuranic (TRU) radionuclides above the TRU wasteform limits.

No crystalline material was observed from X-ray Diffraction (XRD) and Scanning Electron Microscopy (SEM) analyses of the crushed glass. The ASTM standard Product Consistency Test (PCT) performed at $90^{\circ} \mathrm{C}$ on the $\mathrm{AN}-102$ radioactive glass and the Low Activity Reference standard LRM glass showed similar measured releases for the B, Si, $\mathrm{Na}$ components. The PCT results indicate that normalized released for $\mathrm{B}, \mathrm{Si}$, and $\mathrm{Na}$ are well below the specification limit of $2 \mathrm{~g}$ glass $/ \mathrm{m}^{2}$. 


\section{INTRODUCTION}

The Department of Energy, Office of River Protection is utilizing subcontractors to design, construct, and operate facilities to immobilize radioactive waste stored in underground tanks at the Hanford site near Richland, Washington [1,2]. The program is called the River Protection Project-Waste Treatment Plant (RPP-WTP). The current phase of this project is referred to as Part B-1 and includes activities for verification of technology and design of waste treatment facilities through August 24, 2000. Present studies are a continuation of previous collaborative efforts of BNFL, Inc. and the Savannah River Technology Center (SRTC) [3]. As part of the present Part B-1 SRTC demonstration, the Immobilization Technology Section (ITS) of SRTC has demonstrated, using a crucible-scale furnace, the vitrification portion of the process to producing an ILAW glass waste form from Hanford Tank 241-AN-102. This small active vitrification task evaporates and vitrifies samples from radioactive waste treatment demonstrations being performed by SRTC as part of a Work for Others (WFO) agreement $[1,4]$.

The objectives of this work were to characterize and performance test the vitrified product and to provide RPP-WTP personnel with the results from these studies. ${ }^{(1)}$ This is the final report for the small scale active vitrification testing on the AN-102 sample. RPP-WTP personnel have outlined the information that they are expecting from this study in a previous Task Specification document [4]. The scope of this report includes results from chemical and radionuclide analyses of 1) the Large $\mathrm{C}$ decontaminated supernate, 2) the dissolved glass, 3) crystalline-phase determinations in the glass by $\mathrm{X}$-ray diffraction (XRD) and scanning electron microscopy (SEM) and 4) durability Product Consistency Tests on the glass. Other tests performed on the glass include the Toxicity Characteristic Leaching Procedure (TCLP), density, and various organics, halides, anions and sulfur analyses. These latter TCLP, density and organics, halides, anions and sulfur analyses objectives and test results are described in a separate related 'Regulatory Analysis Report' prepared by ITS personnel at SRTC [5].

${ }^{(1)}$ Earlier work in this Part B1 program investigated sulfate removal from a portion of the AN-102 decontaminated supernate. The resulting sulfate-pretreated AN-102 supernate product was concentrated by evaporation and analyzed. Results of the analytical characterization were transmitted to VSL for glass formulation. However, it was decided by RPP-WTP personnel that sulfate removal by pretreatment was not to be pursued. Thus vitrification of the resulting glass former recipe developed by Vitreous State Laboratory for the sulfate-treated Env. C decontaminated supernate was not completed. A complete summary report on the sulfate pretreatment testing program, as well as the evaporation, characterization and glass formulation of the sulfate-treated Env. C, AN-102 sample is in preparation ("Sulfate Removal Studies for RPP Part B1", M. Hay et al., SRT-RPP-2000-00049, January, 2001). 


\section{EXPERIMENTAL}

\section{Feed Stream Characterization and Waste Glass Formulation}

The goal of the Feed Stream Characterization and Waste Glass Formulation phase was to analyze the decontaminated Envelope $\mathrm{C}$ supernate and mix the waste form and glassforming chemicals in a 600-mL platinum/gold crucible. The AN-102 LAW liquid was decontaminated of strontium-90 and transuranics by Sr-TRU precipitation pretreatment [6] and decontaminated of Cs and Tc by ion exchange pretreatment [7]. The pretreated AN-102 LAW supernate feed was mixed with glass-forming chemicals to complete the feed stream preparation phase. Except for preparation of supplies and glass-forming chemicals, the feed preparation was performed in radiochemical hoods within a radiological buffer area (RBA).

\section{$\underline{\text { Decontaminated Liquid Feed Characterization }}$}

The Large C decontaminated supernate was transferred from SRTC shielded cells facility to a Radiological Buffer Area (RBA) laboratory after completion of pretreatment tasks. The supernate was transferred in 20 separate 1-Liter polybottles. Approximately 16 Liters of sample were collected. All of the supernate was composited in two similar 10-Liter polybottles within a radiological hood in the RBA. Characterization of the two replicate 10-Liter containers was pursued by SRTC personnel. Table 1 shown below summarizes the analyses performed on the Large $C$ decontaminated supernate as well as other analyses performed in this vitrification task. 
Rev. 0

Table 1. Required Analytical Support for AN-102*

\begin{tabular}{|c||c|c|c|c|}
\hline Technique & $\begin{array}{c}\text { Composited, } \\
\text { Preteated } \\
\text { AN-102** }\end{array}$ & $\begin{array}{c}\text { Sample } \\
\text { Preparation } \\
\text { (Glass } \\
\text { Formers) }\end{array}$ & $\begin{array}{c}\text { PCT Leach } \\
\text { Tests }\end{array}$ & Glass Analyses \\
\hline \hline \multicolumn{1}{|c|}{ Na2 $_{2}$ Fusion } & & & & \\
\hline CsOH Fusion & & $\mathrm{X}$ & & $\mathrm{X}$ \\
\hline HNO3 Dissolve & & $\mathrm{X}$ & & $\mathrm{X}$ \\
\hline ICP-ES & $\mathrm{X}$ & $\mathrm{X}$ & $\mathrm{X}$ & $\mathrm{X}$ \\
\hline AA(Na/K) & $\mathrm{X}$ (K only) & & & $\mathrm{X}$ \\
\hline ICP-MS & $\mathrm{X}$ & & & $\mathrm{X}$ \\
\hline IC & $\mathrm{X}$ & & & $\mathrm{X}$ \\
\hline $\begin{array}{c}\text { Chemchek } \\
\text { (Total Uranium by }\end{array}$ & $\mathrm{X}$ & & & \\
\hline $\begin{array}{c}\text { Fluorescence } \\
\text { Spectroscopy) }\end{array}$ & & & & $\mathrm{X}$ \\
\hline Gamma-PHA & $\mathrm{X}$ & & & $\mathrm{X}$ \\
\hline Total Alpha-PHA & $\mathrm{X}$ & & & $\mathrm{X}$ \\
\hline Total Beta-Scint. & $\mathrm{X}$ & & & $\mathrm{X}$ \\
\hline Liquid Scint. & & & & \\
\hline Sr-90 & $\mathrm{X}$ & & & $\mathrm{X}$ \\
\hline Tc-99 & & & & \\
\hline TIC/TOC & $\mathrm{X}$ & & & \\
\hline Density,Wt\% Sol. & $\mathrm{X}$ & & & \\
\hline XRD & & & & \\
\hline SEM/EDAX & & & & \\
\hline Ion Sel. Electrode & $\mathrm{X}$ & & & \\
\hline Free OH & $\mathrm{X}$ & & & \\
\hline
\end{tabular}

* These analyses are to be performed at SRTC. Separate regulatory analyses are described in detail in Reference 5.

** Only Large C, AN-102 composited, pretreated supernate was characterized for this study. See text. 


\section{Waste Glass Formulation}

This step prepares the appropriate amount of melter feed for the crucible vitrifications. The appropriate amounts of decontaminated AN-102 liquid waste and a nonradioactive glass-forming chemical stream were mixed directly in the crucibles. All glass-forming chemicals were comprised of various mineral compositions specified by Vitreous State Laboratory (VSL). Previous studies in Part A work used reagent grade chemicals as the glass-forming chemicals [3]. Ongoing developmental work performed with waste simulants at VSL at Catholic University and at SRTC [8] supports this task. The results from the VSL development work form the basis for the formulations used in this step. The types and forms of industrial grade glass formers used in this study are the same as those used in the VSL development to facilitate comparison of the glasses made from simulated and actual waste.

Decontaminated AN-102 supernate was analyzed by sampling each of the two similar 10Liter carboys containing the Large $\mathrm{C}$ sample in duplicate according to the analyses shown in Table 1. Average results from these four replicate analyses were transmitted to VSL, who then communicated to SRTC the appropriate amounts of the waste streams, composition of the glass-forming chemicals, and appropriate amounts of the glassforming chemicals. RPP-WTP personnel reviewed the recommendations and approved them before SRTC blended the glass formers.

As an additional quality assurance step, SRTC analyzed a representative portion of the final glass formers according to Table 1, and confirmed that analyzed components for $\mathrm{Al}$, $\mathrm{B}, \mathrm{Cr}, \mathrm{Fe}, \mathrm{Li}, \mathrm{Mg}, \mathrm{Si}, \mathrm{Ti}, \mathrm{Zn}, \mathrm{Zr}$ agreed with as-batched values before actual mixing of the glass forming chemicals and decontaminated feed stream. The final mixtures of glass-forming chemicals and pretreated AN-102 feed were prepared in $600-\mathrm{mL}$ platinum/gold crucibles for the batch tests. Balances used to measure the glass-forming chemicals, to determine the mass of each stream, etc. were standard, single-pan, toploading analytical balances. All balances are calibrated by the SRTC standards lab using NIST-traceable standards. Calibration checks were performed with standard masses that bracket the mass of the material to be weighed prior to all weighings.

\section{Vitrification}

The goal of the Vitrification phase was to immobilize the AN-102 waste stream in glass matrix that could then be characterized and performance tested. The target melt temperature for all active crucible scale vitrifications was $1150^{\circ} \mathrm{C}$. The $\mathrm{AN}-102$ waste stream is a Resource Conservation and Recovery Act (RCRA) listed waste. Therefore, an offgas system was used for the vitrification testing to maintain certain listed waste component effluent levels below the allowable limits within SRTC lab facilities [4]. Evaporation and calcining occurred in the furnace at temperatures from $100^{\circ} \mathrm{C}$ to $900^{\circ} \mathrm{C}$. Heat-up rates during these steps were nominally $<100^{\circ} \mathrm{C} /$ hour. The furnace temperature was then increased from $900^{\circ} \mathrm{C}$ to $1150^{\circ} \mathrm{C}$ at a nominal heat-up rate of $100^{\circ} \mathrm{C} /$ hour. The vitrification temperature of $1150^{\circ} \mathrm{C}$ was held for 4 hours. After vitrification, the glass 
waste form was cooled according to a prescribed cooling schedule provided by VSL/RPP-WTP.

\section{Waste Form Evaporation and Calcining}

After mixing the glass-forming chemicals with the pretreated waste in the vitrification crucible and transferring the resulting slurry to the vitrification furnace, water from the slurry was slowly removed by evaporation. This process is described in more detail below. A detailed diagram of the furnace as configured for these studies is presented in Figure 1. The furnace used for these studies is a DelTech Model DT-29-TL-610 Top Loading Laboratory Furnace capable of $1200^{\circ} \mathrm{C}$ with a programmable setpoint temperature control. The furnace was initially 'baked out' and calibration-tested before use according to recommended procedures by the vendor. Thermocouples and digital readouts used for calibration of the furnace were calibrated by the SRTC standards lab with NIST-traceable standards.

An offgas collection glassware apparatus was attached to the quartz glass system within the furnace. This offgas system contained and trapped all gaseous hazardous species evolved during the slurry evaporation, calcine and vitrification steps. The offgas system contained a primary water-cooled condenser, a dry ice bath and two activated carbon beds in series. A collection pot was connected to the water condenser for final collection of all condensed phase liquid collected during the evaporation and calcine steps. As shown in Figure 1, ambient air flowed into a quartz tube through an inlet carbon filter. The quartz vessel inside of the furnace contained an alumina insert that held the vitrification crucible. Incoming air will swept through the quartz tube carrying offgas from inside the sealed quartz vessel system to the offgas system (condenser, cold trap and carbon filters). The central offgas tube exits the furnace through a 1" diameter opening cut out of the top of the furnace. All loading of equipment and samples into the furnace was performed through a top-located circular furnace door of 6" diameter (not shown in Figure 1).

The final carbon filter in the offgas system was connected to vacuum. A vacuum of nominally 2-3 inches of water was maintained on the crucible throughout the entire vitrification process. The vacuum was monitored periodically by connecting a water manometer to the air inlet. Vacuum was supplied by SRTC facility-supplied vacuum through a connection within the radiochemical hood.

Temperatures of the furnace were slowly increased to remove the water from the slurry contained in the crucible and collect it in the trap below the condenser. The nominal heatup rate was $10^{\circ} \mathrm{C} /$ hour. After the water was evolved from the waste form, the volatile species were driven off by slow temperature increases typically between $200{ }^{\circ} \mathrm{C}$ and $900{ }^{\circ} \mathrm{C}$. Initial planning required use of a $250-\mathrm{mL}$ crucible. However, due to increased amounts of glass product needed for all planned analyses, a $600-\mathrm{mL}$ platinum/gold crucible was used. 
(Offgas exits to: (1) water condenser, (2) dry ice bath, (3) carbon filters in series)

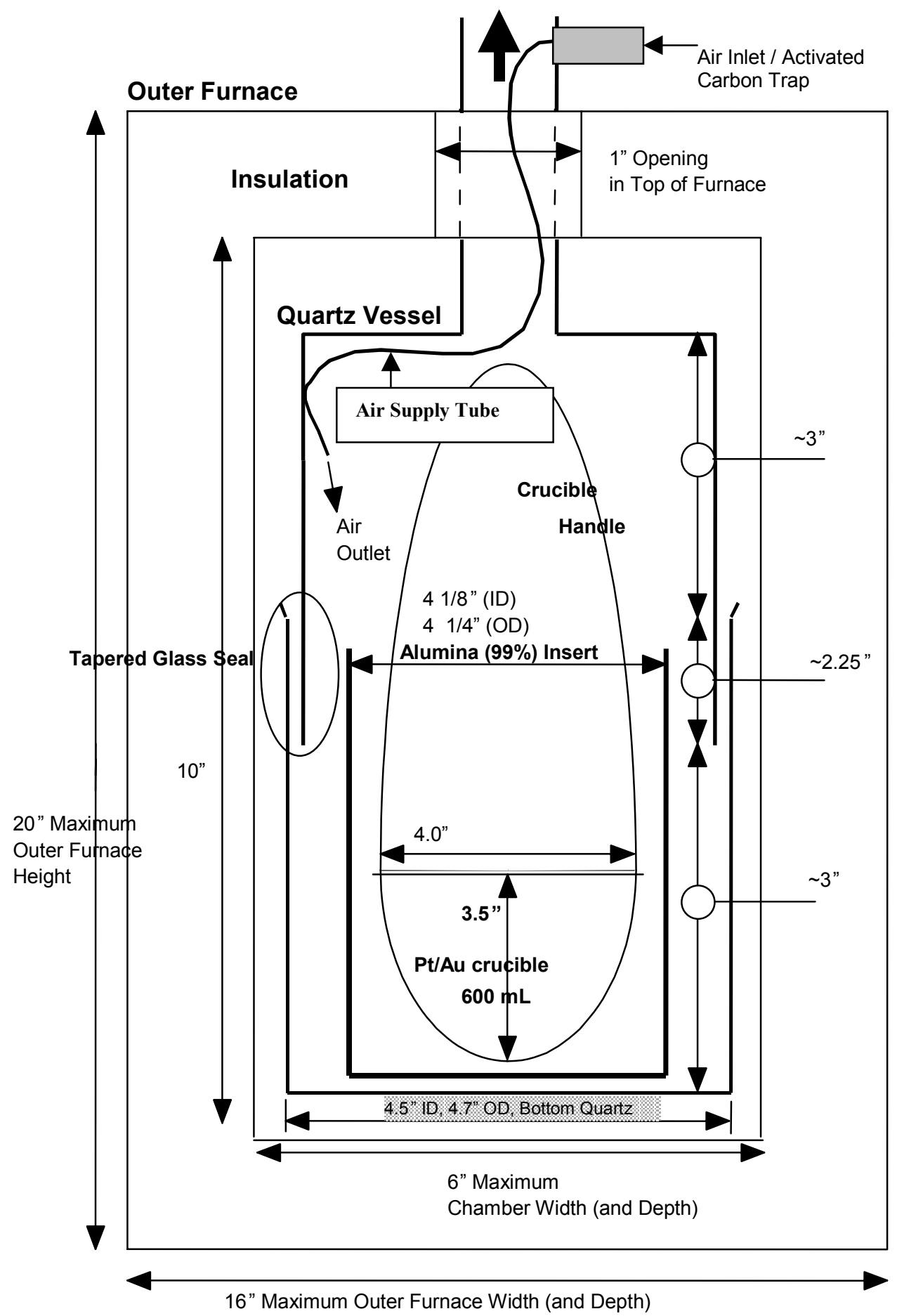

Figure 1. Small Active Crucible-Scale Furnace 


\section{$\underline{\text { Waste Form Vitrification }}$}

The waste form was vitrified in the same furnace used to calcine the waste form.

The temperature was slowly increased from $900^{\circ} \mathrm{C}$, to the melt temperature of $1150^{\circ} \mathrm{C}$, where it was held at this temperature for $\sim 4$ hours.

\section{Glass Waste Form Cooling and Removal}

After the melting period, the molten glass was cooled inside of the furnace according to the cooling schedule provided by VSL/RPP-WTP [LAW Cooling Curve Source: E-mail sent to T. B. Calloway (SRTC) on 11/15/99 from S. Arm (formerly with BNFL,Inc., currently with CHG), CHG Reference \# is 009325]. The glass cooling profile was intended to simulate the temperature cooling profile of glass in containers planned for the RPP-WTP. The temperature range for the controlled cooling was $1100{ }^{\circ} \mathrm{C}$ to $400^{\circ} \mathrm{C}$. This cooling profile is shown in Figure 2. After the furnace program reached the lower temperature of the cooling schedule, heating of the furnace was discontinued and the system was allowed to cool to ambient temperature. The glass and offgas system were handled after the furnace vitrification system was at ambient temperature. Liquids from the condensate traps will be collected and their amounts measured by volume. No analyses were planned for any of the small active vitrification condensates resulting from crucible-scale furnace vitrification activities.

Figure 2. Cooling Curve for AN-102 Vitrification

\section{ILAW Centerline Cooling profile (2/5 up from base)}

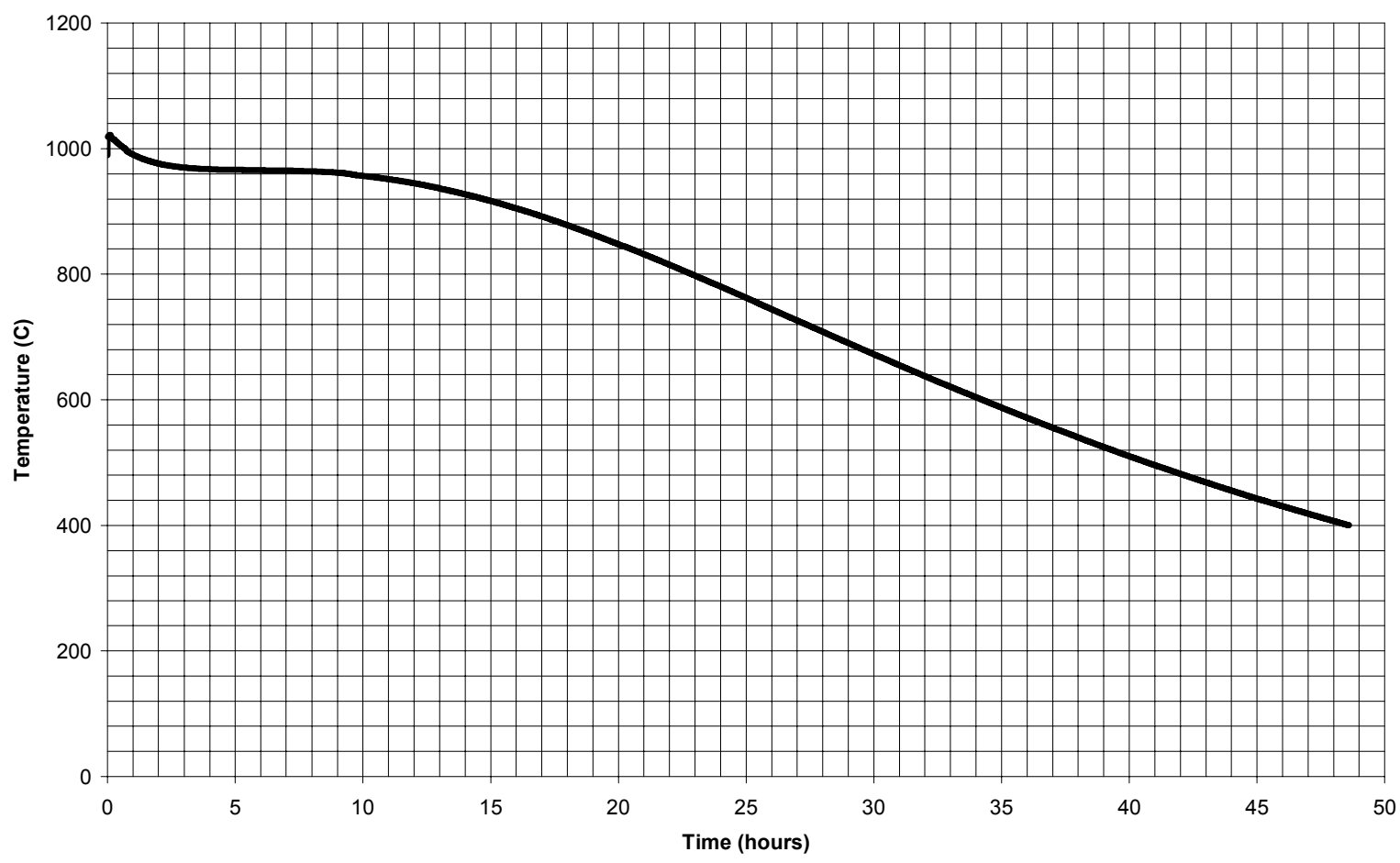




\section{Glass Dissolution and Analyses}

Formerly BNF-003-98-0271

Product glass for the active AN-102 sample was initially size-reduced by manually grinding the glass pieces using an agate mortar and pestle. The glass was then further pulverized to a (-) 200 mesh size using a Mixer Mill with agate cups and agate grinding ball. Samples of the standard Low Activity Reference Material LRM glass $[9,10]$ were also ground in the Mixer Mill. Resulting glass powders were verified to be (-) 200 mesh by passing through an ASTM-certified brass sieve. These powdered glass samples were then dissolved using versions of ASTM glass dissolution procedures involving $\mathrm{Na}_{2} \mathrm{O}_{2} / \mathrm{NaOH}$ fusion with acid uptake (ASTM C 1317-95), and acid dissolution (ASTM $\mathrm{C}$ 1412-99). A third method for glass dissolution involving $\mathrm{CsOH}$ fusion was also examined in this study for both the active AN-102 glass and the LRM standard glass. This $\mathrm{CsOH}$ method is under investigation as a singular, comprehensive dissolution method for glass dissolution that could provide measured values for all analytes in the glass with a single dissolution method.

The peroxide fusion method used nominally 0.5 gram powdered glass samples added to 3 grams of $\mathrm{Na}_{2} \mathrm{O}_{2}$ and 2 grams of $\mathrm{NaOH}$ in Ni-crucibles. The resulting mixture was heated in a Thermolyne furnace at $700{ }^{\circ} \mathrm{C}$ for 15 minutes. The resulting mixture was then cooled and transferred to a $100-\mathrm{mL}$ volumetric plastic flask. A volume of $25 \mathrm{~mL}$ of concentrated 15.7 Molar nitric acid was used to rinse the crucible and also added to the flask. The sample was then diluted to the 100-ml mark of the volumetric flask.

The acid dissolution method used nominally 0.5 gram powdered glass samples added to a wide mouth plastic bottle. Then $10 \mathrm{~mL}$ of $50 \%(\sim 29$ Molar $) \mathrm{HF}$ and $10 \mathrm{~mL}$ of concentrated 15.7 Molar $\mathrm{HNO}_{3}$ were added. The bottle was capped and the mixture was heated in an oven at $105^{\circ} \mathrm{C}$ for 2 hours. The mixture was then cooled, $70 \mathrm{~mL}$ of 0.6 Molar boric acid was added and the Teflon pressure re-sealed and heated for an additional hour. After cooling, the solution was diluted to $100 \mathrm{ml}$ in a volumetric flask with deionized water.

The $\mathrm{CsOH}$ fusion method combines nominally $0.25 \mathrm{~g}$ of powdered glass with the $\mathrm{CsOH}$ pellet remaining after the pre-heating step (about 2.6-2.7 g) in a nickel crucible and heats at $500^{\circ} \mathrm{C}$ for 2 minutes. The powder form of $\mathrm{CsOH} \cdot \mathrm{H}_{2} \mathrm{O}$ will splatter when placed in a muffle furnace at $500^{\circ} \mathrm{C}$. In order to prevent the possible loss of sample from splattering, $3.0 \mathrm{~g}$ of $\mathrm{CsOH} \cdot \mathrm{H}_{2} \mathrm{O}$ was first heated to $500^{\circ} \mathrm{C}$ in a nickel crucible for 2 minutes to remove excess moisture. The pellet that forms in the bottom of the crucible is much less deliquescent than the powder form of $\mathrm{CsOH} \cdot \mathrm{H}_{2} \mathrm{O}$, but still must be protected from air to prevent re-absorption of moisture. After cooling the sample (preheated $\mathrm{CsOH}$ pellet plus glass) until warm, the fusion residue was dissolved first with de-ionized water containing 2-3 drops of $30 \% \mathrm{H}_{2} \mathrm{O}_{2}$ and then $25 \mathrm{ml}$ of 15.7 molar nitric acid. The acid solution was then diluted to $250 \mathrm{ml}$ with de-ionized water.

All dissolved glasses were analyzed using the methods shown in Table 1 above. 


\section{Product Consistency Test}

The Product Consistency Test (PCT) was performed at $90^{\circ} \mathrm{C}$ on the LAW glasses. The SRTC Task Plan for this work (SRTC document BNF-003-98-0138, Rev. 0, Jan. 25, 2000) specifies that both $90{ }^{\circ} \mathrm{C}$ and $40{ }^{\circ} \mathrm{C}$ Product Consistency Tests were to be performed on the LAW glasses. However, RPP-WTP project personnel subsequently requested that the $40{ }^{\circ} \mathrm{C}$ PCT not be performed. This change is reflected in the referenced Mod. No. M014 Section C: Statement of Work from November 2000 [1]. The durability was measured using the ASTM C-1285 standard nuclear waste glass durability test commonly referred to as the Product Consistency Test (PCT) [11]. This is a crushed glass leach test at $90{ }^{\circ} \mathrm{C}$ for 7 days using deionized water as leachate. The ground glass samples used for the PCT were prepared by grinding in a rotary blade grinder. This grinder contains a tungsten carbide blade and a stainless steel chamber. Triplicate tests were performed in sealed stainless steel vessels. The active AN-102 and Low Activity Reference standard LRM glasses were tested at $90^{\circ} \mathrm{C}+/-2^{\circ} \mathrm{C}$. Final leachate $\mathrm{pH}$ 's were measured and final elemental concentrations of the filtered, acidified leachates were measured by ICP-ES. Purified ASTM Type I water obtained from a MilliQ water purification system was used as leachate in all tests. Ultrapure nitric acid was used to acidify the leachates prior to analysis.

\section{RESULTS AND DISCUSSION}

\section{Feed Stream Characterization and Waste Glass Formulation}

\section{Decontaminated Feed Characterization}

Decontaminated AN-102 supernate was analyzed by sampling each of the two similar 10-Liter carboys containing the Large $\mathrm{C}$ sample in duplicate according to the analyses shown in Table 1. No dilutions were performed on the decontaminated Large $\mathrm{C}$ composite supernate prior to submission to SRTC ADS for analysis. Table 2 below shows the data obtained from the duplicate analysis from each composite. Values reported in Table 2 with a less than sign, ' $<$, , represent the reported instrument detection limit value. Average values, standard deviation and \% relative standard deviation determined from the four replicate values (1A, 1B, 2A and 2B) are shown for analytes that were detected above the instrument detection limit. In cases where some of the replicate analyte values were below detection limit, an upper limit average value is given. Average results from these four replicate analyses were transmitted to VSL, who then communicated to SRTC the appropriate amounts of the waste streams, composition of the glass-forming chemicals, and appropriate amounts of the glass-forming chemicals.

Review of the data shown in Table 2 indicates good agreement between the two large composite bottles. Radiochemical analysis of Cs-137 and Sr-90 shows precision in the range of $7 \%$ to $15 \%$. Mass spectral analysis for mass-99 indicates Tc-99 precision in the two composites to be better than $1 \%$. Other comparisons between the two composites for 
the other analytical methods shown indicate good agreement between the two large composites, i.e., Na/Al from ICP-ES, TIC/TOC from wet chemical methods, $\mathrm{K}$ from AA and $\mathrm{NO}_{3} / \mathrm{NO}_{2}$ from IC-anions. Mass spectrometry values for Tc-99 in units of $\mathrm{mg} / \mathrm{L}$ were converted to specific activity values in units of $\mu \mathrm{Ci} / \mathrm{mL}$ via Equation 1 ,

\section{Equation 1:}

$$
\mathrm{a}=3.5778 \mathrm{E}+05 \times\left(\mathrm{g} /\left(\mathrm{t}_{\mathrm{Y}} \times \mathrm{M}\right)\right)
$$

Where:

$\mathrm{a}=$ activity in Curies $(\mathrm{Ci})$

$3.5778 \mathrm{E}+05=$ constant $(\mathrm{Ci} *$ years $/ \mathrm{g})$

$\mathrm{g}=$ mass in grams

$\mathrm{t}_{\mathrm{Y}}=1 / 2$ life of $\mathrm{Tc}-99$ in years $=2.13 \mathrm{E}+05$ years

$\mathrm{M}=$ mass number of Tc-99 $=99$

Using the average mass spectral value for Tc-99 from Table 2 as $2.78 \mathrm{mg} / \mathrm{L}$ and solving Equation 1 above, one calculates an average specific activity for Tc-99 in the composite to be $4.72 \mathrm{E}-02 \mu \mathrm{Ci} / \mathrm{mL}$, via:

$\mathrm{a}(\mathrm{Ci} / \mathrm{L})=3.5778 \mathrm{E}+05 \times(0.00278 \mathrm{~g} / \mathrm{L} /(2.13 \mathrm{E}+05 \times 99))$

$\mathrm{a}(\mathrm{Ci} / \mathrm{L})=4.72 \mathrm{E}-05 \mathrm{Ci} / \mathrm{L}$, or $4.72 \mathrm{E}-02 \mu \mathrm{Ci} / \mathrm{mL}$ 
Table 2. AN-102 Large C Concentrate Composite Analyses

Decontaminated Large C Composites

Composite

$1 \mathrm{~A}$

\section{Radiochemical}

$$
(\mathrm{uCi} / \mathrm{mL})
$$

Co-60

Cs-137

Eu-154

Eu-155

Am-241

Total Alpha

Total Beta

Sr-90

3.81E-02

4.54E-02

2.93E-02

2.27E-02

1.61E-02

8.95E-02

4.38

1.41

ICP-Mass Spectroscopy

\begin{tabular}{|c|c|c|c|c|}
\hline & & $(\mathrm{mg} / \mathrm{L})$ & & $(\mathrm{mg} / \mathrm{L})$ \\
\hline mass 99 & & $2.77 \mathrm{E}+00$ & & $2.78 \mathrm{E}+00$ \\
\hline $\begin{array}{c}\text { ** Mass } 99(\mathrm{Tc}) \\
\mu \mathrm{Ci} / \mathrm{mL}\end{array}$ & & 4.69E-02 & & 4.71E-02 \\
\hline mass 230 & $<$ & 3.30E-03 & $<$ & 3.30E-03 \\
\hline mass 231 & $<$ & 3.30E-03 & $<$ & 3.30E-03 \\
\hline mass 232 (Th) & & $1.51 \mathrm{E}+00$ & & $1.46 \mathrm{E}+00$ \\
\hline mass 233 & $<$ & 3.30E-03 & $<$ & 3.30E-03 \\
\hline mass $234(\mathrm{U})$ & $<$ & 3.30E-03 & $<$ & 3.30E-03 \\
\hline mass $235(\mathrm{U})$ & & 8.88E-03 & & 8.68E-03 \\
\hline mass $236(\mathrm{U})$ & $<$ & 3.30E-03 & $<$ & $3.30 \mathrm{E}-03$ \\
\hline mass $237(\mathrm{~Np})$ & & 8.78E-02 & & 8.93E-02 \\
\hline mass $238(\mathrm{Pu} \& \mathrm{U})$ & & 8.64E-01 & & 8.77E-01 \\
\hline mass $239(\mathrm{Pu})$ & & $1.50 \mathrm{E}-02$ & & $1.54 \mathrm{E}-02$ \\
\hline mass $240(\mathrm{Pu})$ & $<$ & 3.30E-03 & $<$ & 3.30E-03 \\
\hline mass $241(\mathrm{Am} \& \mathrm{Pu}$ & & 7.46E-03 & & 7.83E-03 \\
\hline mass $242(\mathrm{Pu})$ & $<$ & $3.30 \mathrm{E}-03$ & $<$ & $3.30 \mathrm{E}-03$ \\
\hline mass $243(\mathrm{Am})$ & $<$ & 3.30E-03 & $<$ & 3.30E-03 \\
\hline mass $244(\mathrm{Cm})$ & $<$ & $3.30 \mathrm{E}-03$ & $<$ & 3.30E-03 \\
\hline mass $245(\mathrm{Cm})$ & $<$ & $3.30 \mathrm{E}-03$ & $<$ & $3.30 \mathrm{E}-03$ \\
\hline mass 246 & $<$ & 3.30E-03 & $<$ & $3.30 \mathrm{E}-03$ \\
\hline
\end{tabular}

\section{Composite \\ 2A}

$$
\text { (uCi/mL) }
$$

4.10E-02

4.66E-02

3.63E-02

2.38E-02

$<$ 1.38E-02

6.09E-02

4.46

1.21

$(\mathrm{uCi} / \mathrm{mL})$
$4.15 \mathrm{E}-02$
$6.17 \mathrm{E}-02$
$3.71 \mathrm{E}-02$
$2.45 \mathrm{E}-02$
$1.42 \mathrm{E}-02$
$7.59 \mathrm{E}-02$
4.11
1.41

(mg/L)

2.78E+00

4.71E-02

$<\quad 3.30 \mathrm{E}-03$

$<3.30 \mathrm{E}-03$

$1.46 \mathrm{E}+00$

$<$ 3.30E-03

< 3.30E-03

1.07E-02

< 3.30E-03

8.82E-02

9.39E-01

1.35E-02

$<\quad 3.30 \mathrm{E}-03$

7.09E-03

< 3.30E-03

$<\quad 3.30 \mathrm{E}-03$

< 3.30E-03

< 3.30E-03

$<$ 3.30E-03

\section{Composite \\ 2B}

(uCi/mL) 3.92E-02

5.75E-02

3.41E-02

2.18E-02

2.10E-02

3.45E-02

4.27

1.37

(mg/L)

\section{$2.81 \mathrm{E}+00$}

4.77E-02

< 3.30E-03

$<\quad 3.30 \mathrm{E}-03$

$1.45 \mathrm{E}+00$

$<\quad 3.30 \mathrm{E}-03$

< 3.30E-03

1.03E-02

$<$

3.30E-03

8.79E-02

9.35E-01

1.41E-02

3.30E-03

7.69E-03

$<\quad 3.30 \mathrm{E}-03$

$<3.30 \mathrm{E}-03$

< 3.30E-03

< 3.30E-03

$<$ 3.30E-03
Average*

**

St. Dev. * \%Rel.

St. Dev.*

$(\mathrm{uCi} / \mathrm{mL})$
$3.99 \mathrm{E}-02$
$5.28 \mathrm{E}-02$
$3.42 \mathrm{E}-02$
$2.32 \mathrm{E}-02$
$<\quad 1.63 \mathrm{E}-02$
$6.52 \mathrm{E}-02$
4.31
1.35

(uCi/mL)

$1.56 \mathrm{E}-03 \quad 3.9$

8.06E-03 15.3

3.49E-03 10.2

1.18E-03 5.1

NA NA

2.36E-02 36.1

1.52E-01 3.5

9.52E-02 7.1

\begin{aligned} & $(\mathrm{mg} / \mathrm{L}) \\ & 2.78 \mathrm{E}+00 \\ & 4.72 \mathrm{E}-02 \\ & \\ < & 3.30 \mathrm{E}-03 \\ < & 3.30 \mathrm{E}-03 \\ & 1.47 \mathrm{E}+00 \\ < & 3.30 \mathrm{E}-03 \\ < & 3.30 \mathrm{E}-03 \\ & 9.63 \mathrm{E}-03 \\ < & 3.30 \mathrm{E}-03 \\ & 8.83 \mathrm{E}-02 \\ & 9.03 \mathrm{E}-01 \\ < & 1.45 \mathrm{E}-02 \\ & 3.30 \mathrm{E}-03 \\ < & 7.52 \mathrm{E}-03 \\ < & 3.30 \mathrm{E}-03 \\ < & 3.30 \mathrm{E}-03 \\ < & 3.30 \mathrm{E}-03 \\ < & 3.30 \mathrm{E}-03 \\$\hline & $3.30 \mathrm{E}-03\end{aligned}$

$(\mathrm{mg} / \mathrm{L})$

1.98E-02 0.7

3.36E-04 0.7

$\begin{array}{cc}\text { NA } & \text { NA } \\ \text { NA } & \text { NA } \\ 2.57 E-02 & 1.8 \\ \text { NA } & \text { NA } \\ \text { NA } & \text { NA } \\ 9.96 E-04 & 10.3 \\ \text { NA } & \text { NA } \\ 6.76 E-04 & 0.8 \\ 3.89 E-02 & 4.3 \\ 8.64 E-04 & 6.0 \\ \text { NA } & \text { NA } \\ 3.25 E-04 & 4.3 \\ \text { NA } & \text { NA } \\ \text { NA } & \text { NA } \\ \text { NA } & \text { NA } \\ \text { NA } & \text { NA } \\ \text { NA } & \text { NA }\end{array}$

ICP-Emission

\begin{tabular}{|c|c|c|c|c|c|c|c|c|c|c|c|}
\hline כ ק & & $(\mathrm{mg} / \mathrm{L})$ & $(\mathrm{mg} / \mathrm{L})$ & & $(\mathrm{mg} / \mathrm{L})$ & & $(\mathrm{mg} / \mathrm{L})$ & & (mg/L) & (mg/L) & $(\%)$ \\
\hline $\mathrm{Al}$ & & $5.39 E+03$ & $4.51 \mathrm{E}+03$ & & $5.70 \mathrm{E}+03$ & & $5.84 \mathrm{E}+03$ & & $5.36 \mathrm{E}+03$ & $6.01 \mathrm{E}+02$ & 11.2 \\
\hline B & & $1.37 \mathrm{E}+01$ & $1.14 \mathrm{E}+01$ & & $1.39 \mathrm{E}+01$ & & $1.44 \mathrm{E}+01$ & & $1.34 \mathrm{E}+01$ & $1.32 \mathrm{E}+00$ & 9.9 \\
\hline $\mathrm{Ba}$ & $<$ & $1.82 \mathrm{E}-01$ & 4.69E-01 & $<$ & 1.82E-01 & $<$ & $1.82 \mathrm{E}-01$ & $<$ & $2.54 \mathrm{E}-01$ & NA & NA \\
\hline $\mathrm{Ca}$ & & $1.12 \mathrm{E}+02$ & $9.40 \mathrm{E}+01$ & & $1.18 \mathrm{E}+02$ & & $1.20 E+02$ & & $1.11 \mathrm{E}+02$ & $1.19 \mathrm{E}+01$ & 10.8 \\
\hline
\end{tabular}

Spectroscopy 
Crucible-Scale Active Vitrification Testing

Envelope C, Tank 241-AN-102

14

Table 2, Continued ICP-ES

\begin{tabular}{|c|c|c|}
\hline & $\begin{array}{c}1 \mathrm{~A} \\
(\mathrm{mg} / \mathrm{L})\end{array}$ & $\begin{array}{c}1 \mathrm{~B} \\
(\mathrm{mg} / \mathrm{L})\end{array}$ \\
\hline $\mathrm{Cd}$ & $1.99 \mathrm{E}+01$ & $1.67 E+01$ \\
\hline Co & $1.57 \mathrm{E}+00$ & $1.95 E+00$ \\
\hline $\mathrm{Cr}$ & $7.07 \mathrm{E}+01$ & $5.93 E+01$ \\
\hline $\mathrm{Cu}$ & $3.58 \mathrm{E}+00$ & $3.39 E+00$ \\
\hline $\mathrm{Fe}$ & $2.14 \mathrm{E}+00$ & $2.15 E+00$ \\
\hline La & $1.25 \mathrm{E}+00$ & $2.16 \mathrm{E}+00$ \\
\hline $\mathrm{Li}$ & 1.83E-01 & 5.34E-01 \\
\hline Mg & $<9.10 \mathrm{E}-02$ & $9.70 \mathrm{E}-02$ \\
\hline $\mathrm{Mn}$ & 8.16E-01 & 7.83E-01 \\
\hline Mo & $2.25 \mathrm{E}+01$ & $1.81 \mathrm{E}+01$ \\
\hline $\mathrm{Na}$ & $1.10 \mathrm{E}+05$ & $1.07 \mathrm{E}+05$ \\
\hline $\mathrm{Ni}$ & $1.23 \mathrm{E}+02$ & $1.03 E+02$ \\
\hline$P$ & $7.05 E+02$ & $5.71 E+02$ \\
\hline $\mathrm{Pb}$ & $4.40 \mathrm{E}+01$ & $3.92 E+01$ \\
\hline $\mathrm{Si}$ & $4.35 \mathrm{E}+01$ & $1.21 E+01$ \\
\hline Sn & $1.19 \mathrm{E}+01$ & $9.82 E+00$ \\
\hline $\mathrm{Sr}$ & $1.27 \mathrm{E}+02$ & $1.02 E+02$ \\
\hline Tc & $2.83 E+00$ & $2.79 E+00$ \\
\hline $\mathrm{Ti}$ & 3.05E-01 & 7.63E-01 \\
\hline V & 6.07E-01 & $1.29 E+00$ \\
\hline $\mathrm{Zn}$ & $1.40 \mathrm{E}+00$ & $1.25 \mathrm{E}+00$ \\
\hline $\mathrm{Zr}$ & $<3.64 \mathrm{E}-01$ & $<\quad 3.64 \mathrm{E}-01$ \\
\hline
\end{tabular}

IC Anions

$\begin{array}{cc}\mathrm{Cl} & 1.60 \mathrm{E}+03 \\ \mathrm{~F} & 7.69 \mathrm{E}+02 \\ \text { Formate } & 4.58 \mathrm{E}+03 \\ \mathrm{NO} 2 & 3.65 \mathrm{E}+04 \\ \mathrm{NO} 3 & 8.56 \mathrm{E}+04 \\ \mathrm{SO} 4 & 5.59 \mathrm{E}+03 \\ \mathrm{PO} 4 & 2.68 \mathrm{E}+03 \\ \text { Oxalate } & 1.15 \mathrm{E}+03\end{array}$

\section{Composite \\ 2A \\ (mg/L)}

2.12E+01

$1.46 \mathrm{E}+00$

$7.46 \mathrm{E}+01$

$3.61 \mathrm{E}+00$

$1.70 \mathrm{E}+00$

$<1.00 \mathrm{E}+00$

$<$ 1.82E-01

$<$ 9.10E-02

7.91E-01

$2.21 \mathrm{E}+01$

$1.16 \mathrm{E}+05$

$1.33 \mathrm{E}+02$

$7.30 \mathrm{E}+02$

4.73E+01

$3.91 \mathrm{E}+01$

$1.10 \mathrm{E}+01$

1.37E+02

$2.41 \mathrm{E}+00$

$<$ 1.82E-01

$<$

2.73E- 01

$1.30 \mathrm{E}+00$

5.05E-01

$<$

Composite 2B

(mg/L)

2.19E+01

$1.24 \mathrm{E}+00$

7.64E+01

$3.76 \mathrm{E}+00$

1.73E+00

$1.00 \mathrm{E}+00$

1.82E-01

9.10E-02

8.00E-01

$2.32 \mathrm{E}+01$

1.13E+05

$1.36 \mathrm{E}+02$

$7.42 \mathrm{E}+02$

$4.71 \mathrm{E}+01$

$4.09 \mathrm{E}+01$

$1.12 \mathrm{E}+01$

$1.40 \mathrm{E}+02$

$2.05 \mathrm{E}+00$

1.82E-01

2.73E-01

$1.22 \mathrm{E}+00$

$3.64 \mathrm{E}-01$

1.56E+03

$7.77 \mathrm{E}+02$

$4.60 \mathrm{E}+03$

$3.62 \mathrm{E}+04$

$8.65 \mathrm{E}+04$

$5.48 \mathrm{E}+03$

$1.73 \mathrm{E}+03$

$9.98 \mathrm{E}+02$
WSRC-TR-2000-00371

SRT-RPP-2000-00022

Rev. 0

ormerly BNF-003-98-0271 
Rev. 0

Formerly BNF-003-98-0271

Table 2,

Continued

Ion Selective

Electrode

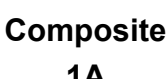

$1 \mathrm{~A}$

(mg/L)

179.6

119.4

$\mathrm{F}$

TIC/TOC

TIC

TOC
(mg/L)

5782

11432

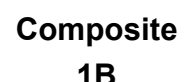

(mg/L)

188.5

105.85

(mg/L)

5618

11617

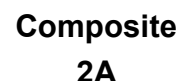

2A

(mg/L)

213.2

93.78

$(\mathrm{mg} / \mathrm{L})$
6294
11814

Composite

2B

(mg/L)

218.34

10

(mg/L)

5656

10732
Average*

St. Dev. * \%Rel.

1814

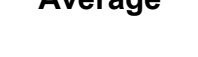

(mg/L)

2.00E+02

$<8.23 \mathrm{E}+01$

$\begin{array}{ccc}(\mathrm{mg} / \mathrm{L}) & (\mathrm{mg} / \mathrm{L}) & (\%) \\ 5.84 \mathrm{E}+03 & 3.12 \mathrm{E}+02 & 5.3 \\ 1.14 \mathrm{E}+04 & 4.71 \mathrm{E}+02 & 4.1\end{array}$

\section{Notes:}

* Average (Composite 1A, 1B, 2A, 2B), 1-sigma Standard Deviation (Composite $1 \mathrm{~A}, 1 \mathrm{~B}, 2 \mathrm{~A}, 2 \mathrm{~B})$ and \% Relative Standard Deviation (\%RSD calculated from [(St.Dev./Average $\left.\left.)^{*} 100\right]\right)$

$(\mathrm{NA})=$ Not Applicable due to one or more replicate analyte values determined below the instrument detection limit.

** Tc-99 specific activity $(\mu \mathrm{Ci} / \mathrm{mL})$ calculated from ICP-MS value. See text. 
$\underline{\text { Waste Glass Formulation }}$

Results of the AN-102 Large C composite analyses were transmitted to the VSL to develop a glass formers recipe for the waste stream. The recipe uses a mixture of ten different minerals and added sugar as a reductant. The target waste loading for this AN102 glass is nominally $11.8 \mathrm{wt} \% \mathrm{Na}_{2} \mathrm{O}$. This waste loading is lower than the original Specification C Statement of Work target of $\sim 20 \mathrm{wt} \% \mathrm{Na}_{2} \mathrm{O}$ due to the use of a nonsulfate pretreated supernate as feed. The current Modification 014 Specification C Statement of Work specifies a waste loading for Env. C of $>10 \mathrm{wt} \%$ based on $\mathrm{Na}_{2} \mathrm{O}$. Appendix A contains details of the glass recipe provided to SRTC from VSL. The sodium and sulfur target loading in the glass is specified as 11.8 and $0.36 \mathrm{wt} \%$ as $\mathrm{Na}_{2} \mathrm{O}$ and $\mathrm{SO}_{3}$, respectively. The product of these two numbers is 4.248 , which is close to the upper target limit value of 5 . The product of the sodium and sulfur oxide components equal to or less than 5 is referred to as the 'rule of 5' guidance in formulating the sulfatecontaining wastes. This target product value of 5 is an upper limit value and is not strictly used as the actual target value for glass formulation. Concurrence with this particular glass recipe was also obtained from RPP-WTP personnel. The recipe shows that ten different minerals were to be used as the glass former mixture.

\section{Glass Former Blend Preparation and Analysis}

One batch of glass formers was prepared for this study using the recipe for the AN-102 glass supplied by VSL. The blend of glass formers identified as 9382-129 was weighed on a calibrated balance and blended with an automatic shaker for ten minutes. The blend was split into smaller representative samples with a Quantachrome Sieving Rotary Riffler. The riffler device consists of a central container that when filled, is shaken at a high frequency causing the contents to be slowly fed into a rotating tray of eight equal sized stainless steel pans. Splitting a mixture with the riffler device ensures that the resulting portions are representative of the starting batch of material. The glass former blend mixtures were split into $1 / 8^{\text {th }}$ samples and seven samples were recombined. One $1 / 8^{\text {th }}$ sample was split into $1 / 64^{\text {th }}$ samples. A $1 / 64^{\text {th }}$ sample was again split into eight parts for ADS chemical analysis. The glass former blend was prepared as a one-half VSL batch as shown in Table 3. More detailed information on the glass formers used can be found in Reference \#8. 
Table 3.

Glass Former Blend NB\#-9382-129 *

\begin{tabular}{lll} 
Glass Former Identification & $\begin{array}{c}\text { Batch Wt. } \\
\text { (grams) }\end{array}$ & $\begin{array}{c}\text { Actual Wt. } \\
\text { (grams) }\end{array}$ \\
\hline Kyanite, Kyanite Mining. Raw-325 & 65.69 & 65.70 \\
Boric Acid, USBorax, Gran. & 119.76 & 119.79 \\
Wollastonite, NYCO-325, NY & 89.15 & 89.18 \\
Fe2O3, Alfa Aesar, (VSL) & 39.95 & 39.96 \\
Li2CO3, Cyprus Foote & 45.04 & 45.07 \\
Olivine, Unimin, \#180 & 20.93 & 20.98 \\
Silica, US SCS-75, MCOK. & 215.12 & 215.13 \\
Titania, Chemalloy, (VSL) & 7.75 & 7.78 \\
Zinc Oxide, ZCA, (VSL) & 19.95 & 19.95 \\
Zircon Flour, Amer. Miner. (VSL) & 30.86 & 30.86 \\
Sugar, (local) & 10 & $\begin{array}{l}\text { Added Later } \\
\text { Total }\end{array}$ \\
\end{tabular}

*One Half VSL No. AN102 Recipe

The glass former blend was analyzed by SRTC/ADS personnel using $\mathrm{Na}_{2} \mathrm{O}_{2}$ fusion. The analytical data and the calculated blend composition were compared. Table 4 below shows the target weight percent elemental compositions of the blend, the average analyzed elemental compositions and the statistical data indicating percent bias for each result. The percentage difference accounts for the precision in each triplicate analysis vs. the target. In general, the $\mathrm{Na}_{2} \mathrm{O}_{2}$ fusion provided reliable results and all values were found to have a difference of less than $+/-5 \%$ with the exception of zirconium and titanium, which were analyzed to be slightly higher than the target $(8 \%$ and $10 \%$ bias, respectively. These data compare well to previous glass former dissolution data presented in the Env. A, AN-103 technical report for use of $\mathrm{Na}_{2} \mathrm{O}_{2}$ fusion [12]. Other dissolution methods such as Acid dissolution and $\mathrm{CsOH}$ dissolution were not pursued for the Env. C AN-102 glass former batch minerals due to their previous performance in attempts to dissolve the glass former batch minerals in the Env. A, AN-103 work [12]. Previous use of these methods provided low bias results indicating incomplete dissolution of the glass former minerals [12]. 
Table 4. Statistical Analysis Comparing Calculated Glass Former Elemental Composition to Analyzed

9382-129 Batch

\begin{tabular}{llll} 
& & $\mathrm{Na}_{2} \mathrm{O}_{2}$ & \\
& Target & Average & $\%$ \\
Element & $($ Ele.Wt\%) & (of 3), Ele.Wt\% & Difference \\
\hline
\end{tabular}

$\begin{array}{llll}\mathrm{Al} & 2.92 & 2.96 & 1.41 \\ \mathrm{~B} & 3.23 & 3.20 & 1.05 \\ \mathrm{Ca} & 4.66 & 4.78 & 2.68 \\ \mathrm{Cr} & 0.00 & .02 & \\ \mathrm{Fe} & 4.59 & 4.68 & 1.91 \\ \mathrm{Li} & 1.29 & 1.33 & 3.13 \\ \mathrm{Mg} & 0.94 & 0.96 & 2.00 \\ \mathrm{Si} & 22.0 & 22.8 & 3.35 \\ \mathrm{Ti} & 0.78 & 0.83 & 10.0 \\ \mathrm{Zn} & 2.45 & 2.57 & 4.85 \\ \mathrm{Zr} & 2.32 & 2.51 & 8.02\end{array}$

\section{Vitrification}

\section{Mixing of Glass Formers and Waste Streams}

Portions of the glass former batch of minerals were mixed with known volumes of either simulant AN-102 supernate or the active AN-102 pretreated supernate according to the recipe provided for the radioactive AN-102 glass (See Appendix A). The simulant solution recipe is shown in Table 5. This simulant was made to contain only the six salts, $\mathrm{NaOH}, \mathrm{Al}(\mathrm{OH})_{3}, \mathrm{Na}_{2} \mathrm{SO}_{4}, \mathrm{Na}_{2} \mathrm{CO}_{3}, \mathrm{NaNO}_{3}$ and $\mathrm{NaNO}_{2}$. The simulant derives from the previously shown Large $\mathrm{C}$ composite characterization data (See Table 2) and was targeted to be a simple representative salt solution for use as the simulant glass feed.

\section{$\underline{\text { Crucible-Scale Vitrification }}$}

Several crucible-scale vitrification experiments were conducted during the course of this study. Table 6 documents the details of all tests. The initial vitrification Tests \#1 - \#3 involved simulant supernate and were conducted in a Thermolyne furnace capable of $1200^{\circ} \mathrm{C}$ and did not use the sealed quartz offgas system. These tests used a mixed slurry (simulant waste supernate and glass formers and sugar) and used open crucibles in a 
static mode, i.e., no stirring of the crucibles was performed after the initial mixing of supernate and glass formers and sugar. The primary goal of these crucible-scale vitrification tests were to determine if foaming of the slurries within the crucibles during evaporation/calcining was significant, i.e., determine if the material remained completely inside the crucibles during the melt. Initially, we attempted to produce 135 grams of AN102 simulant glass in a $600 \mathrm{~mL}$ crucible. The 135 gram glass target was determined from approximately $1 / 2$ of the total glass made for regulatory analyses in previous Envelope A, AN-103 testing [12]. The Test \#1 was discontinued at about $750^{\circ} \mathrm{C}$ due to excessive overflow of the mixture over the top of the $600-\mathrm{mL}$ crucible. The next Test \#2 attempted produce 120 grams of product glass in the $600-\mathrm{mL}$ crucible. Intermittent observations of the crucible melt in this test indicated some foaming of the contents at levels above the top of the $600-\mathrm{mL}$ crucible. However, the material did not foam over and a product amount of 120.7 grams of glass was produced. Final Test \#3, targeting a product of 110 grams of glass, showed successful containment of the crucible material throughout the melt process. It was thus decided to use the $110 \mathrm{~g}$ glass batch target as the proper crucible loading for the radioactive AN-102 crucible vitrification tests.

Radioactive AN-102 crucible vitrification Tests \#4-\#5 took place in the custom designed Deltech furnace with sealed quartz offgas containment. The target mass of glass shown in the last column of Table 6 derives from the calculated glass mass from the glass former recipe (Appendix A). Table 7 shows the calculated specific activity values expected from blending the specified volume of AN-102 decontaminated supernate ( $86 \mathrm{~mL})$ to make the product glass $(111 \mathrm{~g})$. Average radionuclide values were used from Table 2 composite supernate characterization data.

Figure 3 shows temperature vs. time and condensate volume vs. time plots for the active AN-102 vitrification test. The temperature plot in Figure 3 indicates a slow increase in temperature to $\sim 250{ }^{\circ} \mathrm{C}$, followed by a more rapid temperature increase up to $700{ }^{\circ} \mathrm{C}$. From $700{ }^{\circ} \mathrm{C}$ to $800{ }^{\circ} \mathrm{C}$, the temperature was increased very slowly to prevent overflow of the dried material in the $600 \mathrm{~mL}$ crucible. A rapid increase in temperature was used from $800^{\circ} \mathrm{C}$ to the melt temperature of $1150^{\circ} \mathrm{C}$, followed by 4 hours of melting at 1150 ${ }^{\circ} \mathrm{C}$. Note that the controlled canister cooling segment shown in Figure 3, in the temperature range of $1022^{\circ} \mathrm{C}$ to $400{ }^{\circ} \mathrm{C}$, was maintained to ensure that the actual cooling matched that of the targeted cooling curve previously shown in Figure 2 to within $+/-5^{\circ} \mathrm{C}$ within this $1022{ }^{\circ} \mathrm{C}$ to $400{ }^{\circ} \mathrm{C}$ temperature range. Also note from Figure 3 that no further significant condensate was collected after about 6/20/00 11:30 at the

$\sim 700{ }^{\circ} \mathrm{C}$ temperature, i.e., the condensate volume data shows no further significant increase after this time and temperature. The very initial increase in condensate of about $10 \mathrm{~mL}$ occurring below the $100^{\circ} \mathrm{C}$ temperature range is most likely due to moisture condensing out of the humid air that was pulled though the offgas system by the vacuum. The vacuum was decreased after this initial condensate volume was noticed and the condensate volume remained unchanged until further heatup caused actual evaporation of the slurry sample in the crucible. 
Table 5. Simulant Salt Solution for AN-102 Vitrification Simulant Testing

\begin{tabular}{|c|c|c|}
\hline $\begin{array}{c}\text { Target } \\
\text { Species }\end{array}$ & Concentration & Salt \\
\hline $\mathbf{A l}$ & $\mathbf{m g} / \mathbf{L}$ & \\
\hline $\mathbf{C O}_{3}{ }^{2-}$ & 39,700 & $\mathrm{Al}(\mathrm{OH})_{3}$ \\
\hline $\mathbf{O H}^{-}$ & 21,000 & $\mathrm{Na}{ }_{2} \mathrm{CO}_{3}$ \\
\hline $\mathbf{N O}_{3}{ }^{-}$ & 85,942 & $\mathrm{NaOH}$ \\
\hline $\mathbf{N O}_{2}{ }^{-}$ & 36,218 & $\mathrm{NaNO}$ \\
\hline $\mathbf{N a}$ & 111,514 & $\mathrm{NaNO}_{2}$ \\
\hline $\mathbf{S O}_{4}{ }^{2-}$ & 5,475 & $\mathrm{NaNO}_{2} \mathrm{CO}_{3}, \mathrm{NaNOH}_{2}, \mathrm{Na}_{2} \mathrm{SO}_{4}$ \\
\hline
\end{tabular}


Table 6. Details of Crucible-Scale Vitrification Experiments

\begin{tabular}{|c|c|c|c|c|c|c|}
\hline Test/Date & Date & Furnace & $\begin{array}{c}\text { Mass } \\
\text { Glass } \\
\text { Formers \& } \\
\text { Sugar (g) } \\
\end{array}$ & $\begin{array}{c}\text { Volume } \\
\text { Liquid } \\
\text { (mL) }\end{array}$ & Crucible & $\begin{array}{c}\text { Target } \\
\text { Glass } \\
\text { Mass (g) }\end{array}$ \\
\hline \multicolumn{7}{|l|}{$\begin{array}{c}\text { Simulant } \\
\text { AN102 } \\
\text { Vitrification } \\
\text { Tests } \\
\end{array}$} \\
\hline$\# 1$ & $6 / 13 / 00$ & Thermolyne & $\begin{array}{c}134.5 \\
2 \text { g sugar }\end{array}$ & 106 & $\begin{array}{c}600-\mathrm{mL} \\
\mathrm{Pt} / \mathrm{Au}\end{array}$ & 135 \\
\hline$\# 2$ & $6 / 14 / 00$ & Thermolyne & $\begin{array}{c}119.5 \\
1.8 \mathrm{~g} \text { sugar }\end{array}$ & 94.2 & $\begin{array}{c}600-\mathrm{mL} \\
\mathrm{Pt} / \mathrm{Au}\end{array}$ & $\begin{array}{c}120 \\
\text { Actual }=120.7 \mathrm{~g}\end{array}$ \\
\hline$\# 3$ & $6 / 15 / 00$ & Thermolyne & $\begin{array}{c}109.5 \\
1.65 \mathrm{~g} \mathrm{sugar}\end{array}$ & 86.35 & $\begin{array}{l}\text { 600-mL } \\
\mathrm{Pt} / \mathrm{Au}\end{array}$ & $\begin{array}{c}110 \\
\text { Actual }=110 \mathrm{~g}\end{array}$ \\
\hline \multicolumn{7}{|l|}{$\begin{array}{c}\text { Active AN- } \\
102 \text { Tests }\end{array}$} \\
\hline \#4, & $6 / 18 / 00$ & Deltech & $\begin{array}{c}109.5 \\
1.65 \mathrm{~g} \text { sugar }\end{array}$ & 86 & $\begin{array}{l}600-\mathrm{mL} \\
\mathrm{Pt} / \mathrm{Au}\end{array}$ & 110 \\
\hline$\# 5$, & $6 / 25 / 00$ & Deltech & $\begin{array}{c}109.5 \\
1.65 \mathrm{~g} \text { sugar }\end{array}$ & 86 & $\begin{array}{c}\text { 600-mL } \\
\mathrm{Pt} / \mathrm{Au}\end{array}$ & 110 \\
\hline
\end{tabular}

Table 7. Expected Average Radionuclide Specific Activities in AN-102 Glass

\begin{tabular}{|c|c|c|c|c|}
\hline Radionuclide & $\begin{array}{c}\text { Average } \\
\text { Concentration } \\
\text { (uCi/mL) } \\
\text { (from Table 2) }\end{array}$ & $\begin{array}{c}\text { Volume } \\
\text { Liquid } \\
\text { (mL) }\end{array}$ & $\begin{array}{c}\text { Mass } \\
\text { Glass } \\
\text { (g) }\end{array}$ & $\begin{array}{c}\text { Expected Specific Activity } \\
\text { in Glass } \\
\text { (uCi/g) }\end{array}$ \\
\hline Cs-137 & $5.28 \mathrm{E}-02$ & 86 & 111 & $4.09 \mathrm{E}-02$ \\
\hline Sr-90 & 1.35 & 86 & 111 & 1.04 \\
\hline Tc-99 & $4.72 \mathrm{E}-02$ & 86 & 111 & $3.66 \mathrm{E}-02$ \\
\hline
\end{tabular}


Figure 3. Temperature and Condensate Volumes vs. Time for AN-102 Active Vitrification Tests.

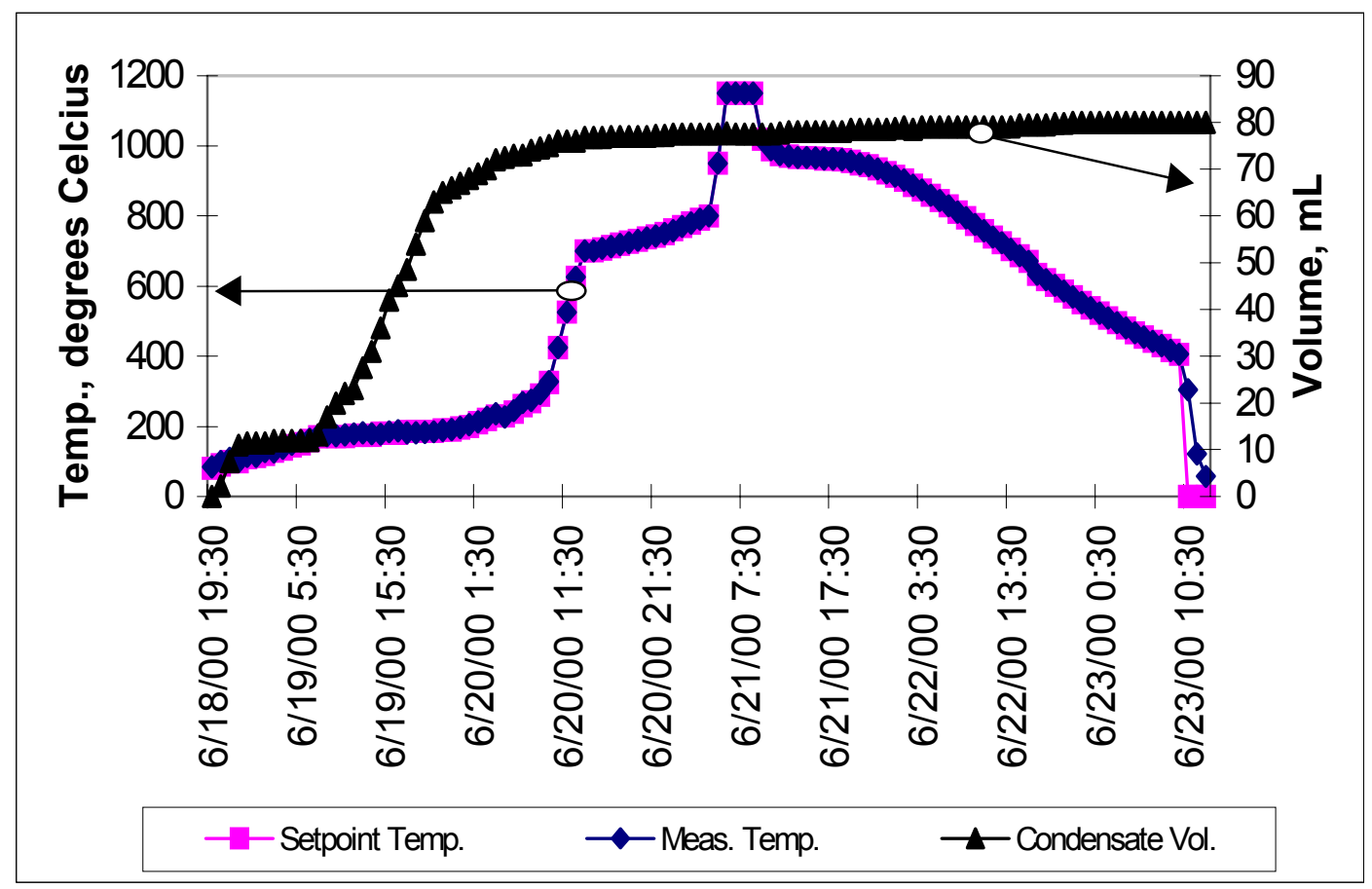




\section{Glass Characterization}

Powdered glass samples of the AN-102 glass were analyzed by XRD and SEM/EDAX analysis. The crushed glass samples were obtained from excess glass that was ground and sieved for the PCT. The results are shown in Appendix B. No crystalline phases were observed in the powdered glass specimens as examined by either XRD or SEM. These analytical results agree with observations of the AN-102 glass by visual inspection that showed the glass to be dark and shiny with no evidence of any secondary phases present. Digital photographs of the top portion of one of the AN-102 glass crucible vitrifications are shown in Figure 4 below. The XRD spectrum of the Envelope C AN102 glass shown in Figure B1 of Appendix B, indicates presence of a peak that is identified as a $\mathrm{Cr} / \mathrm{Fe} / \mathrm{Ni}$ component. This peak is likely due to presence of steel remnants in the powdered glass from use of a tungsten carbide blade grinder with steel compartment. Also, some of the high magnification images and EDAX data indicate presence of steel contaminates in the glass that was prepared for PCT using a tungsten carbide blade grinder with steel compartment (See Figures B6 and B8 of Appendix B). It should be noted that the steel contaminants do not interfere with the PCT since the PCT is carried out in stainless steel vessels. Similar microstructure results to those discussed above for this AN-102 Envelope C glass were reported in the previous SRTC technical report on the AN-103 Envelope A glass [12]. 
Figure 4. Digital Photographs of the AN-102 Crucible Melt
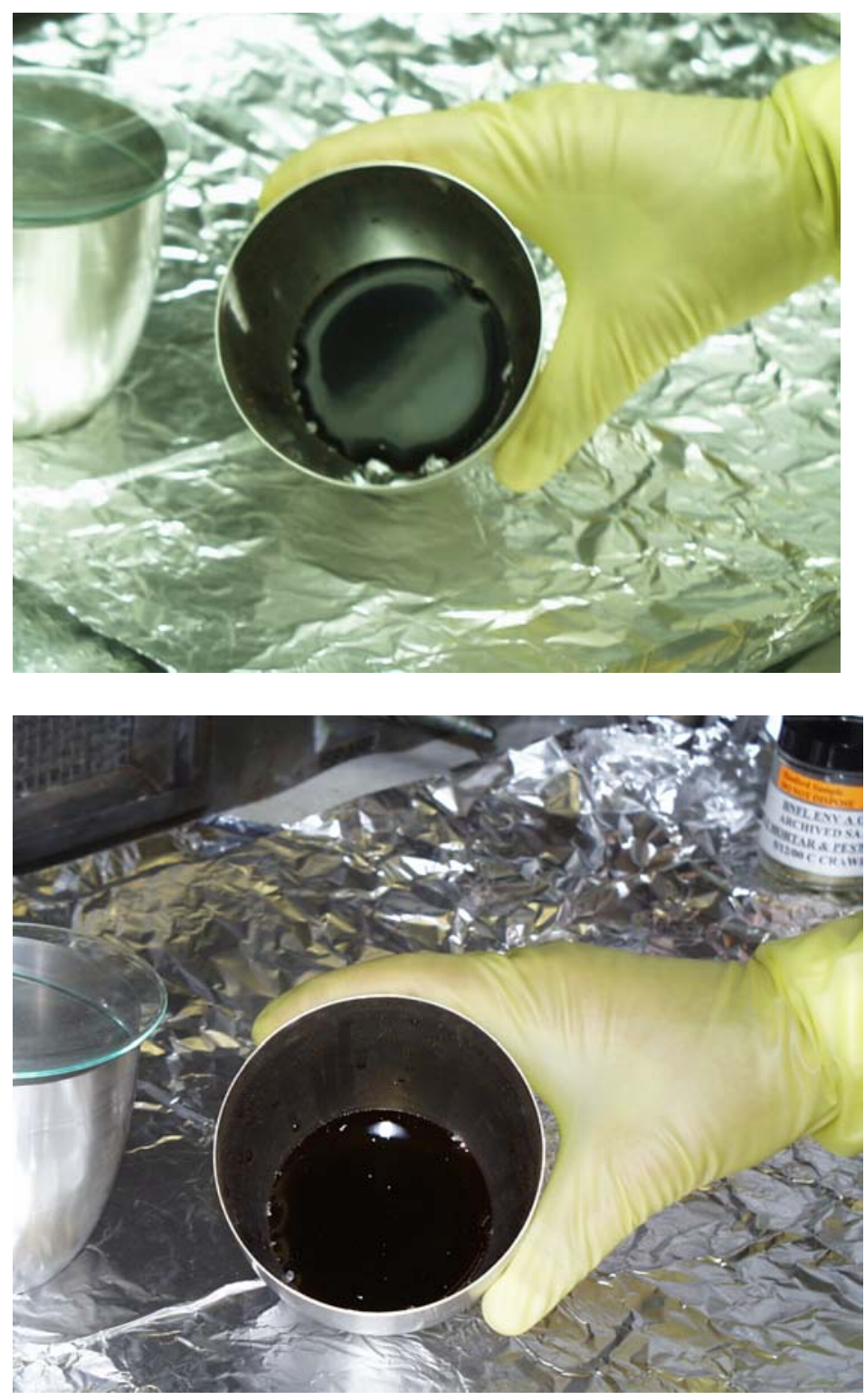

Radioactive AN-102 and the LRM glasses prepared for dissolution for analytical characterization were prepared using an agate ball/mill grinder. Dissolved glasses were analyzed by ICP-ES, AA(K) and Total Uranium methods to determine the inorganic components present in the glass matrix. Results for the two different glasses studied are shown in Table 8 (Radioactive AN-102) and Table 9 (LRM). Oxide values were summed to obtain the totals for all dissolution methods performed on all glasses. As noted in both Tables 8 and 9, sodium and nickel values were indeterminate for the 
peroxide fusion method that used sodium as reagent and were performed in nickel crucibles. Nickel crucibles were also used in the $\mathrm{CsOH}$ fusions. Boric acid was used as reagent in the acid dissolutions preventing boron to be determined in these samples. Note that no analytical values were obtained from the SRTC analyses of the glasses for the elementals $\mathrm{Cl}, \mathrm{F}$ and $\mathrm{S}$. These values were determined in separate Regulatory analyses and are reported in Reference 5 .

Table 8 shows elemental weight percent of all analyzed components in the active AN-102 glass. The elemental values were converted to their oxide components by multiplying by an oxide conversion factor. The target oxide composition shown in Table 8 is taken from the VSL glass recipe discussed earlier (Appendix A). The peroxide fusion data, the $\mathrm{CsOH}$ dissolution data and acid dissolution data were averaged and compared to the target. The last column in Table 8 indicates that the average composition of the glass determined by both peroxide fusion, $\mathrm{CsOH}$ fusion and acid dissolution is within $97 \%$ to $114 \%$ of the target for major elements present in the glass at $0.5 \mathrm{wt} \%$ or more on an oxide basis. This comparison of analyzed oxide to target values is nominally within the $10 \%$ analytical uncertainty of the measurements used to determine the various components in the glass. Elemental analysis was not performed for chlorine, fluorine and sulfur in the glass analyzed in SRTC. Values shown in Table 8 for these elements represent the maximum amounts that could be present from waste feed concentrations.

Table 9 shows similar data for the standard LRM glass. The target oxide composition shown in Table 9 is taken from averaging all of the reported round-robin analytical data reported by Ebert and Wolf [9a]. The peroxide fusion data, the $\mathrm{CsOH}$ data and acid dissolution data were averaged and compared to the target. The last column in Table 9 indicates that the average composition of the glass determined by both peroxide fusion and acid dissolution for major components $>0.5 \mathrm{wt} \%$ as oxide in the glass is within $99 \%$ to $111 \%$ of the target excluding potassium. Previous analysis of the LRM glass [12] indicates better agreement for analyzed K vs. target than the present data. 
Table 8. Elemental and Oxide Composition of Active AN-102 Glass

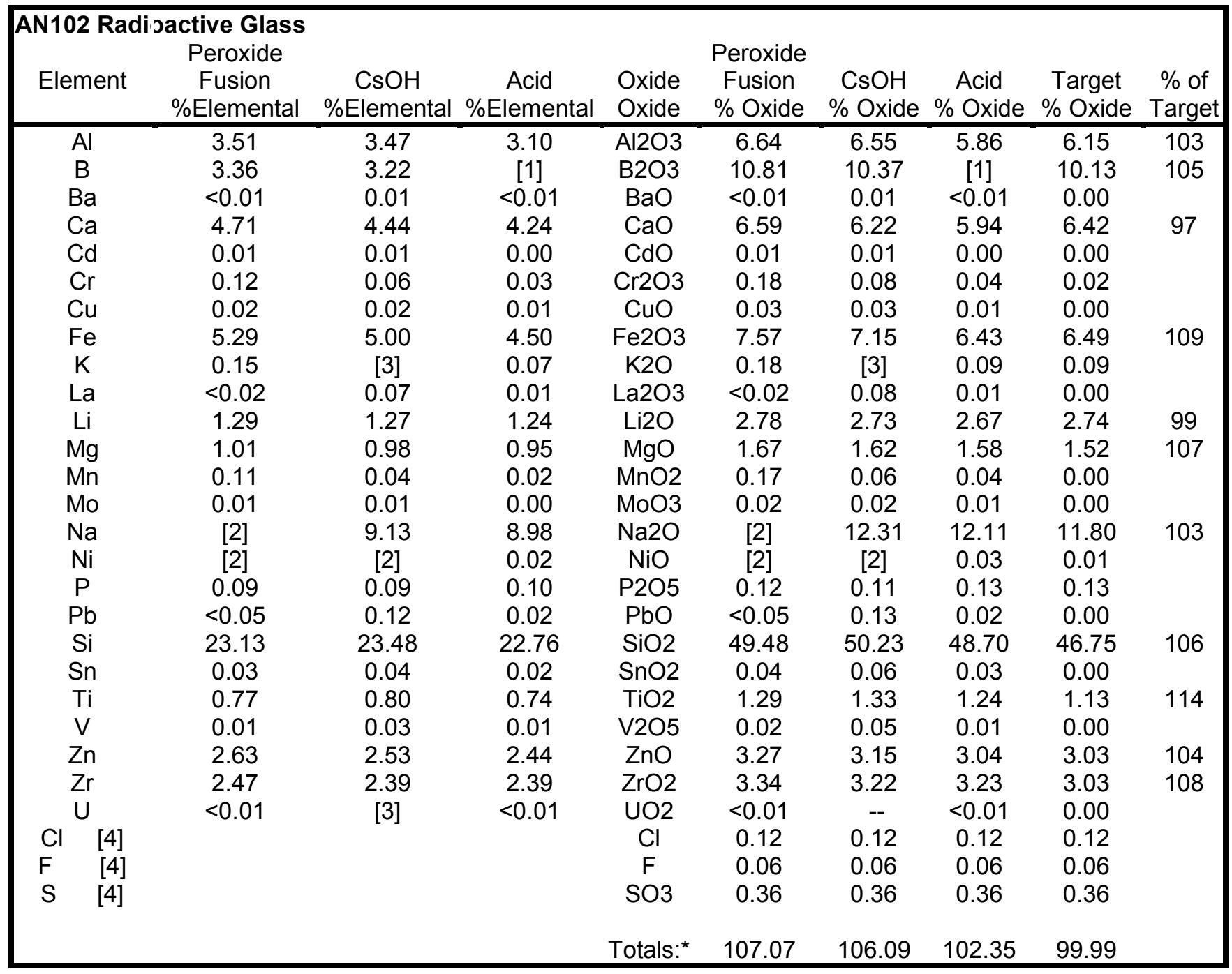

\section{Notes:}

(1) Boric acid used to dilute to mark in acid dissolved glass.

(2) Sodium used in $\mathrm{NaOH} / \mathrm{Na} 2 \mathrm{O} 2$ fusion in $\mathrm{Ni}$-crucibles. Ni-crucibles used in $\mathrm{CsOH}$ fusion.

(3) Total Uranium and potassium not measured in $\mathrm{CsOH}$ dissolved glass.

(4) These and other elements not measured in AN-102 glasses analyzed at SRTC. See Regulatory Analyses Technical Report for analyzed values [5]. Target oxide values for these elements included in oxide Totals.

*Total oxide wt\% values for Peroxide Fusion method calculated by adding average sodium values from $\mathrm{CsOH}$ and Acid methods, and nickel values from Acid Dissolution data. Total oxide wt $\%$ values for $\mathrm{CsOH}$ calculated by adding nickel value from Acid Dissolution data. Total oxide wt\% values for Acid Dissolution method calculated by adding boron value from average of Peroxide Fusion data and $\mathrm{CsOH}$ data. 
Table 9. Elemental and Oxide Composition of LRM Standard Glass

\begin{tabular}{|c|c|c|c|c|c|c|c|c|c|}
\hline \\
\hline Element & $\begin{array}{c}\text { Fusion } \\
\text { \%Elemental }\end{array}$ & $\begin{array}{c}\mathrm{CsOH} \\
\text { \%Elemental }\end{array}$ & $\begin{array}{c}\text { Acid } \\
\% \text { Elemental }\end{array}$ & Oxide & $\begin{array}{l}\text { Fusion } \\
\% \text { Oxide }\end{array}$ & $\begin{array}{c}\mathrm{CsOH} \\
\% \text { Oxide }\end{array}$ & $\begin{array}{c}\text { Acid } \\
\% \text { Oxide }\end{array}$ & $\begin{array}{c}\text { Target } \\
\% \text { Oxide }\end{array}$ & $\begin{array}{c}\% \text { of } \\
\text { Target }\end{array}$ \\
\hline $\mathrm{Al}$ & 5.00 & 5.48 & 4.83 & $\mathrm{Al} 2 \mathrm{O} 3$ & 9.45 & 10.35 & 9.13 & 9.54 & 101 \\
\hline B & 2.39 & 2.53 & [1] & B2O3 & 7.71 & 8.15 & [1] & 7.90 & 100 \\
\hline $\mathrm{Ba}$ & $<0.01$ & 0.01 & $<0.01$ & $\mathrm{BaO}$ & $<0.01$ & 0.01 & $<0.01$ & 0.00 & \\
\hline $\mathrm{Ca}$ & 0.37 & 0.41 & 0.36 & $\mathrm{CaO}$ & 0.52 & 0.58 & 0.50 & 0.54 & 99 \\
\hline $\mathrm{Cd}$ & 0.15 & 0.15 & 0.14 & $\mathrm{CdO}$ & 0.17 & 0.18 & 0.16 & 0.16 & \\
\hline $\mathrm{Cr}$ & 0.17 & 0.19 & 0.14 & Cr2O3 & 0.25 & 0.28 & 0.20 & 0.19 & \\
\hline $\mathrm{Cu}$ & 0.01 & 0.01 & 0.06 & $\mathrm{CuO}$ & 0.01 & 0.01 & 0.08 & [5] & \\
\hline $\mathrm{Fe}$ & 1.03 & 1.11 & 0.97 & $\mathrm{Fe} 2 \mathrm{O} 3$ & 1.48 & 1.59 & 1.39 & 1.42 & 105 \\
\hline $\mathrm{K}$ & 1.04 & [3] & 0.94 & $\mathrm{~K} 2 \mathrm{O}$ & 1.25 & [3] & 1.13 & 1.48 & 80 \\
\hline $\mathrm{La}$ & $<0.10$ & 0.04 & 0.01 & La2O3 & $<0.12$ & 0.05 & 0.01 & 0.02 & \\
\hline $\mathrm{Li}$ & 0.05 & 0.05 & 0.05 & $\mathrm{Li} 2 \mathrm{O}$ & 0.10 & 0.12 & 0.10 & 0.11 & \\
\hline $\mathrm{Mg}$ & 0.06 & 0.07 & 0.06 & $\mathrm{MgO}$ & 0.10 & 0.12 & 0.11 & 0.10 & \\
\hline $\mathrm{Mn}$ & 0.10 & 0.07 & 0.06 & $\mathrm{MnO} 2$ & 0.16 & 0.11 & 0.09 & 0.08 & \\
\hline Mo & 0.10 & 0.08 & 0.07 & MoO3 & 0.15 & 0.11 & 0.10 & 0.10 & \\
\hline $\mathrm{Na}$ & [2] & 16.14 & 15.02 & $\mathrm{Na} 2 \mathrm{O}$ & [2] & 21.76 & 20.24 & 20.03 & 105 \\
\hline $\mathrm{Ni}$ & [2] & [2] & 0.15 & $\mathrm{NiO}$ & [2] & [2] & 0.19 & 0.19 & \\
\hline $\mathrm{P}$ & 0.24 & 0.26 & 0.27 & P2O5 & 0.55 & 0.59 & 0.62 & 0.53 & 111 \\
\hline $\mathrm{Pb}$ & $<0.23$ & 0.17 & 0.10 & $\mathrm{PbO}$ & $<0.25$ & 0.18 & 0.11 & 0.10 & \\
\hline $\mathrm{Si}$ & 24.79 & 28.01 & 25.64 & $\mathrm{SiO} 2$ & 53.04 & 59.92 & 54.84 & 54.26 & 106 \\
\hline Sn & $<0.42$ & 0.03 & 0.02 & $\mathrm{SnO} 2$ & 0.54 & 0.04 & 0.03 & 0.03 & \\
\hline $\mathrm{Ti}$ & 0.07 & 0.07 & 0.06 & $\mathrm{TiO} 2$ & 0.12 & 0.12 & 0.10 & 0.11 & 109 \\
\hline V & $<0.01$ & $<0.01$ & $<0.01$ & V2O5 & $<0.02$ & $<0.02$ & $<0.00$ & [5] & \\
\hline $\mathrm{Zn}$ & 0.05 & 0.01 & 0.02 & $\mathrm{ZnO}$ & 0.06 & 0.02 & 0.02 & [5] & \\
\hline $\mathrm{Zr}$ & 0.71 & 0.78 & 0.75 & ZrO2 & 0.96 & 1.06 & 1.02 & 0.93 & 109 \\
\hline U & $<0.01$ & [3] & $<0.01$ & UO2 & $<0.01$ & [3] & $<0.01$ & 0.00 & \\
\hline $\mathrm{Cl}$ [4] & & & & $\mathrm{Cl}$ & 0.80 & 0.80 & 0.80 & 0.80 & 100 \\
\hline$F[4]$ & & & & $\mathrm{F}$ & 1.00 & 1.00 & 1.00 & 1.00 & 100 \\
\hline$S$ [4] & & & & $\mathrm{SO} 3$ & 0.20 & 0.20 & 0.20 & 0.20 & 100 \\
\hline & & & & Totals:* & 100.18 & 107.55 & 100.11 & 99.80 & \\
\hline
\end{tabular}

\section{Notes:}

(1) Boric acid used to dilute to mark in acid dissolved glass.

(2) Sodium used in $\mathrm{NaOH} / \mathrm{Na} 2 \mathrm{O} 2$ fusion in Ni-crucibles. Ni-crucibles used in $\mathrm{CsOH}$ fusion.

(3) Potassium and Total Uranium not measured in $\mathrm{CsOH}$ dissolved glass.

(4) These and other elements not measured in AN-102 glasses analyzed at SRTC. See Regulatory Analyses

Technical Report for analyzed values [5]. Target oxide values for these elements included in oxide Totals.

(5) Components not added to LRM glass, See reference 9a.

*Total oxide wt $\%$ values for Peroxide Fusion method calculated by adding average sodium values from $\mathrm{CsOH}$ and Acid methods, and nickel values from Acid Dissolution data. Total oxide wt $\%$ values for $\mathrm{CsOH}$ calculated by adding nickel value from Acid Dissolution data. Total oxide wt\% values for Acid Dissolution method calculated by adding boron value from average of Peroxide Fusion data and $\mathrm{CsOH}$ data. 
Dissolved glasses were analyzed by various radiochemical methods indicated in Table 1 shown previously. All reported analytical data is shown in Table 10 for the glasses dissolved by peroxide fusion. Similar data is shown in Table 11 for glasses dissolved by acid dissolution. All results were reported in units of $\mathrm{dpm} / \mathrm{mL}$ for these samples. These values were converted to specific activities of radionuclides in the glasses $(\mu \mathrm{Ci} / \mathrm{g}$ glass) using Equation 2 below:

\section{Equation 2:}

$\mathrm{dpm} / \mathrm{mL} \times(\mathrm{mL} /$ grams glass $) \times(1 \mathrm{~min} / 60 \mathrm{~s}) \times(1 \mathrm{Ci} / 3.7 \mathrm{E}+10 \mathrm{dps}) \times 1 \mathrm{E}+06 \mu \mathrm{Ci} / 1 \mathrm{Ci}$

The exact amounts of each glass weighed out in the dissolution process to produce the $100-\mathrm{mL}$ solutions are noted at the bottom of Tables 10 and 11. All radionuclide values reported in Tables 10 and 11 were analyzed directly except for Y-90 and Ba-137m. Yttrium-90 (half-life $=2.671$ days) is a decay product of Sr-90 (half-life $=28.5$ years) and is in secular equilibrium with Sr-90. Thus the concentration of this short-lived Y-90 daughter-product is equal to Sr-90. Barium- $137 \mathrm{~m}$ is a metastable decay product of $\mathrm{Cs}-137$ and is in secular equilibrium with Cs-137. The activity of Ba-137m is $95 \%$ of that for Cs-137 since 5\% of the Cs-137 decays directly to stable Ba-137.

Tables 10 and 11 indicate that Strontium-90 and Yyttrium-90 are the predominant radionuclides in the active $\mathrm{AN}-102$ glass at about $1 \mu \mathrm{Ci} / \mathrm{g}$ levels. Cesium-137 and Ba$137 \mathrm{~m}$ and Tc-99 are present at nominally much lower specific activities $(\sim 0.02$ to $\sim 0.03$ $\mu \mathrm{Ci} / \mathrm{g})$ in the active $\mathrm{AN}-102$ glass. Conversion of the tabulated radionuclide values from units of $\mu \mathrm{Ci} / \mathrm{g}$ glass to $\mathrm{Ci} / \mathrm{m}^{3}$ can be calculated using the measured density of both the Env. C glass $=2.87 \mathrm{~g} / \mathrm{cm}^{3}$ (Reference 5 ) and LRM glass $=2.52 \mathrm{~g} / \mathrm{cm}^{3}$ (Reference $9 \mathrm{~b}$ ) per Equation 3 below.

\section{Equation 3:}

Env. C glass:

$1 \mu \mathrm{Ci} / \mathrm{g} \times 2.87 \mathrm{~g} / \mathrm{cm}^{3}$ x $1 \mathrm{Ci} / 1 \mathrm{E}+06 \mu \mathrm{Ci} \times(100 \mathrm{~cm} / 1 \mathrm{~m})^{3}=2.87 \mathrm{Ci} / \mathrm{m}^{3}$

LRM glass:

$1 \mu \mathrm{Ci} / \mathrm{g} \times 2.52 \mathrm{~g} / \mathrm{cm}^{3} \times 1 \mathrm{Ci} / 1 \mathrm{E}+06 \mu \mathrm{Ci} \times(100 \mathrm{~cm} / 1 \mathrm{~m})^{3}=2.52 \mathrm{Ci} / \mathrm{m}^{3}$

Section C, Specification 2.2.2.8 of the RPP-WTP-DOE/ORP contract indicates that average radionuclide concentration limitations shall be less than $3 \mathrm{Ci} / \mathrm{m}^{3}$ for $\mathrm{Cs}-137,<20$ $\mathrm{Ci} / \mathrm{m}^{3}$ for $\mathrm{Sr}-90$ and $<0.1 \mathrm{Ci} / \mathrm{m}^{3}$ for Tc-99 for the ILAW glasses[1]. The average cesium concentration as design basis is actually $0.3 \mathrm{Ci} / \mathrm{m}^{3}$. Per communication with Mike Johnson of RPP/WTP, this latter value of $0.3 \mathrm{Ci} / \mathrm{m}^{3}$ is the more recent design basis value put in place to reduce the level of shielding needed in a LAW vitrification plant. 
Consideration of previous Table 7 data for estimated values of the Cs-137, Sr-90 and Tc99 radionuclides in the AN-102 glass and analyzed data from Tables 10 and 11 indicate these radionuclide levels are below the specified limits for the LAW Envelope $\mathrm{C}$ glass. Analyzed values for these radionuclides presented in Tables 10 and 11 are near the estimated values from Table 7. Analyzed values for Cs-137 and Sr-90 give better agreement vs. estimated values than does the analyzed Tc-99 values vs. estimated values. Analyzed values for Tc-99 were somewhat lower than the value estimated from the feed Tc-99 concentration. Volatilization during open-crucible vitrification or during aggressive glass dissolutions (peroxide fusion and acid digestion) could account for this observation. A singular value for Tc-99 (radiochemical counting value of $1.6 \mathrm{E}-01 \mu \mathrm{Ci} / \mathrm{g}$ from Table 11 acid dissolved glass) is an order of magnitude higher than all other reported radiochemical and mass spectral values for the AN-102 glass. Comparison of this Tc-99 value with the predicted value from Table $7(3.66 \mathrm{E}-02 \mu \mathrm{Ci} / \mathrm{g})$ also indicates that this value is likely inaccurate. One explanation for this high Tc-99 analyzed value could be interference from the relatively higher amounts of the beta decaying Sr and $\mathrm{Y}$ radionuclides present in the glass. It was noted in the radiochemical analysis of this sample that evidence of non-Tc-99 beta energies were present, which would contribute to the high bias value in this case.

Conversion of the units shown in Table 10 and Table 11 as $\mu \mathrm{Ci} / \mathrm{g}$ to units of $\eta \mathrm{Ci} / \mathrm{g}$ indicates that the transuranic (TRU) content of the AN-102 glass samples is $\sim 22 \eta \mathrm{Ci} / \mathrm{g}$ measured total alpha $(0.022 \mu \mathrm{Ci} / \mathrm{g})$, or $\sim 24 \mathrm{\eta Ci} / \mathrm{g}(0.024 \mu \mathrm{Ci} / \mathrm{g})$ from summation of the $\mathrm{Pu}-238,239$ and 240, Am-241 and Cm-244 isotope alpha-emitters. These values are at least $4 \mathrm{X}$ lower than the DOE/ORP contract limit of $100 \eta \mathrm{Ci} / \mathrm{g}$ [1]. Similarly, Table 11 shows that the TRU content of the AN-102 glass sample is $\sim 22 \eta \mathrm{Ci} / \mathrm{g}$ measured total alpha, or $\sim 20 \eta \mathrm{Ci} / \mathrm{g}$ from summation of the $\mathrm{Pu} / \mathrm{Am} / \mathrm{Cm}$ alpha-emitters. According to the Code of Federal Regulations (CRF) (10 CFR 61.56, Waste Classification, Table 1), a limit of 3,500 $\mathrm{\eta Ci} / \mathrm{g}$ is provided for the beta-emitter radioisotope $\mathrm{Pu}-241$. Both Tables 10 and 11 indicate that $\mathrm{Pu}-241$ was not detected in either dissolved AN-102 glass to the detection level of $<2.9 \eta \mathrm{Ci} / \mathrm{g}$. Overall agreement between various radionuclides analyzed by peroxide fusion (Table 10) and acid dissolution (Table 11) is very good. 
Table 10. Radionuclide Analyses for Peroxide Fusion Dissolved Glasses

Radionuclide Analyses for Peroxide Fusion Dissolved Glasses

\begin{tabular}{|c|c|c|c|c|c|c|c|c|c|c|}
\hline \multirow{2}{*}{$\mid$\begin{tabular}{l|l} 
& \\
\end{tabular}} & \multirow{2}{*}{\multicolumn{2}{|c|}{ D }} & \multirow{2}{*}{\multicolumn{2}{|c|}{ a }} & \multirow{2}{*}{ (2) } & & & & \multirow{3}{*}{ t Blank } \\
\hline & & & & & & & & & & \\
\hline Radionuclide & \multicolumn{3}{|c|}{ AN-102 Radioactive } & & \multicolumn{2}{|c|}{ LRM Standard } & & & Reagent Blank & \\
\hline & Glass & & & & Glass & & & & & \\
\hline & $(\mathrm{dpm} / \mathrm{mL})$ & (uCi/g) & $\mathrm{Ci} / \mathrm{m}^{3 \#}$ & & $(\mathrm{dpm} / \mathrm{mL})$ & $(\mathrm{uCi} / \mathrm{g}$ & $\mathrm{Ci} / \mathrm{m}^{3 \#}$ & & $(\mathrm{dpm} / \mathrm{mL})$ & (uCi/mL) \\
\hline Total Alpha & 241 & 2.17E-02 & $6.23 \mathrm{E}-02$ & $\mid<$ & 6.62 & 5.93E-04 & $149 \mathrm{E}-03$ & $<$ & 51 & $2.03 \mathrm{E}-06$ \\
\hline Total Beta & $3.54 \mathrm{E}+04$ & $3.19 \mathrm{E}+00$ & $9.15 E+00$ & $<$ & 202 & 1.81E-02 & $4.56 \mathrm{E}-02$ & $<$ & 13.5 & $6.08 \mathrm{E}-06$ \\
\hline Sr-90 & $1.27 E+04$ & $1.14 \mathrm{E}+00$ & $3.28 \mathrm{E}+00$ & $<$ & 65.2 & 5.84E-03 & $1.47 \mathrm{E}-02$ & $<$ & 65.2 & 2.94E-05 \\
\hline Estimated \#\# & & 1.04 & & & & & & & & \\
\hline $\mathrm{Y}-90$ & $1.27 E+04$ & $1.14 \mathrm{E}+00$ & $3.28 \mathrm{E}+00$ & $<$ & 65 & 5.84E-03 & 1.47E-02 & $<$ & 65.2 & 2.94E-05 \\
\hline Tc-99 & 137 & 1.23E-02 & $3.54 \mathrm{E}-02$ & $<$ & 6.38 & 5.72E-04 & 1.44E-03 & & 16.4 & 7.39E-06 \\
\hline Tc-99(ICP-MS) & $5.4 \mathrm{ug} / \mathrm{L}$ & 1.83E-02 & $5.26 \mathrm{E}-02$ & $<$ & 0.09 & 3.04E-04 & $7.65 \mathrm{E}-04$ & $<$ & 0.08 & 1.36E-06 \\
\hline Estimated \#\# & & $3.66 \mathrm{E}-02$ & & & & & & & & \\
\hline $\mathrm{Pu}-238$ & 7.16 & $6.45 \mathrm{E}-04$ & $1.85 \mathrm{E}-03$ & $<$ & 0.556 & $4.98 \mathrm{E}-05$ & 1.26E-04 & $<$ & 2.64 & 1.19E-06 \\
\hline $\mathrm{Pu}-239 / 240$ & 3.57 & 3.22E-04 & $9.23 \mathrm{E}-04$ & $<$ & 6.2 & 5.55E-04 & $1.40 \mathrm{E}-03$ & $<$ & 1.05 & 4.73E-07 \\
\hline Pu-241 & -- & 2.92E-03 & 4.19E-05 & $<$ & - & $3.38 \mathrm{E}-03$ & $4.28 \mathrm{E}-05$ & $<$ & -- & $1.26 \mathrm{E}-05$ \\
\hline Am-241 & 157.0 & 1.41E-02 & $4.06 \mathrm{E}-02$ & & 13.5 & 1.21E-03 & 3.05E-03 & & 8.39 & $3.78 \mathrm{E}-06$ \\
\hline $\mathrm{Cm}-244$ & 99.7 & 8.98E-03 & $2.58 \mathrm{E}-02$ & & 45 & $4.03 E-03$ & 1.02E-02 & & 9.62 & $4.33 \mathrm{E}-06$ \\
\hline $\begin{array}{c}\text { Gamma } \\
\text { Spectroscopy }\end{array}$ & & & & & & & & & & \\
\hline Cs-137 & $3.82 \mathrm{E}+02$ & 3.44E-02 & $9.89 \mathrm{E}-02$ & $<$ & 48.6 & $4.35 \mathrm{E}-03$ & 1.10E-02 & $<$ & 30.1 & 1.36E-05 \\
\hline Estimated \#\# & & 4.09E-02 & & & & & & & & \\
\hline Ba-137m & $3.63 E+02$ & 3.27E-02 & 9.39E-02 & $<$ & 46.2 & 4.14E-03 & 1.04E-02 & $<$ & 28.6 & 1.29E-05 \\
\hline Co-60 & $3.80 \mathrm{E}+02$ & $3.42 \mathrm{E}-02$ & 9.83E-02 & $\mid<1$ & 12.6 & 1.13E-03 & 2.84E-03 & $\|<$ & 48.5 & $2.18 \mathrm{E}-05$ \\
\hline
\end{tabular}

AN-102 Radioactive Glass $=$ ADS $\# 717=0.4999$ grams in $0.1 \mathrm{~L}$

LRM Standard Glass $=$ ADS $\# 720=0.5028$ grams in $0.1 \mathrm{~L}$

Notes:

\# Specification limits (Reference 1): $<3 \mathrm{Ci} / \mathrm{m}^{3}$ for $\mathrm{Cs}-137,<20 \mathrm{Ci} / \mathrm{m}^{3}$ for $\mathrm{Sr}-90$ and $<0.1 \mathrm{Ci} / \mathrm{m}^{3}$ for Tc-99; Densities used for Env. C glass $\left(2.87 \mathrm{~g} / \mathrm{cm}^{3}\right)$ and LRM glass $\left(2.52 \mathrm{~g} / \mathrm{cm}^{3}\right)$ from References 5 and $9 \mathrm{~b}$, respectively.

\#\# Estimated values from Table 7.

† Tc-99 ICPMS Instrument Detection Limit (IDL) $=0.02 \mathrm{ug} / \mathrm{L}$ for non-diluted sample; ICPMS values for Tc-99 in $\mathrm{ug} / \mathrm{L}$ converted to $\mathrm{uCi} / \mathrm{g}$ in glass using the mass and volume data shown at bottom of Table 10 and using Equation 1. 
Table 11. Radionuclide Analyses for Acid Dissolved Glasses

Radionuclide Analyses for Acid Dissolved Glasses

\begin{tabular}{|c|c|c|c|c|c|c|c|c|c|c|c|}
\hline \multirow{2}{*}{\multicolumn{12}{|c|}{ |l| }} \\
\hline & & & & & & & & & & & \\
\hline Radionuclide & & \multicolumn{2}{|c|}{ AN-102 Radioactive } & & & \multicolumn{2}{|c|}{ LRM Standard } & & & \multicolumn{2}{|c|}{ Reagent Blank } \\
\hline & & Glass & & & & Glass & & & & & \\
\hline & & $(\mathrm{dpm} / \mathrm{mL})$ & (uCi/g) & $\mathrm{Ci} / \mathrm{m}^{3 \#}$ & & $(\mathrm{dpm} / \mathrm{mL})$ & (uCi/g) & $\mathrm{Ci} / \mathrm{m}^{3 \#}$ & & (dpm/mL) & (uCi/mL) \\
\hline Total Alpha & & 248.0 & $2.22 \mathrm{E}-02$ & 6.37E-02 & $<$ & 5.6 & $5.05 \mathrm{E}-04$ & $127 \mathrm{E}-03$ & $<$ & 5.9 & $2.68 \mathrm{E}-06$ \\
\hline Total Beta & & $3.38 \mathrm{E}+04$ & $3.03 E+00$ & $8.68 \mathrm{E}+00$ & $<$ & 14.3 & $1.29 \mathrm{E}-03$ & $3.25 \mathrm{E}-03$ & $\mid<$ & 14 & $6.44 \mathrm{E}-06$ \\
\hline Sr-90 & & $1.21 \mathrm{E}+04$ & $1.08 \mathrm{E}+00$ & $3.11 \mathrm{E}+00$ & $<$ & 65.2 & $5.88 \mathrm{E}-03$ & $1.48 \mathrm{E}-02$ & $<$ & 65.2 & $2.94 \mathrm{E}-05$ \\
\hline Estimated \#\# & & & 1.04 & & & & & & & & \\
\hline$Y-90$ & & $1.21 \mathrm{E}+04$ & $1.08 \mathrm{E}+00$ & $3.11 \mathrm{E}+00$ & $<$ & 65.2 & $5.88 \mathrm{E}-03$ & $1.48 \mathrm{E}-02$ & $<$ & 65.2 & $2.94 \mathrm{E}-05$ \\
\hline Tc-99 & $<$ & 1820 & 1.63E-01 & $4.68 \mathrm{E}-01$ & $<$ & 3.91 & $3.52 \mathrm{E}-04$ & 8.88E-04 & & 3.92 & 1.77E-06 \\
\hline Tc-99(ICP-MS) † & & $4.9 \mathrm{ug} / \mathrm{L}$ & 1.65E-02 & 4.74E-02 & $<$ & 0.43 & $1.46 \mathrm{E}-03$ & 3.68E-03 & $<$ & 0.42 & $7.13 \mathrm{E}-06$ \\
\hline Estimated \#\# & & & $3.66 \mathrm{E}-02$ & & & & & & & & \\
\hline $\mathrm{Pu}-238$ & $<$ & 7.16 & $6.41 \mathrm{E}-04$ & 1.84E-03 & $<$ & 0.849 & $7.65 \mathrm{E}-05$ & 1.93E-04 & $<$ & 0.07 & $3.15 \mathrm{E}-08$ \\
\hline Pu-239/240 & $<$ & 3.57 & $3.20 \mathrm{E}-04$ & 9.17E-04 & $<$ & 0.351 & $3.16 \mathrm{E}-05$ & 7.97E-05 & $<$ & 0.0183 & $8.24 \mathrm{E}-09$ \\
\hline $\mathrm{Pu}-241$ & $<$ & & $2.90 \mathrm{E}-03$ & 8.32E-03 & $<$ & & $1.72 \mathrm{E}-03$ & 4.33E-03 & $<$ & & $5.78 \mathrm{E}-06$ \\
\hline Am-241 & & 136 & $1.22 \mathrm{E}-02$ & $3.49 \mathrm{E}-02$ & $<$ & 19.8 & $1.78 \mathrm{E}-03$ & 4.50E-03 & $<$ & 12.1 & $5.45 \mathrm{E}-06$ \\
\hline $\mathrm{Cm}-244$ & & 82.40 & $7.38 \mathrm{E}-03$ & $2.12 \mathrm{E}-02$ & $<$ & 6.98 & $6.29 \mathrm{E}-04$ & 1.59E-03 & $<$ & 8.76 & $3.95 \mathrm{E}-06$ \\
\hline $\begin{array}{c}\text { Gamma } \\
\text { Spectroscopy }\end{array}$ & & & & & & & & & & & \\
\hline Cs-137 & & $3.77 \mathrm{E}+02$ & $3.38 \mathrm{E}-02$ & 9.70E-02 & $<$ & 45.7 & 4.12E-03 & 1.04E-02 & $<$ & 51.4 & $2.32 \mathrm{E}-05$ \\
\hline Estimated \#\# & & & $4.09 \mathrm{E}-02$ & & & & & & & & \\
\hline Ba-137m & & $3.59 \mathrm{E}+02$ & $3.21 \mathrm{E}-02$ & 9.21E-02 & $<$ & 43.4 & 3.91E-03 & 9.86E-03 & $<$ & 48.8 & $2.20 \mathrm{E}-05$ \\
\hline Co-60 & & $3.59 \mathrm{E}+02$ & $3.21 \mathrm{E}-02$ & $9.23 \mathrm{E}-02$ & $<1$ & 43.4 & 3.91E-03 & 9.86E-03 & $\mid<1$ & 56.1 & $2.53 E-05$ \\
\hline
\end{tabular}

AN-102 Radioactive Glass $=$ ADS\#709 $=0.5032$ grams in $0.1 \mathrm{~L}$

LRM Standard Glass = ADS\#712 $=0.4997$ grams in $0.1 \mathrm{~L}$

Notes:

\# Specification limits (Reference 1): $<3 \mathrm{Ci} / \mathrm{m}^{3}$ for $\mathrm{Cs}-137,<20 \mathrm{Ci} / \mathrm{m}^{3}$ for $\mathrm{Sr}-90$ and $<0.1 \mathrm{Ci} / \mathrm{m}^{3}$ for Tc-99; Densities used for Env. C glass $\left(2.87 \mathrm{~g} / \mathrm{cm}^{3}\right)$ and LRM glass $\left(2.52 \mathrm{~g} / \mathrm{cm}^{3}\right)$ from References 5 and $9 \mathrm{~b}$, respectively.

\#\# Estimated values from Table 7.

† Tc-99 ICPMS Instrument Detection Limit (IDL) $=0.02 \mathrm{ug} / \mathrm{L}$ for non-diluted sample; ICPMS values for Tc-99 in ug/L converted to $\mathrm{uCi} / \mathrm{g}$ in glass using the mass and volume data shown at bottom of Table 11 and using Equation 1. 


\section{Results of 'Association of Standards and Test Methods' (ASTM) Test C 1285 - 97 Leach Test 'Product Consistency Test' (PCT) on AN-102 ILAW Glass}

The two tables in this section show the results of the standard ASTM C 1285 -97 test on the radioactive AN-102 glass. This test is commonly called the Product Consistency Test (PCT) and is performed at $90^{\circ} \mathrm{C}$ [11]. The procedure for PCT-A of the ASTM C 1285-97 was strictly followed for this test. Triplicate samples of the AN-102 glass and, as prescribed by the procedure, triplicate blanks were used. The standard glasses, Low Activity Reference Material (LRM) [9,10] and Analytical Reference Material (ARM) [14] were also leached in the test with the AN-102 glass.

In the contract, SRTC was required to subject the AN-102 glass to the PCT and report the results for $\mathrm{B}, \mathrm{Si}$, and $\mathrm{Na}$ for the AN-102 glass. Section 2.2.2.17.2 of Mod. No. M013 of the contract specifies that in the PCT, the glass shall have a normalized mass loss less than $2 \mathrm{~g} / \mathrm{m}^{2}$ ( 2 grams of glass per square meter of exposed surface area of glass tested in a $90^{\circ} \mathrm{C} \mathrm{PCT}$ ) based on each of the elements B, Si, and Na. The LRM [9,10], and the standard (ARM) glass [14] were also tested with the AN-102 glass to confirm that the test conditions for the PCT were properly controlled. Table 12 gives the average concentrations in ppm of $\mathrm{B}, \mathrm{Si}$, and $\mathrm{Na}$, in the final leachates after the tests. The averages of the final $\mathrm{pH}$ values of the leachates are also presented. The concentrations have been corrected for the acidification dilutions of the leachates as required by the ASTM procedure. The raw data that is the bases of these averages are in Appendix C. The last row of the table presents the consensus results of the PCT of a round robin on the LRM glass involving six different laboratories [10]. As can be seen, the concentrations measured in this test for LRM glass were very close to the consensus concentrations.

Table 12. Average Concentrations (ppm) of $\mathrm{B}, \mathrm{Si}$, and $\mathrm{Na}$, and the Final $\mathrm{pH}$ from the $90^{\circ} \mathrm{C} \mathrm{PCT}$.

\begin{tabular}{|c|c|c|c|c|}
\hline Sample ID & B & Si & Na & pH (b) \\
\hline Blanks(a) & 0.029 & 0.046 & 0.318 & 6.66 \\
\hline ARM(a) & 18.3 & 65.5 & 38.7 & 10.2 \\
\hline AN-102(a) & 19.4 & 57.1 & 62.9 & 10.6 \\
\hline LRM(a) & 25.4 & 80.1 & 160.8 & 10.8 \\
\hline LRM(c) & 26.7 & 82.0 & 159.7 & 11.7 \\
\hline
\end{tabular}

(a) Based on triplicate tests.

(b) Initial $\mathrm{pH}$ of the leach water was 6.57

(c) Published consensus values for LRM glass. [10]

The results for the blanks indicate that contamination of the leachates from possible impurities in the water or on the stainless steel vessels was negligible. The results for the standard ARM-1 glass were compared to a control chart based on results for previous 
Product Consistency Tests on this standard glass [15]. This comparison is part of the ASTM procedure. The results were between the lower and upper control limits (See Appendix $\mathrm{C}$ for PCT data sheet on ARM glass) indicating that all the test conditions were properly controlled. Standard solutions containing $\mathrm{B}, \mathrm{Si}$, and $\mathrm{Na}$ were submitted for analysis with the leachates. The measured results agreed within $10 \%$ of the known values (see Appendix C) indicating that the analyses were sufficiently accurate. Thus the results of the PCT are acceptable.

The final $\mathrm{pH}$ is an approximate indication of the durability of the glass in a PCT. The higher the final $\mathrm{pH}$, the lower the durability. The measured concentrations are a much more accurate indication. Based on the results in Table 12 the AN-102 glass appears slightly more durable that the LRM glass.

Normalized mass losses are the best indication of the durability of a glass in a PCT. Normalization accounts for the concentration of an element in the glass. The normalized release is a measure of the total mass of glass leached in a PCT based on a specific element in the glass. The specification for ILAW glass is that the normalized mass losses based on $\mathrm{B}, \mathrm{Si}$, and $\mathrm{Na}$, shall each be $<2$ grams of glass per square meter of exposed surface area of glass tested in a $90^{\circ} \mathrm{C} \mathrm{PCT}$ for 7 days [1]. In the PCT, the glass is carefully sieved through standard mesh size sieves so that the surface area of the glass is reproducible from test to test. The exposed surface area of the glass in a PCT has been estimated by assuming that the particles are spherical and that the distribution of particle sizes is Gaussion [11]. The size of the holes in the 100 and 200 mesh sieves are $0.149 \mathrm{~mm}$ and $0.074 \mathrm{~mm}$, respectively. Thus the diameter of the spheres range between these two values with an average value of $1.12 \times 10^{-4} \mathrm{~m}$. Based on these assumptions the exposed surface area has been calculated to be $0.02 \mathrm{~m}^{2}$ per gram of sieved glass.

The normalized mass loss in terms of grams of glass leached is calculated using the following equation

$$
\mathrm{NR}_{\mathrm{i}}=\left(\mathrm{C}_{\mathrm{i}} / \mathrm{C}_{\mathrm{ig}}\right) / 0.02 \times 10^{3}
$$

Where $\mathrm{NR}_{\mathrm{i}}$ is normalized release based on element $\mathrm{i}$, in grams of glass leached per square meter of glass exposed in the PCT. $\mathrm{C}_{\mathrm{i}}$ is the concentration of element $\mathrm{i}$ in ppm in the leachate and $\mathrm{C}_{\mathrm{ig}}$ is the weight percent of element $\mathrm{i}$ in the glass. The PCT procedure prescribes that for every gram of glass, there is exactly $10 \mathrm{~mL}$ of leachate; thus there is $0.02 \mathrm{~m}^{2}$ of glass surface area per $10 \mathrm{~mL}$ of leachate. The factor of 1000 in the denominator results from $\mathrm{C}_{\mathrm{i}}$ being in $\mathrm{ppm}, \mathrm{C}_{\mathrm{ig}}$ in weight percent, and the test condition of $10 \mathrm{~mL}$ per $0.02 \mathrm{~m}^{2}$ of glass.

Table 13 presents the normalized releases calculated from the PCT data and the measured composition of the AN-102 glass (see Table 8). Table 13 presents the averages and standard deviations based on triplicate tests. The normalized releases for all three elements are less than the upper limit of $2 \mathrm{~g}$ glass $/ \mathrm{m}^{2}$ specified in section 2.2.2.17.2 of the Section C, Statement of Work [1]. Thus the glass meets this specification. Table 13 also 
shows similar normalized results for the LRM glass calculated from the PCT data and the measured composition of the LRM glass (see Table 9).

Table 13. Normalized Mass Losses $\left(\mathrm{g}\right.$ glass $\left./ \mathrm{m}^{2}\right)$ Based on $\mathrm{B}$, $\mathrm{Si}$, and $\mathrm{Na}$, For AN-102 Glass in a $90^{\circ} \mathrm{C}$ PCT

\begin{tabular}{|c|c|c|}
\hline & AN-102 Glass & LRM Glass $^{\mathbf{a}}$ \\
\hline Element & Normalized Release $^{\mathbf{a}}$ & Normalized Release $^{\mathbf{a}}$ \\
\hline $\mathrm{B}$ & $0.298 \pm 0.004$ & $0.520 \pm 0.005$ \\
\hline $\mathrm{Si}$ & $0.125 \pm 0.002$ & $0.155 \pm 0.001$ \\
\hline $\mathrm{Na}$ & $0.350 \pm 0.014$ & $0.536 \pm 0.017$ \\
\hline
\end{tabular}

(a) Based on triplicate Product Consistency Tests.

The normalized releases for the AN-102 ILAW glass in Table 13 are very close to those determined for AN-103 ILAW glass and reported earlier [12]. For that glass, the normalized releases for $\mathrm{B}, \mathrm{Si}$, and Na were $0.37 \mathrm{~g} / \mathrm{m}^{2}, 0.17 \mathrm{~g} / \mathrm{m}^{2}$, and $0.40 \mathrm{~g} / \mathrm{m}^{2}$, respectively.

\section{CONCLUSIONS}

The experiments presented in the technical report support use of the technology being proposed by RPP-WTP personnel for pretreatment and immobilization of pretreated Hanford tank 241-AN-102 waste. The AN-102 active waste stream was immobilized into a durable LAW waste glass that meets the specifications set forth in Reference [1]. This demonstration was successful at producing an active AN-102 glass based on formulations provided by VSL. Resulting glass compositions were very similar to the target compositions for the two glasses (active AN-102 and standard LRM) examined.

Analyzed activities from radioactive AN-102 glass for Cs-137, Sr-90 and Tc-99 indicate these radionuclides are present below the average target values in the specification. The transuranic concentrations of the AN-102 glass are well below the contract specification limit for TRU-containing waste. X-ray diffraction and microscopy analyses of active AN-102 glass show this waste form to be amorphous with no evidence for the presence of crystals.

The ASTM standard Product Consistency Test (PCT) performed at $90^{\circ} \mathrm{C}$ on the AN-102 radioactive glass and the Low Activity Reference standard LRM glass showed similar measured releases for the $\mathrm{B}, \mathrm{Si}, \mathrm{Na}$ components. The PCT results indicate that normalized released for $\mathrm{B}, \mathrm{Si}$, and $\mathrm{Na}$ are well below the specification limit of $2 \mathrm{~g}$ glass $/ \mathrm{m}^{2}$. 


\section{CONTROLS AND QUALITY ASSURANCE}

QA and QC programs applied to the testing described in this technical report include SRTC procedures for control of measurement and testing equipment (M\&TE), tracking of radioactive samples, control of laboratory notebooks, and routine ADS QA and QC [16-18]. The QA program applied by SRTC for preparation and analysis of the AN-102 glass sample complies with the requirements of NQA-1. Data sheets for the chemicals used in glass formulation are included in Appendix D of this report.

Analytic standards were required for all analyses performed for this study. Use of these standards is part of routine ADS QA and QC and are part of the procedures in Manual L16.1 for the operating the analytical instrument.

All M\&TE used to perform the evaporation and vitrification experiments was used within the specified calibration period. Calibrations were verified as required for each mass balance instrument. A record of the calibration was routinely maintained in the logbook designated for that piece of equipment.

All personnel who performed steps of the evaporation and vitrification testing were trained on the ITS procedure for operating the evaporation apparatus and furnace. In addition, they were trained on calibrating and operating equipment used in these steps. Training records were maintained for all personnel working on this project.

All laboratory data obtained in the tasks described in this technical report are included as permanent record in Charles L. Crawford's WSRC laboratory notebooks: WSRC-NB98-00196 and WSRC-NB-99-00182. Associated data to these two WSRC laboratory notebooks is also kept as permanent record in the three-ring binders labeled as: LAW Envelope C, Sample AN-102, Vitrification and Product Testing, Charles L.

Crawford. Certain data related to the glass dissolution preparation and the Product Consistency Tests are maintained as permanent record in Daro M. Ferrara's WSRC laboratory notebook: WSRC-NB-2000-00060. 


\section{REFERENCES}

1. TWRS Privatization, Contract No. DE-AC27-96RL13308, Mod. No. M014, Section C: Statement of Work, November 2000. (See http://www.hanford.gov/doe/contracts/de-ac06-

96rl13308/conformed/index.html)

2. Technical and Development Support to TWRS Design, K. A. Johnson and M. E. Johnson, K0104_077_PRC, December 1997.

3. Westinghouse Savannah River Company, "Work for Others Agreement," WFO-96-004, 1996; "Production of a High-Level Waste Glass from Hanford Waste Samples", C. L. Crawford, D. M. Ferrara, B. C. Ha and N. E. Bibler, Proceedings of Spectrum '98, Denver, Colorado, September 1318, 1998, Vol. I, pp. 581-588; "Vitrification of Three Low-Activity Radioactive Waste Streams from Hanford”, D. M. Ferrara, C. L. Crawford, B. C. Ha and N. E. Bibler, Proceedings of Spectrum '98, Denver, Colorado, September 13-18, 1998, Vol. I, pp. 706-713.

4. Westinghouse Savannah River Company, "Work for Others Agreement," WFO-98-003, 1998; RPP-WTP Development Task Specification, Task Specification Number: TS-W375LV-TE00006, "Vitrification of LAW Envelope C Sample AN-102 and Product Testing," S. Arm (BNFL,Inc.) and G. Smith (Battelle), Rev. 0, 12/20/99.

5. "Regulatory Analysis AN-102 Technical Report”, D. M. Ferrara, BNF-003-98-0267, Draft, In Preparation, March 2001.

6. "Strontium - Transuranic Precipitation and Crossflow Filtration of 241-AN-102 Large C", C. Nash, WSRC-TR-2000-00506, SRT-RPP-2001-00006, Formerly BNF-03-98-0317, December 5, 2000.

7. W.D. King, N.M. Hassan, D.J. McCabe, Intermediate-Scale Ion Exchange Removal of Cesium and Technetium from Hanford Tank 241-AN-102, WSRC-TR-2000-00420, SRT-RPP-2000-00024, December 6, 2000.

8. “Glass Former Characterization”, R. Schumacher, BNF-003-98-0188, 11-10-99.

9. (a) "Round-Robin Testing of a Reference Glass for Low-Activity Waste Forms", W. L. Ebert and S. F. Wolfe, ANL-99/22, Argonne National Laboratory, October, 1999; (b) "Dissolution Test for LowActivity Waste Product Acceptance”, W. L. Ebert and S.F. Wolf, Argonne National Laboratory, Proceedings of Spectrum '98, Denver, Colorado, Sept. 13-18, 1998, pp. 724-731.

10. "Characterization of the Low Level Waste Reference Glass (LRM)”, D. Peeler, A. D. Cozzi, D. R. Best, C. J. Coleman and I. A. Reamer, WSRC-TR-99-00095, Rev. 0, March 30, 1999.

11. Annual Book of ASTM Standards, Vol. 12.01. Association of Standards and Test Methods Committee C26, "Standard Test Methods for Determining Chemical Durability of Nuclear Waste Glasses: The Product Consistency Test (PCT),” ASTM C1285-97, (1998), pp. 774-791.

12. “Crucible-Scale Active Vitrification Testing Envelope A, Tank 241-AN-103”, C. L. Crawford, D. M. Ferrara, R. F. Schumacher and N. E. Bibler, BNF-003-98-0237, SRT-RPP-2000-00021, WSRC-TR2000-00322, Rev. 1, 3/01.

13. "Characterization of the Defense Waste Processing Facility (DWPF) Environmental Assessment (EA) Glass Standard Reference Material (U)", C. M. Jantzen, N. E. Bibler, D. C. Beam, C. L. Crawford and M. A. Pickett, WSRC-TR-92-346, Rev. 1, June 1, 1993. 
14. G. B. Mellinger and J. L. Daniel, “Approved Reference and Testing Materials for Use in Nuclear Waste Management Research and Development Programs”, PNL-4955-1, Pacific Northwest Laboratory, December, 1983.

15. C. M. Jantzen, M. A. Pickett, K. G. Brown, T. B. Edwards, and D. C. Beam, "Process/Product Models for the DWPF: Part 1. Predicting the glass Durability from Composition Using a Thermodynamic Energy Hydration Model (THERMO) (U)", Volume 2: Appendix G, Pages G9 - G11, WSRC-TR-93672, Rev. 1 (1995).

16. Westinghouse Savannah River Company, "WSRC 1Q Quality Assurance Manual," Manual 1Q, current revision.

17. Westinghouse Savannah River Company, "WSRC L1 Savannah River Technology Center Procedures Manual," current revision.

18. Westinghouse Savannah River Company, "WSRC L16.1 Analytical Development Section Analytical Operating Procedures Manual," current revision. 
Rev. 0

Formerly BNF-003-98-0271

RPP-WTP Doc. TRPT-W375-00-00028

\section{Appendix A. Glass Recipe for Active AN-102 Glass Product}


Crucible-Scale Active Vitrification Testing

Envelope C, Tank 241-AN-102
WSRC-TR-2000-00371

SRT-RPP-2000-00022

Formerly BNF-003-98-0271

RPP-WTP Doc. TRPT-W375-00-00028

Recipe for glass LAWC21 using High Sulfate Active

May-00 sample

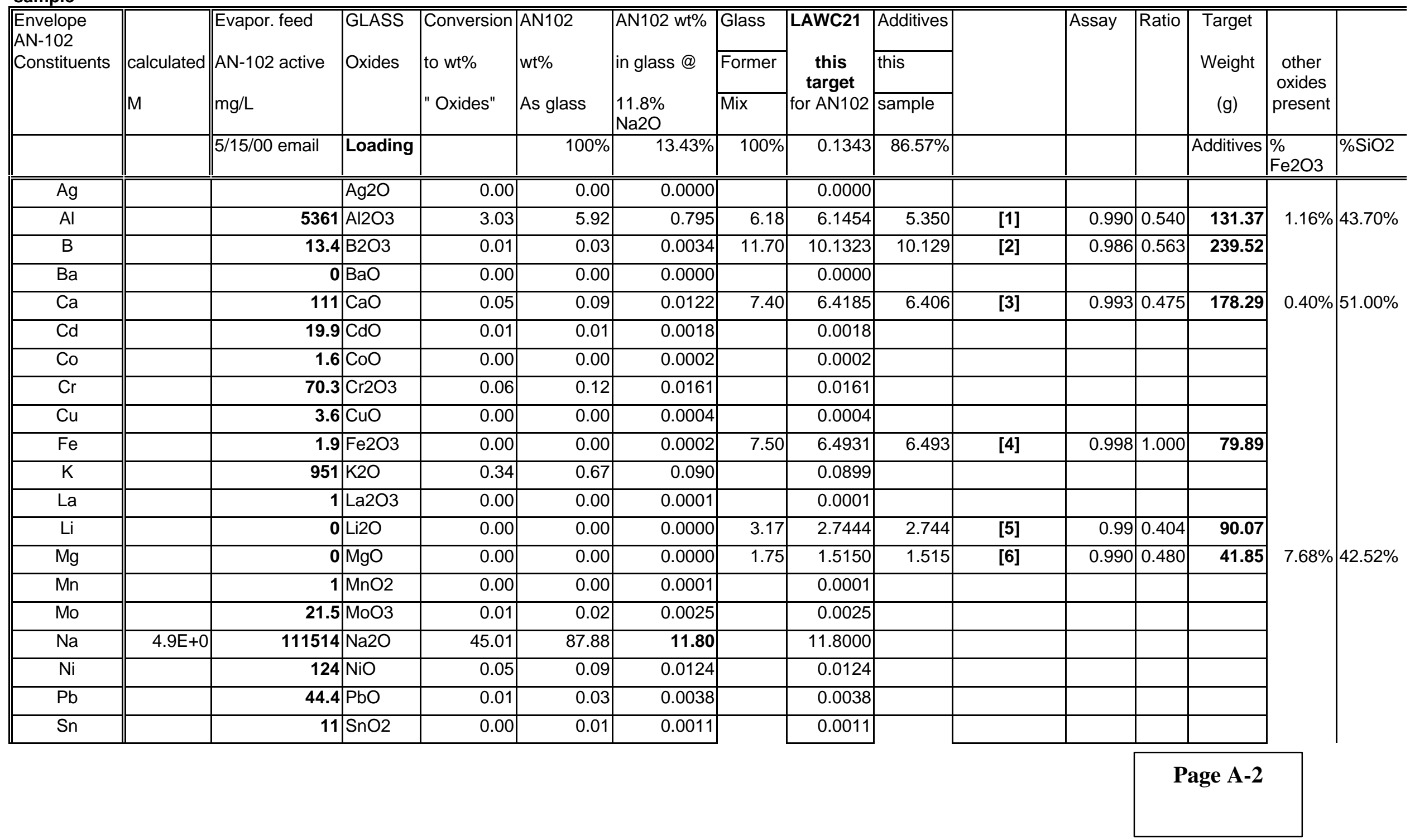


Crucible-Scale Active Vitrification Testing

Envelope C, Tank 241-AN-102

\section{WSRC-TR-2000-00371}

SRT-RPP-2000-00022

Rev. 0

Formerly BNF-003-98-0271

RPP-WTP Doc. TRPT-W375-00-00028

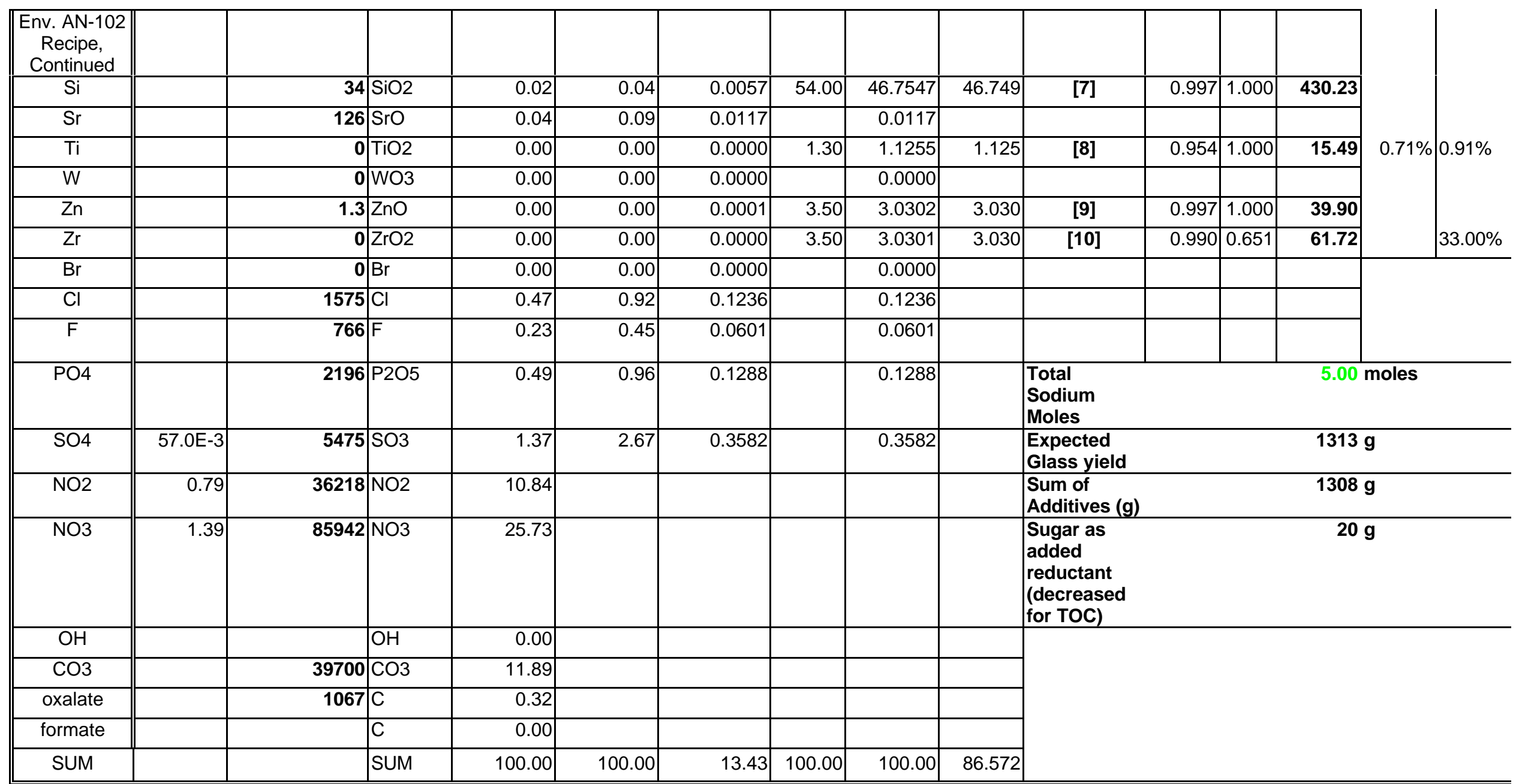

Page A-3 
Crucible-Scale Active Vitrification Testing

Envelope C, Tank 241-AN-102
WSRC-TR-2000-00371

SRT-RPP-2000-00022

Rev. 0

Formerly BNF-003-98-0271

RPP-WTP Doc. TRPT-W375-00-00028

Notes:
\begin{tabular}{|l|l|}
\hline [1] Kyanite (Al2SiO5) 325 Mesh & Kyanite Mining \\
\hline [2] H3BO3 (Technical Granular ) & US Borax \\
\hline $\begin{array}{l}\text { [3] Wollanstonite NYAD 325 Mesh, Calcium } \\
\text { metaSilicate, CaSiO3 }\end{array}$ & NYCO Minerals \\
\hline [4] Fe2O3 (Iron III oxide, -325 Mesh) & Alfa Aesar-Johnson Matthey \\
\hline [5] Li2CO3 (Chemetall Foote Co. Tech.gr. & Cyprus Foote Mineral Co. \\
\hline [6] Olivine (Mg2SiO4) 325 Mesh (\#180) & UNIMIN Corp. \\
\hline [7] SiO2 (Sil-co-Sil 75) & US SILICA \\
\hline [8] TiO2 (Rutile Airfloated) & Chemalloy \\
\hline [9] ZnO (Kadox-920) & Zinc Corp. of America \\
\hline [10] Zircon ZrSiO4 (Flour) Mesh 325 & American Mineral \\
\hline
\end{tabular}

Page A-4 


\section{Appendix B. X-ray Diffraction and Scanning Electron Microscopy Data for $\mathrm{AN}-102$ Glass}

The X-ray diffraction pattern of the radioactive AN-102 glass is presented in Figure B1. No peaks were observed for any crystalline materials indicating that these amorphous glass powders contain no crystalline material above the nominal $0.5 \mathrm{vol} \%$ detection limit of the X-ray diffraction technique. A few small peaks in the XRD spectrum are attributed to the $\mathrm{Cr} / \mathrm{Fe} / \mathrm{Ni}$ oxides. This identification is likely due to trace steel particles in the glass powders that were prepared from grinding the AN-102 active glass in a tungsten blade grinder with steel compartment.

Figure B1. XRD Pattern from Analysis of AN-102 Active Glass

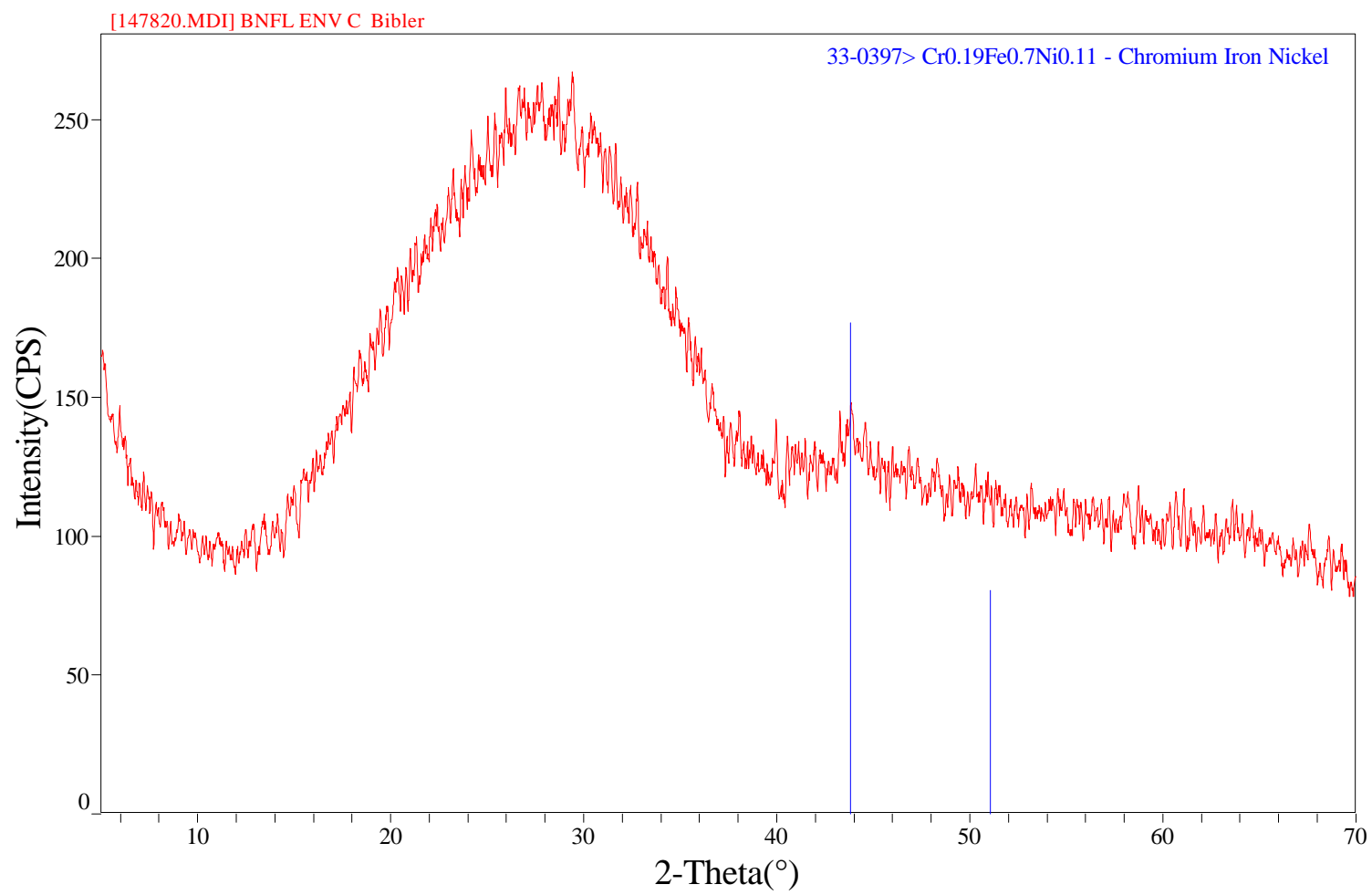

Page B-1 
Table B1 contains summary information on the SEM microscopic images of the powdered glass samples derived from grinding the $\mathrm{AN}-102$ radioactive glass. These glass powders were obtained during preparation of the glass for PCT durability tests using a Techmar tungsten blade grinder with stainless steel grinding compartment. Images obtained from secondary electron and backscattered electron microscopy were obtained at magnifications of 50X and 250X. Generally the SEM technique uses backscattered electrons (BSE), or incident electrons, to indicate potential density differences in the image particles. Use of secondary electron (SE) imaging that involves actual electrons from the matrix material provides topography images of the matrix.

Energy dispersive X-ray analyses were obtained for the matrix particles shown in Figure B7 (SEM Image \#4). The EDAX pattern shown in Figure B5 shows this material to be comprised of the elemental components of the glass matrix, including $\mathrm{Na}, \mathrm{Mg}, \mathrm{Al}, \mathrm{Si}, \mathrm{Zr}$, $\mathrm{K}, \mathrm{Ca}, \mathrm{Ti}, \mathrm{Fe}$ and $\mathrm{Zn}$. SEM image in Figure B6 shows images of the bulk glass matrix particles and relatively smaller particles with apparent different densities than the bulk matrix. These lighter shaded particles were examined with EDAX to produce the pattern shown in Figure B8. This EDAX pattern indicates presence of $\mathrm{Cr}$ and $\mathrm{Ni}$ that is indicative of trace stainless steel particles derived from grinding of the glass. These apparent steel trace contaminants in these analyzed powdered glasses do not interfere with the PCT durability testing since the PCT is conducted in stainless steel containers. Also, is should be noted that separate powdered glass samples obtained from agate ball/mill grinding were analyzed for glass characterization.

Table B1. Summary Information on Microscopy Data

\begin{tabular}{|c|c|c|c|c|}
\hline Figure & SEM Image & Technique & Magnification & EDAX \\
\hline B2 & 2 & BSE & $50-X$ & \\
\hline B3 & 1 & SE & $50-X$ & \\
\hline B4 & 3 & SE & $250-X$ & \\
\hline B5 & 4 & BSE & $250-X$ & \\
\hline B6 & 7 & BSE & $250-X$ & \\
\hline B7 & & BSE & -- & See Fig. B5 \\
\hline B8 & & BSE & -- & See Fig. B6 \\
\hline
\end{tabular}


Rev. 0

Formerly BNF-003-98-0271

RPP-WTP Doc. TRPT-W375-00-00028

Figure B2 showing SEM image 002
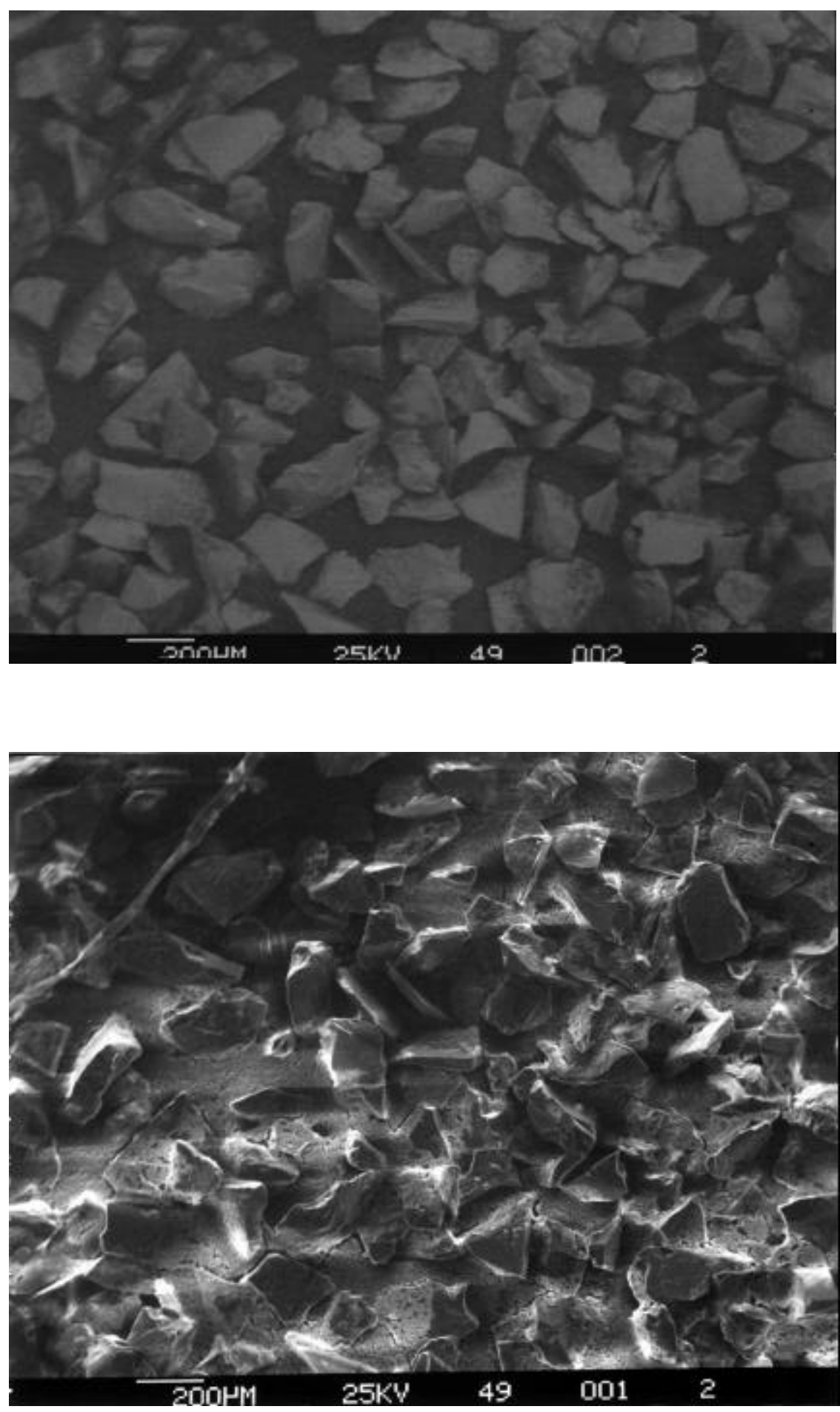

Figure B3 showing SEM image 001. 
Rev. 0

Formerly BNF-003-98-0271

RPP-WTP Doc. TRPT-W375-00-00028

Figure B4 showing SEM image 003
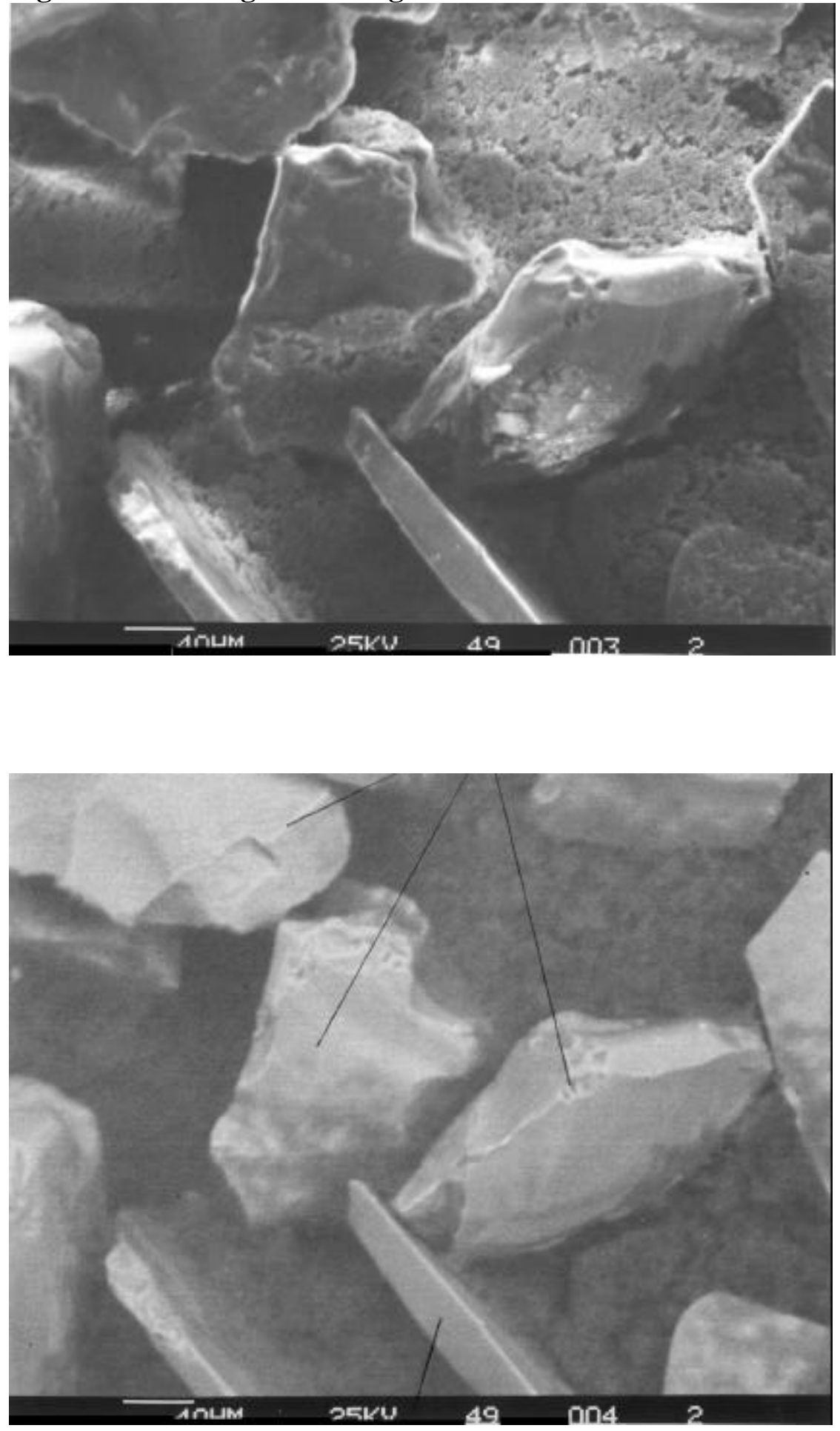

Figure B5 showing SEM image 004. 
Rev. 0

Formerly BNF-003-98-0271

RPP-WTP Doc. TRPT-W375-00-00028

Figure B6 showing SEM image 007

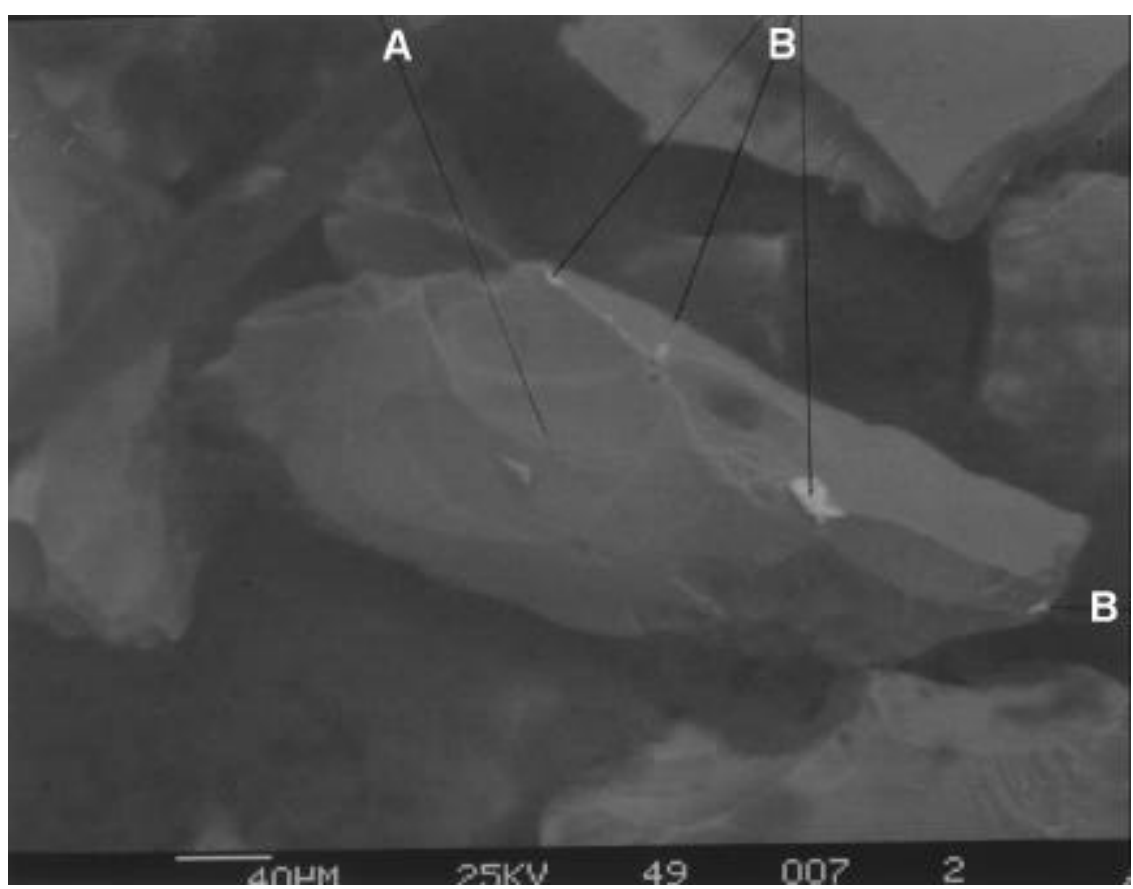

Page B-5 
Rev. 0

Formerly BNF-003-98-0271

RPP-WTP Doc. TRPT-W375-00-00028

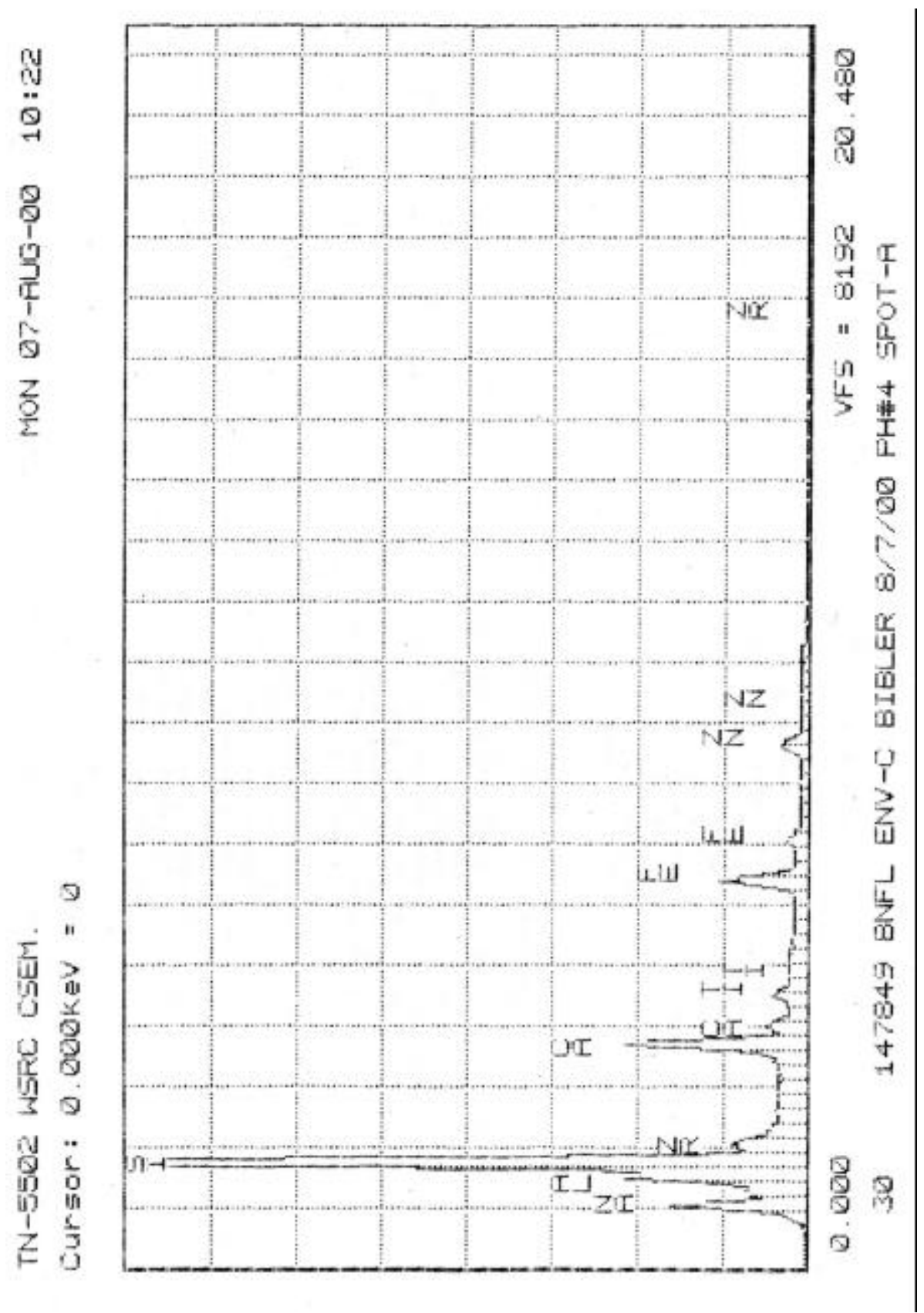

Figure B7: EDAX Pattern from Particles Shown in SEM Image 004 (Figure B5).

Page B-6 
Rev. 0

Formerly BNF-003-98-0271

RPP-WTP Doc. TRPT-W375-00-00028

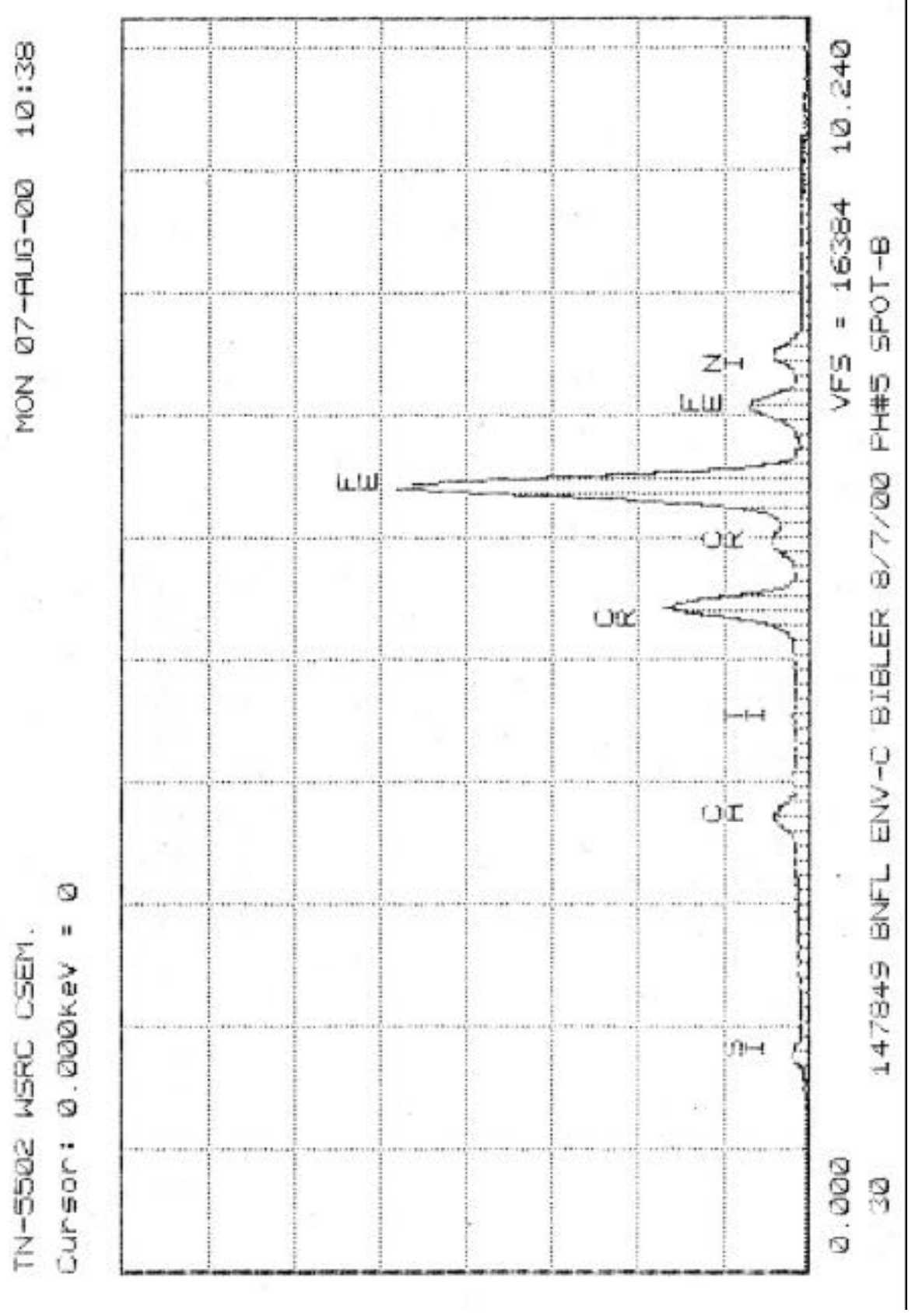

Figure B8. EDAX Pattern from Particles Indicated by 'B', Shown in SEM Image 007 (Figure B6). 
Rev. 0

Formerly BNF-003-98-0271

RPP-WTP Doc. TRPT-W375-00-00028

\section{Appendix C, Page C-1}

Product Consistency Test (PCT) Data 


\section{AN-102 PCT SPREADSHEETS - AN 102 GLASS}

APPENDIX C, PAGE C-2, WSRC-TR-2000-00371, SRT-RPP-2000-00022, Rev. 0, Formerly BNF-003-98-0271, RPP-WTP Doc. TRPT-W375-00-00028 PROCEDURE ASTM-1285-97

DATA AND RESULTS FOR 7 DAY PCT TEST

PROCEDURE CALLS FOR 0.02 M2 PER GRAM OF GLASS AND 10 ML ASTM WATER PER GRAM OF GLASS

TEST NAME 90C PCT WITH BNFL AN 102 GLASS

GLASS. LOW LEVEL RADIOACTIVE AN102 GLASS

DATE IN OVEN

$\begin{array}{lc}\text { DATE IN OVEN } & 7 / 26 / 00 \\ \text { DATE OUT OF OVEN } & 8 / 2 / 00\end{array}$
$\begin{array}{lc}\text { DATE IN OVEN } & 7 / 26 / 00 \\ \text { DATE OUT OF OVEN } & 8 / 2 / 00\end{array}$

LEACHATE DILUTION FACTORS: 10 ML SPL AND 0.10ML CONC HNO3 DF $=10.1 / 10=1.01$ $\begin{array}{ll}\text { TIME IN OVEN } & 10: 19 \\ \text { TIME OUT OF OVEN } & 10: 19\end{array}$ HNO3/4 ML ASTM H2O $\mathrm{H}=\quad 6.57$ RAW EXPERIMENTAL DATA SAMPLE WEIGHTS NAME

$\begin{array}{cc} & \text { WEIGHTS } \\ \text { EMPTY } & \text { W/GLASS } \\ 119.499 & \text { N.A. } \\ 119.742 & \text { N.A. } \\ 120.948 & \text { N.A. }\end{array}$

GLASS
N.A.
N.A.
N.A.

$\begin{array}{ccccc}\text { WEIGHT } & \text { INITIAL } & \text { FINAL } & & \\ \text { WEIGHT } & \text { WEIGHT } & \text { INIT. } & \text { WATER } \\ \text { W/H2O } & \text { IN PCT } & \text { IN PCT } & \text { VOL.(ML) } & \text { LOSS } \\ 136.027 & 337.558 & 337.569 & 16.000 & -0.011 \\ 136.259 & 338.582 & 338.596 & 16.000 & -0.014 \\ 137.478 & 338.984 & 338.982 & 16.000 & 0.002\end{array}$

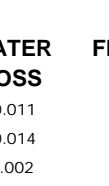

$\begin{array}{ccccccc}\text { FINAL } & \text { ANALYTICAL } & \text { RESULTS } & \text { (ppm) FOR ACIDIFIED LEACHATES. } \\ \text { pH } & \text { NUMBER } & \text { B } & \text { Si } & \text { Na } & \text { Li } & \text { Al } \\ 6.66 & 3-147788 & 0.031 & 0.059 & 0.602 & 0.016 & <016 \\ 6.94 & 3-147793 & 0.033 & 0.037 & 0.198 & 0.011 & <016 \\ 6.39 & 3-147798 & 0.023 & 0.043 & 0.155 & 0.008 & <016\end{array}$

BLANK AVERAGE

SAMPLES

P431 BNFL-AN 102-1

P432 BNFL-AN 102-2

119.734
120.566

120.566

$\begin{array}{ll}\text { N.A. } & \text { N.A. } \\ \text { N.A. } & \text { N.A. } \\ \text { N.A. } & \text { N.A. }\end{array}$

$\begin{array}{lllll}\text { N.A. } & 338.57 & 338.565 & 338.569 & \text { NA } \\ \text { N.A. } & 339.481 & 339.474 & 339.477 & \text { NA }\end{array}$

0.029

0.046

$0.318 \quad 0.012$

P433 BNFL-AN 102-3

$\begin{array}{lll}338.855 & 338.847 & 339.477 \\ & & 338.852\end{array}$

$\begin{array}{ll}0.004 & 10.5\end{array}-347789$

$\begin{array}{llll}\text { NA } & -0.003 & 10.6 & 3-147794 \\ \text { NA } & -0.005 & 10.6 & 3-14779\end{array}$

$\begin{array}{lllll}5.763 & 17.063 & 19.356 & 2.777 & 0.690 \\ 5.838 & 17.098 & 18.967 & 2.790 & 0.644\end{array}$

$\begin{array}{lllll}5.674 & 16.718 & 17.935 & 2.596 & 0.646\end{array}$

CALCULATED RESULTS: WATER LOSS, PH VALUES, AND FILTERED LEACHATE CONCENTRATIONS CORRECTED FOR BLANKS

\section{SAMPLE}

P431 BNFL -AN 102-1

P432 BNFL-AN 102-2

P433 BNFL-AN 102-3

\begin{tabular}{cccccc} 
GLASS & INIT. & FINAL & $\%$ & \multicolumn{2}{c}{ pH VALUES } \\
WEIGHT & VOL.(ML) & VOL.(ML) & LOSS & INITIAL & FINAL \\
1.686 & 16.860 & 16.871 & -0.024 & 6.6 & 10.5 \\
1.639 & 16.390 & 16.404 & -0.018 & 6.6 & 10.6 \\
1.632 & 16.320 & 16.318 & -0.031 & 6.6 & 10.6
\end{tabular}

AVERAGE

STANDARD DEVIATION

REL. STD. DEVIATION (\%)

NORMALIZED CALCULATIONS

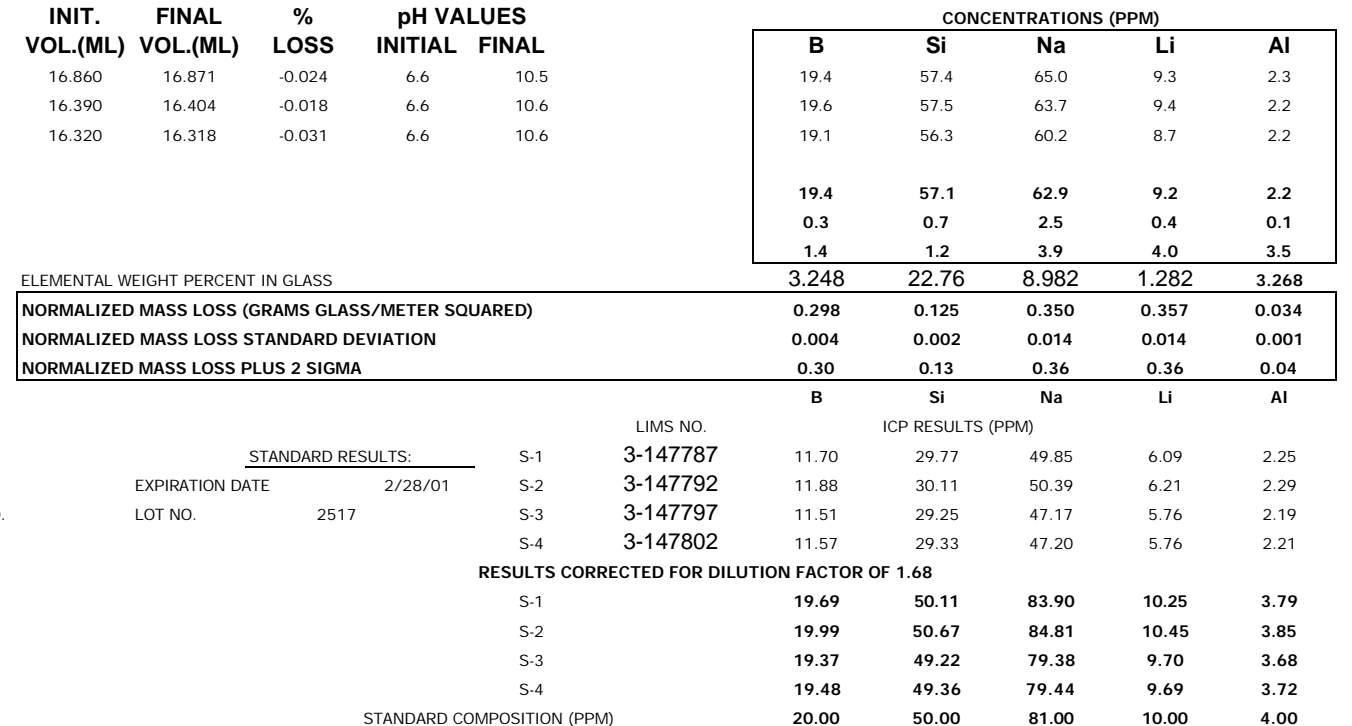

RESEARCHER: NED BIBLER

PHMETER SER.H=81201792

OVEN SER.\#OV3-30228
BUFFERED TO PH 7AND 10 


\section{AN-102 PCT SPREADSHEETS - LRM GLASS}

APPENDIX C, PAGE C-3, WSRC-TR-2000-00371, SRT-RPP-2000-00022, Rev, 0, Formerly BNF-003-98-0271, RPP-WTP Doc. TRPT-W375-00-00028 PROCEDURE ASTM-1285-97

DATA AND RESULTS FOR 7 DAY PCT TEST

TEST NAME 90C PCT WITH BNFL ENVELOPE C GLASS

\section{GLASS. LRM GLASS}

DATE IN OVEN

$\begin{array}{lc}\text { DATE IN OVEN } & 7 / 26 / 00 \\ \text { DATE OUT OF OVEN } & 8 / 2 / 00\end{array}$

TIME IN OVEN
TIME OUT OF O

INITIAL pH = $\quad 6.57$

RAW EXPERIMENTAL DATA

SAMPLE WEIGHTS

NAME EMPTY W/GLASS

P452 Blank-C-1

P453 Blank -C-2

P454 Blank -C-3

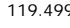

W/GLASS

119.499

$119.742 \quad$ N.A.

$120.948 \quad$ N.A.

BLANK AVERAGE

SAMPLES

P434 LRM -C -

P435 LRM-C. 2

P436 LRM-C-3

122.721
121.929

1.655
1.656

139.273
138.498

138.856
INITIAL FINAL

WEIGHT WEIGHT WEIGHT INIT. WATER

W/H2O IN PCT IN PCT VOL.(ML) LOSS

136.259
- A. $\quad 137.478$

$137.478=338.582$

ANALYTICAL DETECTION LIMITS

\section{CALCULATED RESULTS: WATER LOSS, pH VALUES, AND FILTERED LEACHATE CONCENTRATIONS CORRECTED FOR BLANKS}

$\begin{array}{lcccccc}\text { SAMPLE } & \text { GLASS } & \text { INIT. } & \text { FINAL } & \% & \text { PH VALUES } \\ \text { NAME } & \text { WEIGHT } & \text { VoL.(ML) } & \text { VOL.(ML) } & \text { LosS } & \text { INITIAL } & \text { FINAL } \\ \text { P434 LRM -C-1 } & \mathbf{1 . 6 5 5} & 16.552 & 16.556 & -0.024 & \mathbf{6 . 9 7} & 10.76 \\ \text { P435 LRM-C-2 } & \mathbf{1 . 6 5 2} & 16.569 & 16.575 & -0.036 & \mathbf{6 . 9 7} & 10.80 \\ \text { P436 LRM-C-3 } & \mathbf{1 . 6 5 5} & 16.587 & 16.595 & -0.048 & \mathbf{6 . 9 7} & 10.86\end{array}$

LEACHATE DILUTION FACTORS:

$\mathrm{DF}=10.1 / 10=1.01$

ARM AND STANDARDS : $6 \mathrm{ML}$ SPL/0.1 ML CONC HNO3/4 ML ASTM H2O DF $=1.683$ ENV C AND LRM: 3ML SPL/7ML HOH/0.1ML CONC HNO3

$\mathrm{DF}=3.367$

\section{AVERAGE}

STANDARD DEVIATION

REL. STD. DEVIATION (\%)

NORMALIZED CALCULATIONS:

QUALITY ASSURANCE INFORMATION:

\section{$\angle A B \#=B-111$}

PH METER SER.\#=81201792

BALANCE SER.\#=1119180391

OVEN SER.\#OV3-30228

NORMALIZED MASS LOS

NORMALIZED MASS LOSS STANDARD DEVIATION

NORMALIZED MASS LOSS PLUS 2 SIGMA

SRTC

ANALYTICAL RESULTS (ppm) FOR ACIDIFIED LEACHATES.

$\begin{array}{llllll}\text { NUMBER } & \mathbf{B} & \mathrm{Si} & \mathrm{Na} & \mathbf{L i} & \mathrm{Al}\end{array}$

$$
\text { 3-147788 }
$$

3-147793

0.031
0.033

$\mathrm{Si}$
0.059

$\begin{array}{ccc}\mathrm{Na} & \mathbf{L i} & \mathbf{A l} \\ 0.602 & 0.016 & <016\end{array}$

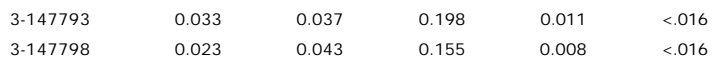

FILTER SIZE: 45 MICRON

STANDARD RESULTS:
EXPIRATION DATE
$2 / 28 / 01$

EXPIRATION
LOT NO. 2517

(2)

\section{FINAL}

$\begin{array}{llll}0.029 & 0.046 & 0.318 & 0.012\end{array}$

3-147790

$3-147795$
$3-147800$

$\begin{array}{lll}49.484 & 0.028 & 4.484\end{array}$

$\begin{array}{lllll}7.575 & 23.783 & 49.484 & 0.028 & 4.484 \\ 7.562 & 23.576 & 46.628 & 0.027 & 4.410 \\ & 24.027 & 47.151 & 0.025 & 4.502\end{array}$

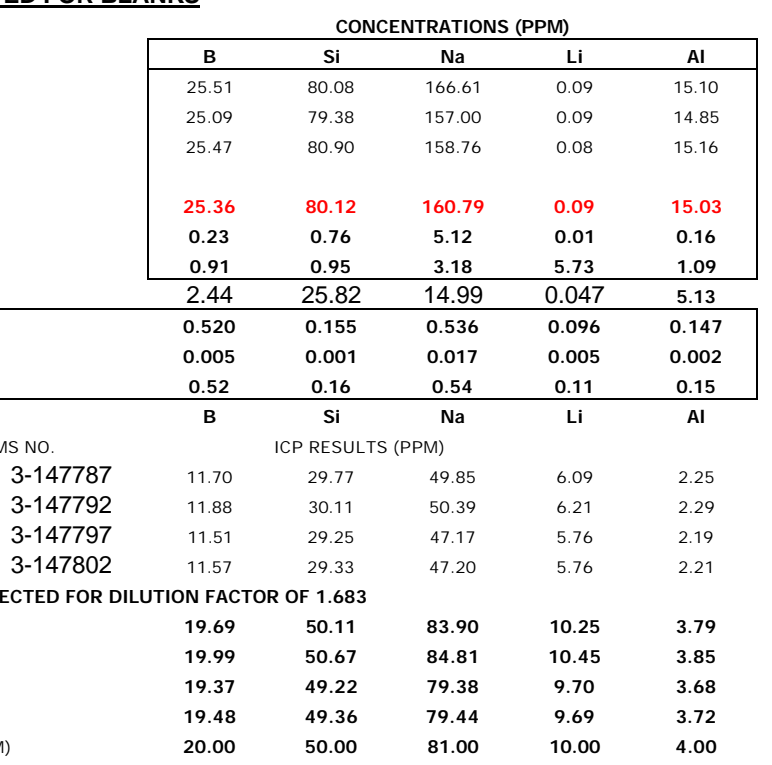




\section{AN-102 PCT SPREADSHEETS - ARM GLASS}

APPENDIX C, PAGE C-4, WSRC-TR-2000-00371, SRT-RPP-2000-00022, Rev. 0, Formerly BNF-003-98-0271, RPP-WTP Doc. TRPT-W375-00-00028 PROCEDURE ASTM-1285-97

DATA AND RESULTS FOR 7 DAY PCT TEST

TEST NAME 90C PCT WITH BNFL ENVELOPE C GLASS

\section{GLASS. ARM GLASS}

DATE IN OVEN

\section{TIME IN OVEN
TIME OUT OF OVE}

INITIAL pH $=\quad 6.57$

INITIAL FINAL

RAW EXPERIMENTAL DATA SAMPLE$$
\text { NAME }
$$

P452 Blank-C-1

P453 Blank -C-2

P454 Blank -C-3

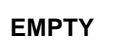

WEIGHTS

EMPTY W/GLASS GLASS

119.499

119.742

N.A.

W/H2O INPCT INPCT VOL (ML) LOSS

$136027-337.558-337.569-16000$

136.027

136.259

337.558

337.569
338.596

$338.984-338.982-16.000 \quad-0.014$

WEIGHT WEIGHT WEIGHT INIT WATER FINAL ANAL

BLANK AVERAGE

SAMPLES

P437 ARM-C-1

P438 ARM $-\mathrm{C}-2$

137.478

119.748

121.036
121.402

$\begin{array}{ll}1.659 & 137.631 \\ 1.658 & 137.989\end{array}$

137.989
138.364

338.799

$138.364 \quad 339.524$

$\begin{array}{lll}338.807 & 16.595 & -0.008 \\ 339.490 & 16.587 & -0.004 \\ 339.532 & 16.607 & -0.008\end{array}$

LEACHATE DILUTION FACTORS:

DF $=10.1 / 10=1.01$

ARM AND STANDARDS : $6 \mathrm{ML}$ SPL/0.1 ML CONC HNO3/4 ML ASTM H2O DF $=1.683$ ENV A AND LRM: 3ML SPL/7ML HOH/0.1ML CONC HNO3

$\mathrm{DF}=3.367$

CALCULATED RESULTS: PH VALUES AND FILTERED LEACHATE CONCENTRATIONS CORRECTED FOR BLANKS 10.26

\begin{tabular}{|c|c|c|c|c|c|}
\hline \multirow{3}{*}{$\begin{array}{c}\text { SRTC } \\
\text { ANALYTICAL } \\
\text { NUMBER }\end{array}$} & \multirow{2}{*}{\multicolumn{5}{|c|}{ RESULTS (ppm) FOR ACIDIFIED LEACHATES. }} \\
\hline & & & & & \\
\hline & B & Si & $\mathrm{Na}$ & $\mathbf{L i}$ & Al \\
\hline 3-147788 & 0.031 & 0.059 & 0.602 & 0.016 & $<016$ \\
\hline 3-147793 & 0.033 & 0.037 & 0.198 & 0.011 & $<016$ \\
\hline 3-147798 & 0.023 & 0.043 & 0.155 & 0.008 & $<016$ \\
\hline & 0.029 & 0.046 & 0.318 & 0.012 & \\
\hline 3-147791 & 10.836 & 39.036 & 23.834 & 9.098 & 3.091 \\
\hline 3-147796 & 11.106 & 39.002 & 23.087 & 8.707 & 2.936 \\
\hline 3-147801 & 10.768 & 38.779 & 22.612 & 8.540 & 3.001 \\
\hline
\end{tabular}

$\begin{array}{lcccccc}\text { SAMPLE } & \text { GLASS } & \text { INIT. } & \text { FINAL } & \% & \text { PH VALUES } & \\ \text { NAME } & \text { WEIGHT } & \text { VOL.(ML) } & \text { VOL.(ML) } & \text { LOSS } & \text { INITIAL } & \text { FINAL } \\ \text { P437 ARM-C-1 } & \mathbf{1 . 6 5 8} & 16.595 & 16.603 & -0.0663 & \mathbf{6 . 5 7} & 10.24 \\ \text { P438 ARM -C-2 } & \mathbf{1 . 6 5 4} & 16.587 & 16.591 & -0.0844 & \mathbf{6 . 5 7} & 10.23 \\ \text { P439 ARM -C-3 } & \mathbf{1 . 6 5 4} & 16.607 & 16.615 & 0.0120 & \mathbf{6 . 5 7} & 10.26\end{array}$

\section{AVERAGE}

STANDARD DEVIATION

REL. STD. DEVIATION (\%)

NORMALIZED CALCULATIONS

ELEMENTAL WEIGHT PERCENT IN GLASS

NORMALIZED MASS LOSS (GRAMS GLASS/ LITER/

NORMALIZED MASS LOSS STANDARD DEV
NORMALIZED MASS LOSS PLUS 2 SIGMA

QUALITY ASSURANCE INFORMATION:

LAB\#=B-111

PH METER SER.\#=81201792

BALANCE SER.\#=1119180391

OVEN SER.\#OV3-30228

BUFFERED TO PH TAND 10

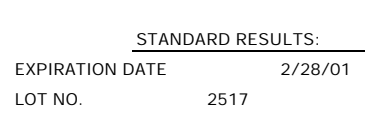

LUES FOR CONCENTRATIONS IN ARM GLASS PCT

$\begin{array}{ccc}\mathbf{S i} & \mathbf{N a} & \mathbf{L i} \\ 73.4 & 43.6 & 16.3 \\ 49.0 & 28.9 & 10.8\end{array}$

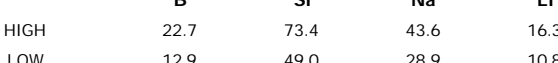

\begin{tabular}{|c|c|c|c|c|}
\hline & \multicolumn{4}{|c|}{ CONCENTRATIONS } \\
\hline B & $\mathbf{S i}$ & $\mathrm{Na}$ & $\mathbf{L i}$ & Al \\
\hline 18.2 & 65.7 & 39.8 & 15.3 & 5.2 \\
\hline 18.7 & 65.6 & 38.5 & 14.6 & 4.9 \\
\hline 18.1 & 65.2 & 37.7 & 14.4 & 5.1 \\
\hline 18.3 & 65.5 & 38.7 & 14.8 & 5.1 \\
\hline 0.30 & 0.23 & 1.04 & 0.48 & 0.13 \\
\hline 1.64 & 0.36 & 2.68 & 3.26 & 2.59 \\
\hline
\end{tabular}

S-1
S-2
S-3
S-4
STANDARD COMPOSITION (PPM)

ADS. NO.
3-147787
$3-147792$
$3-147797$
$3-147802$

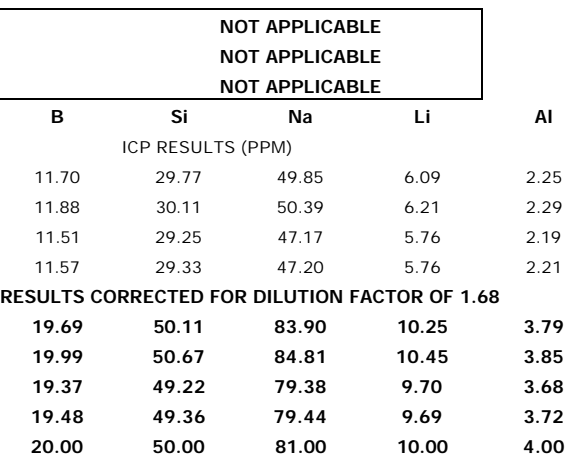


Rev. 0

Formerly BNF-003-98-0271

RPP-WTP Doc. TRPT-W375-00-00028

\author{
Appendix D \\ Data Sheets for Glass Forming Minerals
}

Page D-1 
Rev. 0

Formerly BNF-003-98-0271

RPP-WTP Doc. TRPT-W375-00-00028

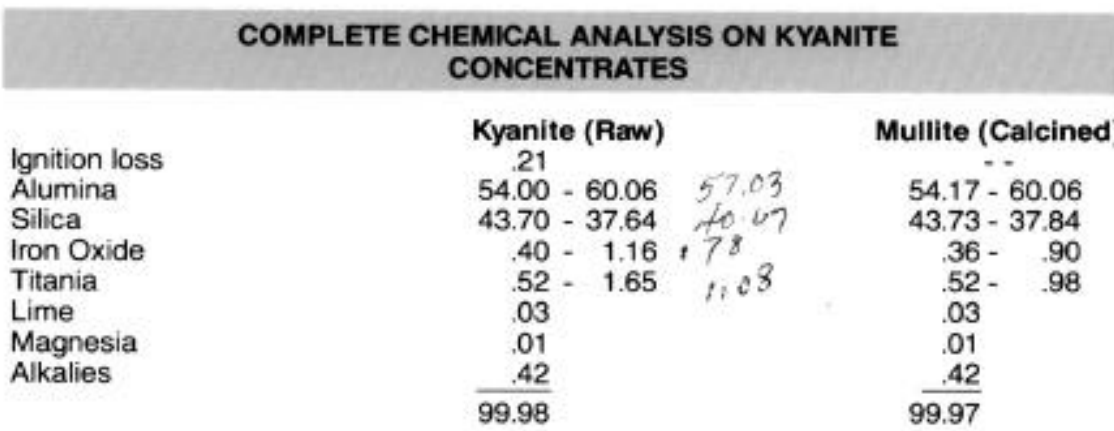

Composition - Raw Kyanite $3 \mathrm{AL}_{2} \mathrm{O}_{3}-3 \mathrm{SiO}_{2}$

Calcined Kyanite (Mulite) $3 \mathrm{AL}_{2} \mathrm{O}_{3}-2 \mathrm{SiO}_{2}$

Physical Properties - a. Streak - uncolored

b. Hardness - 4 to 7 Mohr's Scale

c. Specific Gravity Kyanite 3.5 to 3.7

Mullite 2.9 to 3.1

d. Lustre - vitreous to pearly

e. Color - dark grey to sandy

f. Particle shape - bladed (elongated)

Pyrometric Cone Equivalent - Cone 36 to 37

The Calcined Kyanite (Mullite) has been completely converted at a temperature of 3000 deg. F, by Kyanite Mining Corp.

$$
\begin{aligned}
& \text { Mines - Dillwyn, Virginia (East Ridge Mountain) } \\
& \text { Dillwyn, Virginia (Willis Mountain) } \\
& \text { Kyanite Grinding Plants - East Ridge } \\
& \text { Gieseke } \\
& \text { Pamplin } \\
& \text { Mullite Production \& Grinding Plants - Dillwyn } \\
& \text { Cullen } \\
& \text { East Ridge }
\end{aligned}
$$

\section{TYPICAL SCREEN ANALYSES ON VIRGINIA KYANITE \& MULLITE}

\section{KYANITE PRODUCTS}

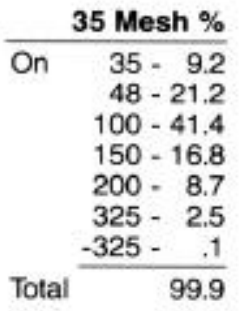
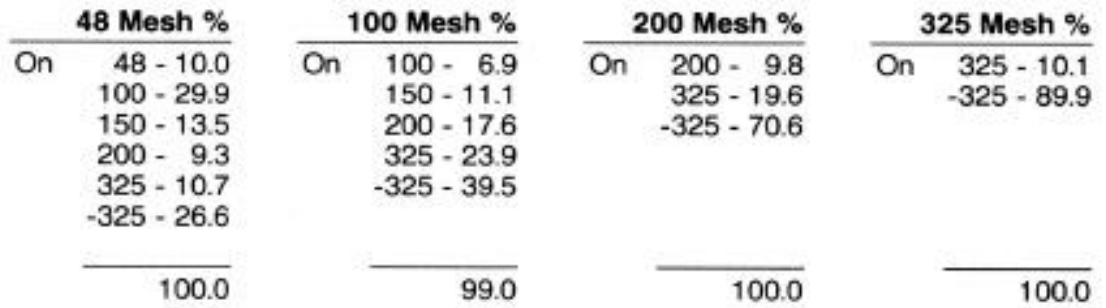

\section{MULLITE (Calcined Kyanite) PRODUCTS}

35 Mesh \%

On \begin{tabular}{r}
$35-16.9$ \\
$48-21.6$ \\
$100-38.1$ \\
$150-13.2$ \\
$200-6.9$ \\
$325-2.6$ \\
Total $\quad .6$ \\
\cline { 2 - 2 }$-325-99.9$
\end{tabular}

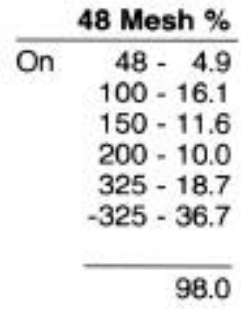

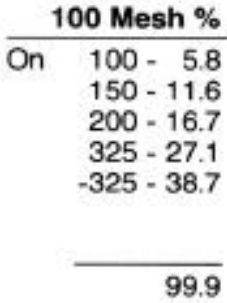
200 Mesh \%
$325-18.1$
$-325-72.0$

325 Mesh \%

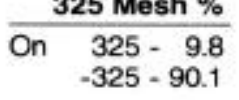

$-325-90.1$

$-11.6$

$200-16.7$

$325-27.1$

99.9 


\section{MULE TEAM"}

\section{Boric Acid}

\section{Technical Granular}

Orthoboric Acid

$\mathrm{H}_{3} \mathrm{BO}_{3}$

CAS No. 10043-35-3

\section{Product Specification} B-0310-U

May 1,1998

Boric Acid Technical Granular is a free-flowing, white, crystalline product manufactured in the USA by U.S. Borax Inc.

\section{Chemical specification}

\begin{tabular}{lcc}
\hline & Guarantee \\
\hline $\mathrm{B}_{2} \mathrm{O}_{3} \%$ & $56.25-56.80$ & 56.52 \\
Equivalent $\mathrm{H}_{3} \mathrm{BO}_{3} \%$ & $99.9-100.9$ & \\
$\mathrm{SO}_{4}$ ppm & $\leq 350$ \\
$\mathrm{Cl}$ ppm & $\leq 18$ \\
$\mathrm{Fe} \mathrm{ppm}$ & $\leq 6$ \\
\hline
\end{tabular}

\section{Sieve specification}

\begin{tabular}{lc}
\hline $\begin{array}{l}\text { U.S. Standard } \\
\text { Sieve No. }\end{array}$ & $\begin{array}{c}\text { \% Retained } \\
\text { Guarantee }\end{array}$ \\
\hline 20 & $\leq 2.0$ \\
\hline
\end{tabular}

Note:

All data in the above specifications are determined by U.S. Borax analytical methods.

\section{Packaging}

Boric Acid Technical Granular is available in bulk, in $2500 \mathrm{lb}$.

IBCs and in $50 \mathrm{lb}$. multiwall paper sacks.

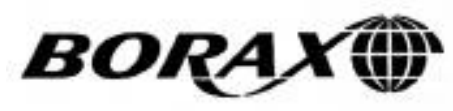

Issued by:

U.S. Borax Inc.

26877 Tourney Road

Valencia, CA 91355-1847

USA 
Wolastonite $=$ Calcium Metasilicate, $\mathrm{CaSiO}_{3}$

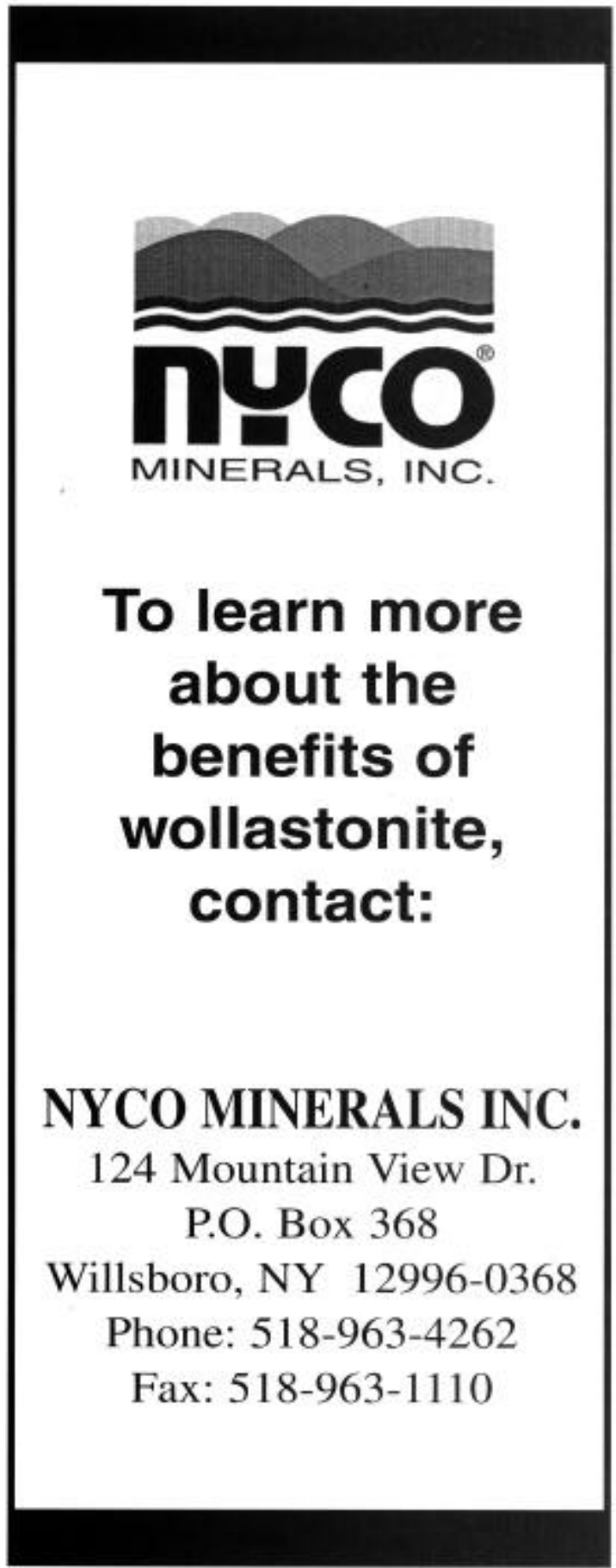

\section{Wollastonite}

\section{Key Benefits and Properties}

Production Benefits of Using Wollastonite in Sanitaryware*

Shrinkage maintained to comply with mold standards Reduced vitrification temperature

Increased impact resistance

Increased drying temperature

Reduced drying time

Reduced HF emissions

Improved fired strength

*wollastonite with a very high aspect ratio

Typical Physical and Chemical Properties of Wollastonite

Appearance White

Particle Shape

Molecular Weight Acicular

Specific Gravity

Refractive Index

$\mathrm{pH}\langle 10 \%$ slurry $)$

Water Solubility (g/100cc)

Density (lbs./solid gallons)

Mohs Hardness

Coefficient of Expansion $\left(\mathrm{mm} / \mathrm{mrn} /{ }^{\circ} \mathrm{C}\right)$

Chemical Composition

$\mathrm{CaO} \quad 47,5$

$\mathrm{SiO}_{2}$

$\mathrm{Fe}_{2} \mathrm{O}_{3}$

$\mathrm{TH}_{2}$ 
Rev. 0

Formerly BNF-003-98-0271

RPP-WTP Doc. TRPT-W375-00-00028

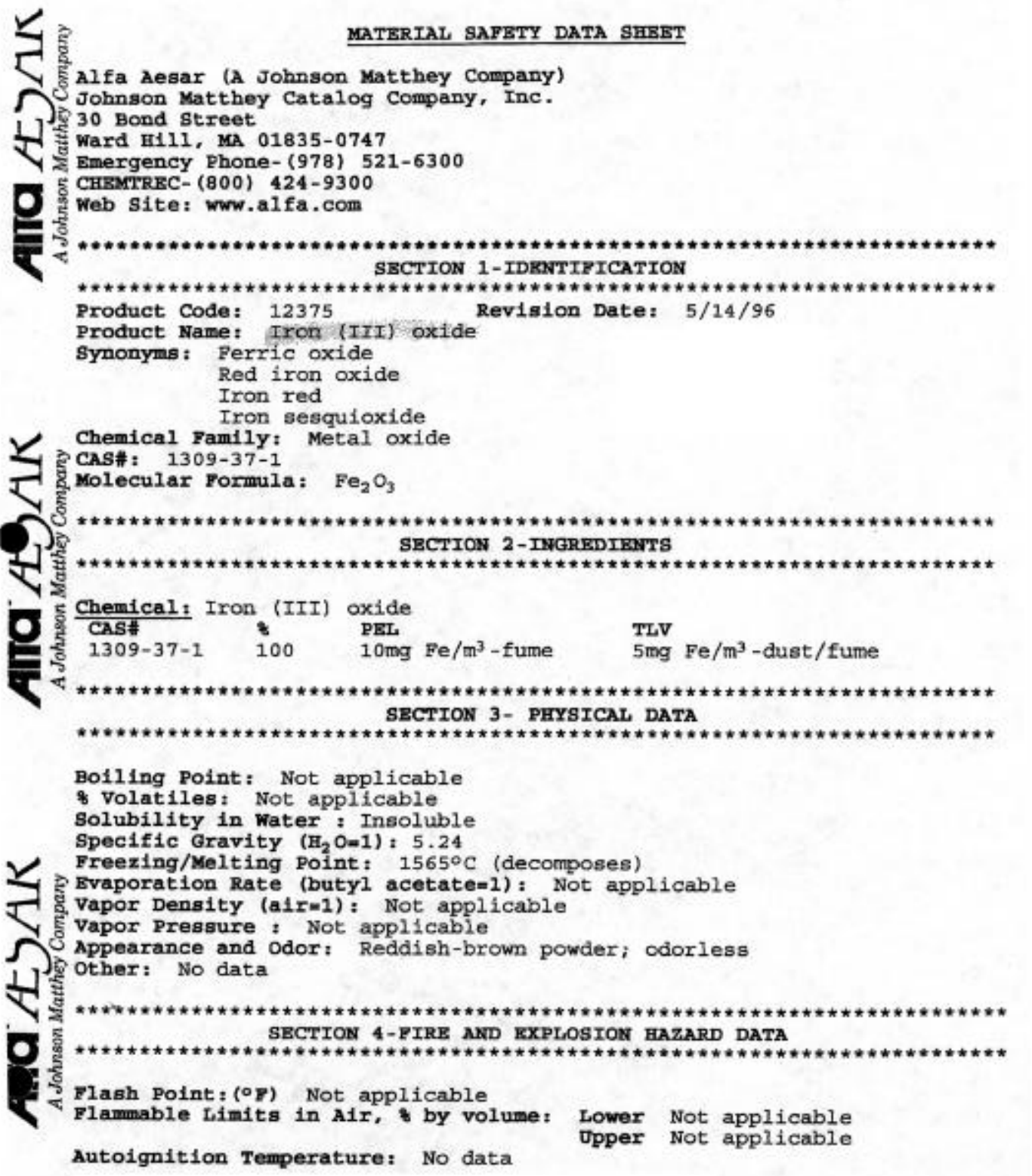

\section{Page D-5}


Rev. 0

Formerly BNF-003-98-0271

RPP-WTP Doc. TRPT-W375-00-00028

\section{TECHNICAL DATA}

CHEMICAL ANALYSIS

Mean Values. These Do Not Represent A Specification.

$\begin{array}{llr}\begin{array}{l}\text { Magneslum Oxide } \\ \text { Silicon Dioxide }\end{array} & (\mathrm{MgO}) & \begin{array}{c}\text { Mean Percent } \\ \text { by Weight }\end{array} \\ \text { Iron Oxide } & \left(\mathrm{SiO}_{2}\right) & 48.01 \\ \text { Calclum Oxide } & \left(\mathrm{Fe}_{2} \mathrm{O}_{3}\right) & 42.52 \\ \text { Chromlum Oxide } & \left(\mathrm{CeO}^{2}\right) & 7.68 \\ \text { Aluminum Oxide } & \left(\mathrm{Cr}_{2} \mathrm{O}_{3}\right) & 0.02 \\ \text { Potasslum Oxide } & \left(\mathrm{A}_{2} \mathrm{O}\right) & 0.13 \\ \text { Sodium Oxide } & \left(\mathrm{Na}_{2} \mathrm{O}\right) & 0.19 \\ \text { Nickel Oxide } & (\mathrm{NiO}) & .01 \\ \text { Loss on lgnition } & (\mathrm{LOI}) & .02 \\ & & .37 \\ & & 1.05\end{array}$

\section{ORDERING INFORMATION}

Shipping Point:

Availability:
HAMILTON, WA

BULK, 50 LB., 100 LB., ANO BULK BAGS TRUCK AND RAIL

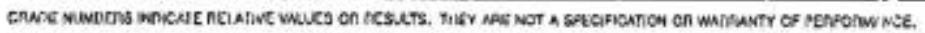

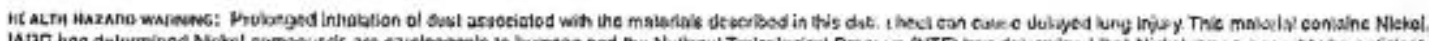

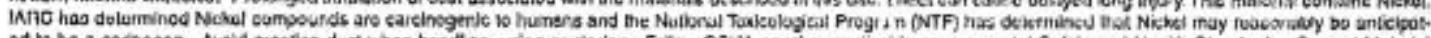

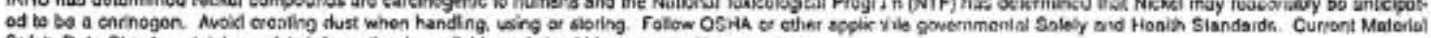

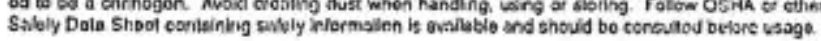

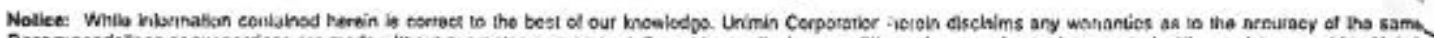

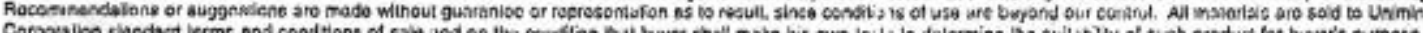

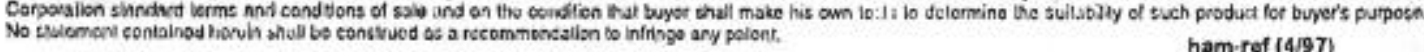
ham-rof (4/97) 
Rev. 0

Formerly BNF-003-98-0271

RPP-WTP Doc. TRPT-W375-00-00028

\section{SIL-CO-SIL, GROUND SILICA FROM U.S. SILICA COMPANY}

\begin{tabular}{|c|c|c|c|c|c|c|c|c|c|c|c|}
\hline \multirow{2}{*}{$\begin{array}{l}\text { Now Name } \\
\text { Old Name }\end{array}$} & & \multicolumn{4}{|c|}{75} & \multicolumn{3}{|c|}{63} & \multicolumn{3}{|c|}{53} \\
\hline & & 200 Mesin & 200 Mean 12 & 200 Mean & 200 Mesn & & & 270 Mesa & 270 Mesn & & \\
\hline Mine & & $\begin{array}{c}\text { Pacine. } \\
\text { MO }\end{array}$ & $\begin{array}{c}\text { Colimmbia. } \\
\text { sc }\end{array}$ & $\begin{array}{c}\text { Mili Creet. } \\
\text { or }\end{array}$ & $\begin{array}{l}\text { Fertaiev } \\
\text { sorngr. mivi }\end{array}$ & & & $\begin{array}{l}\text { Berteiey } \\
\text { Sorings. WV }\end{array}$ & $\begin{array}{c}\text { Mali Cieen, } \\
\text { Or }\end{array}$ & + & \\
\hline \multicolumn{12}{|l|}{ Seve Anaivs } \\
\hline Cum. $\%+100$ Mesh & & Trace & tioce & Troce & 0.1 & & & 0.1 & Troce & & \\
\hline Cum. $\%+200$ Mein & & 10 & 15 & 15 & 0.7 & & & 0.3 & 0.5 & & \\
\hline Cum. $\%+325$ Mash & & 120 & 130 & 13.0 & 12.0 & & & 80 & 70 & & \\
\hline \multicolumn{12}{|l|}{ Particle Size } \\
\hline Medien (Micronst & & 170 & 10.0 & 15.0 & 100 & & & 15.0 & 12.0 & & \\
\hline Average (Micrenst & & 0.0 & 0.0 & 0.0 & 6.0 & & & 5.5 & 5.5 & & \\
\hline Specitic Surtoce Avea. icmifat & & 3800 & 3800 & 3800 & 3800 & & & 4200 & $\triangle 200$ & & \\
\hline Oll Absorption, flbs: 100 lbst & : & 20.5 & 220 & 200 & 24.0 & ' & & 25.0 & 21.0 & & \\
\hline Hegman Gtind: & & 1 & 1 & 1 & 1 & 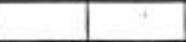 & & $2 \%$ & 3 & & \\
\hline \multicolumn{12}{|l|}{ Apparent Density. Ulbsicu. it.t } \\
\hline Bulk Dentaty, Tapoed & & 93 & 94 & 93 & 94 & & & 90 & 89 & & \\
\hline - Buk Densiny. Untapped & & $5 s$ & 57 & 55 & ss & & & so & 51 & & \\
\hline \multicolumn{12}{|l|}{ Opfical Propenties } \\
\hline Reflectance, Green Iris & & 88.0 & 300 & 880 & 45.0 & & & 850 & 89.0 & & \\
\hline Relleciance. Blue tris & & 95.0 & 320 & 870 & 82.5 & & & 83.0 & 87.0 & & \\
\hline Retleciance. Amber Tris & & 89.0 & 37.5 & 90 & 88.0 & & & 890 & 90.0 & & \\
\hline Yollowness & & 047 & 055 & 035 & $\infty 60$ & & & 060 & 033 & - & \\
\hline Erightness (457 um) & & 860 & 84.0 & $B 6.0$ & 840 & & & 84.0 & 87.0 & & \\
\hline $\mathrm{pH}$ & & 7.2 & 6.0 & 7.0 & 6.8 & & & 6.8 & 72 & 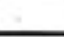 & \\
\hline \multicolumn{12}{|l|}{ Chemical Analvais. \% } \\
\hline 50 , & & 99.7 & $\infty 5$ & $\infty 9.7$ & 99.6 & & & 996 & $\infty .7$ & + & \\
\hline $\mathrm{F}_{0}, \mathrm{O}_{2}$ & & 018 & 025 & 020 & .025 & & & 025 & 020 & & \\
\hline $\mathrm{AL}_{1} \mathrm{O}$, & & 100 & 200 & .090 & 100 & & & 100 & 090 & & \\
\hline $\mathrm{no}_{\mathrm{r}}$ & & 012 & 035 & 012 & .020 & & & 020 & 012 & ${ }^{*}$ & \\
\hline $\mathrm{CeO}$ & & .01 & $<01$ & .035 & 045 & & $\because$ & 015 & .035 & & \\
\hline MgO & '. & $<01$ & $<01$ & $<01$ & $<.01$ & $\ldots$ & & $<01$ & $<01$ &. & \\
\hline LO. & & 145 & 150 & 100 & 200 & & & .200 & .140 & & \\
\hline $\begin{array}{l}\text { ASTM C. } 371.56 \\
\text { SEDGGRAPH 50\% Point ASTMC } \\
\text { Fisher Subseve ASTM B-330 } \\
\text { Oerived from fisher ang. par } \\
\text { ASTM D. } 1483\end{array}$ & 120 & coovo) & & & $\begin{array}{l}\text { U.S } \\
\text { Hun } \\
\text { Pho } \\
5 \% \\
\text { AST }\end{array}$ & $\begin{array}{l}\text { MMO } 1210 \\
\text { Silca } \\
\text { nterlab Colonmeter A } \\
\text { otovod } \\
\text { Slurry } \\
\text { MMC-146-72 }\end{array}$ & ME.306 & & & & \\
\hline
\end{tabular}


Rev. 0

Formerly BNF-003-98-0271

RPP-WTP Doc. TRPT-W375-00-00028

Chemalloy Company, Inc. P.O. Box 350 Bryn Mawr, PA 19010-0350

Tel. No. $610-527-3700$ Fax No. 610-527-3878

\title{
कि Chemalloy
}

\author{
"Over a Quarter Century \\ of Quality and Service" \\ January 1, 1999
}

Rutile

(Premium Grade - Rutile Ore)

Chemical Analysis

$\mathrm{TiO}_{2}$
$\mathrm{SiO}_{2}$
$\mathrm{zrO}_{2} *$
$\mathrm{Fe}_{2} \mathrm{O}_{3} *$
$\mathrm{~V}_{2} \mathrm{O}_{5}$
$\mathrm{Cr}_{2} \mathrm{O}_{3}$
$\mathrm{~s}$
$\mathrm{P}$

$\frac{\text { Epecification }}{94.08 \text { min. }}$

$1.5 \% \max$.

$1.5 \% \max$.

$1.08 \max$.

$1.0 \%$ max.

0.58 max.

$0.02 \% \max$.

$0.02 \% \max$.

*Airfloated product is $2.5 \% \max$.

$\frac{\text { Typical }}{958-968}$
0.558
$0.6 \%$
0.68
0.58
$0.18 \%$
$0.01 \%$
0.0158

Phveical Description

$\frac{30 \times 200 \mathrm{Mesh}}{100 \% \text { minus } 30 \text { Mesh }}$
$15 \%$ max. minus $200 \mathrm{Mesh}$
$60 \times 200$ Mesh
1008 minus 50 Mesh
18 max. On 60 Mesh
$15 \%$ max. minus 200 Mesh

$\frac{40 \times 200 \text { Mesh }}{1008 \text { minus } 40 \text { Mesh }}$
$15 \%$ max. minus 200 Mesh
$\frac{\text { Airfloated }}{1008 \text { minus } 80 \text { Mesh }}$
908 min. minus 325 Mesh

Price Schedule

PLEASE CHECK BRYN MAWR OFTICE FOR CURRENT PRICB

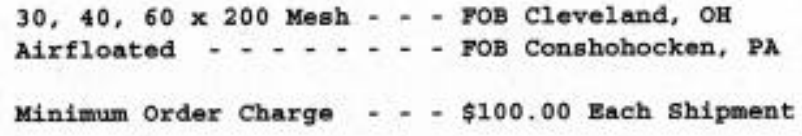

HMrs No.: 1*-0-0-E

CAS No, : 13463-67-7

Revision No.: 45

Supersedes: $9 / 1 / 98$

Page 58 


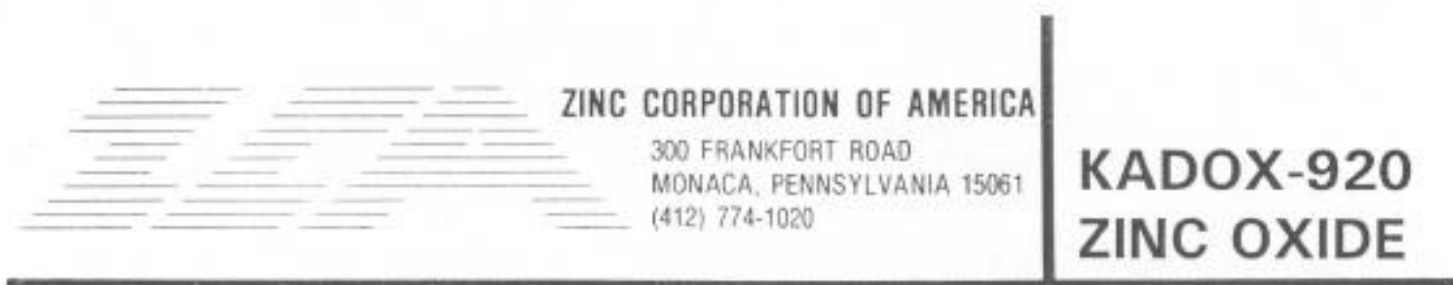

\section{DESCRIPTION}

KADOX-920 is a high purity French Process zinc oxide, providing a surface area and reactivity between KADOX-911 and KADOX-930. KADOX-920 is also available in coated (KADOX-920C), pelleted (KADOX-920P), and granular (KADOX-920G) forms.

\section{USES}

RUBBER - KADOX-920 is used extensively in various rubber products, such as mechanical goods, insulated wire, footwear, and tires, where uniform activation, moderate reinforcement, and good dispersion are desired.

OTHER USES - KADOX-920 is used in the production of ceramics, rayon, resinates, textiles, zinc chromates, and phosphate solutions where a zinc oxide of high purity is required.

\section{TECHNICAL DATA}

Representative Physical Properties

Mean Particle Size (microns) ....... 0.21

Surface Area (sq. meters/gram) ..... 5.0

Specific Gravity ................. 5,6

Apparent Density (lb./ft. ${ }^{3}$ ) $\ldots . . . \ldots . . .35$.

Through 325 Mesh ................ 99.99\%

Specifications ..................ASTM D-79
Representative Chemical Properties

Zno ............. 99.8\%

Pbo $\ldots . . . . . . . . . . .001 \%$

Cdo $\ldots . . . . . . . . . .005 \%$

$\mathrm{CuO} \ldots \ldots \ldots \ldots \ldots<.0005 \%$

$\mathrm{MnO} . . . . . . . . . . .<<.0005 \%$

$\mathrm{Fe}_{2} \mathrm{O}_{3} \ldots \ldots \ldots \ldots \ldots . . .001 \%$

$\mathrm{H}_{2} \mathrm{O}$ Soluble Salts ... . .02\% 
Rev. 0

Formerly BNF-003-98-0271

RPP-WTP Doc. TRPT-W375-00-00028

\author{
Cyprus Eoote Mineraf Company \\ Silvec Paak Operations, Hwy.285 \\ Siver Peak, Nevada 8904T \\ (702) 937.2202 \\ FAX $(7024) 937-2250$
}

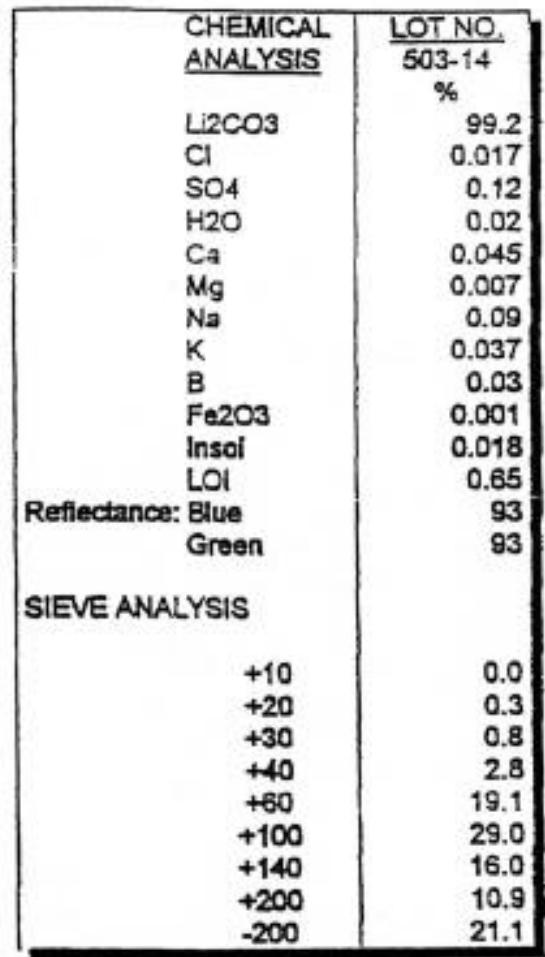

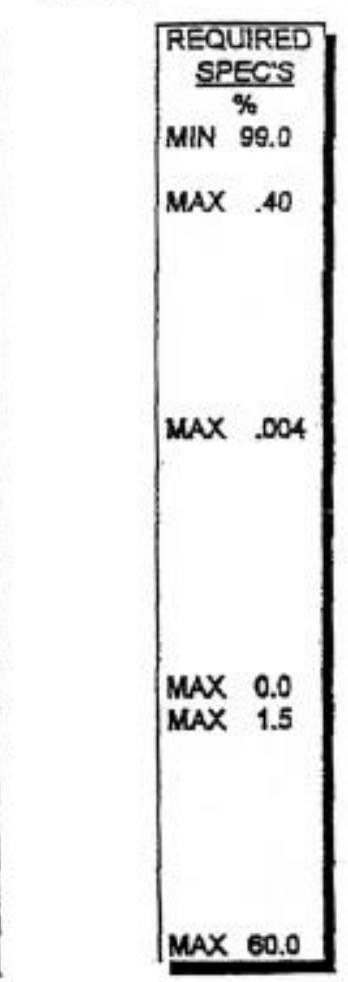

WECERTIFY THATT THIS

LOT MEEISTHEMINIMUM

REQUIREMENTS FOR SP01000. Rev 1.

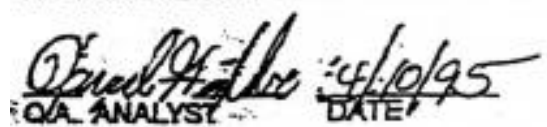

FOR SHIPPINGUSEONLY
CUSTOMER RAY SCHUIMACHER
CUSTOMER PO\# VERBAL
CUSTOMER CODE\#:
CFM ORDER 1003490

FOOTE

imtrus

CERTIFICATE of ANALYSIS

UTHIUM CARBONATE

(CRYSTAL)

ANALYSIS

DATE: 
Rev. 0

Formerly BNF-003-98-0271

RPP-WTP Doc. TRPT-W375-00-00028

(ด)

American Minerals, Inc.

901 E. Eighth Avenue, Suite \#200

King of Prussia, Pennsylvania 19406

\section{ZIRCON}

Zirconium Silicate

Zircon Sand and Flour for all applications. Large stockpiles maintained assuring consistent high quality and reliable supply of different grades and grinds for various industries.

\begin{tabular}{ll}
\hline APPLICATIONS & \\
& - Reel \\
& - Foundries \\
& - Ceramics \\
& - Chemical \\
- Abrasive
\end{tabular}

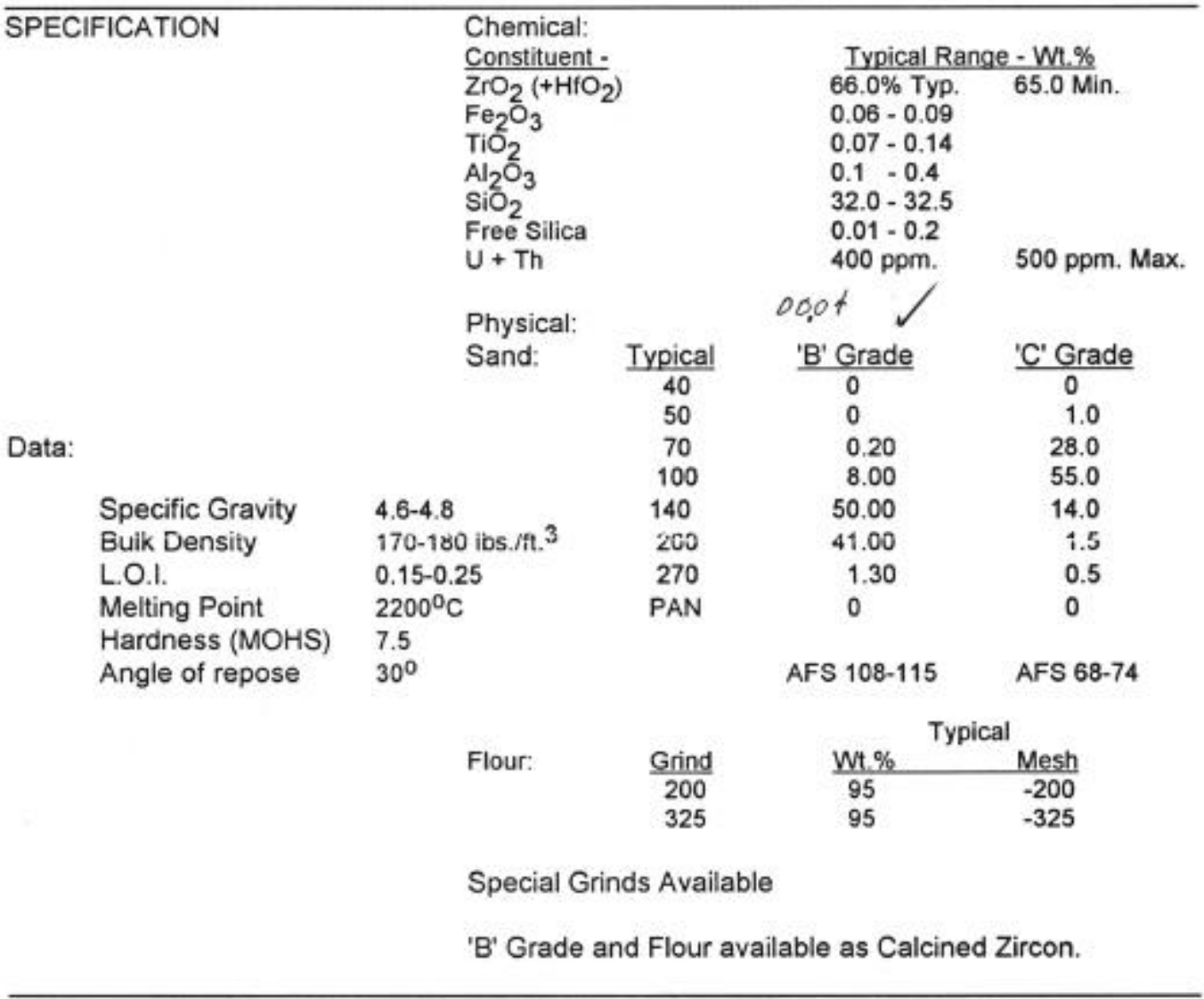

Tel. (610) 962-5050 - Fax (610) 962-5056 - Telex 881075 